\author{
UNIVERZA V LJUBLJANI
}

FAKULTETA ZA MATEMATIKO IN FIZIKO

FAKULTETA ZA RAČUNALNIŠTVO IN INFORMATIKO

Nejc Vesel

\title{
Staranje obrazov s pomočjo globokih generativnih nevronskih mrež
}

\author{
MAGISTRSKO DELO \\ INTERDISCIPLINARNI MAGISTRSKI PROGRAM DRUGE \\ STOPNJE \\ RAČUNALNIŠTVO IN MATEMATIKA
}

Mentor: izr. prof. dr. Peter Peer

Somentor: izr. prof. dr. Vitomir Štruc, as. Blaž Meden

Ljubljana, 2018 


\section{ZAHVALA}

Rad bi se zahvalil mentorju dr. Petru Peeru za vso pomoč in nasvete pri pisanju naloge. Prav tako, bi se rad zahvalil doktorskemu študentu Blažu Medenu za vse praktične nasvete glede implementacije ter stalno pripravljenost odgovarjati na moja vprašanja.

Poleg tega pa bi se rad zahvalil tudi svojim staršem za vso podporo v času študija.

Nejc Vesel, 2018 


\section{Kazalo}

Program dela

$\begin{array}{ll}\text { Povzetek } & \text { ix }\end{array}$

Abstract $\quad$ xi

1 Uvod 1

1.1 Motivacija ......................... 1

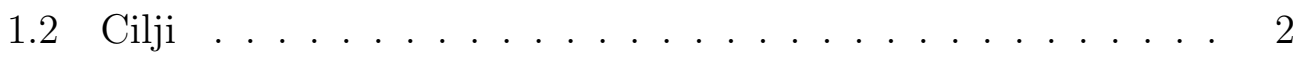

1.3 Struktura ..................... . . 2

2 Pregled področja $\quad 5$

2.1 Avtoenkoder . . . . . . . . . . . . . . . 5

2.2 Generativne nasprotniške mreže . . . . . . . . . . . . . 6

2.3 Variacijski avtoenkoder . . . . . . . . . . . . . . 9

2.4 Nasprotniški avtoenkoder . . . . . . . . . . . . . . . . . 12

2.5 Staranje obrazov . . . . . . . . . . . . . . . . 14

2.5.1 Staranje z uporabo pogojnih generativnih nasprotniških mrež . . . . . . . . . . . . . . . . 15

2.5.2 Staranje z uporabo povratnih nevronskih mrež . . . . . 18

2.5.3 Staranje s pogojnim nasprotniškim avtoenkoderjem . . 18

3 Implementacija $\quad 21$

3.1 Pogojna generativna nasprotniška mreža . . . . . . . . . . . 21

3.1.1 Teoretično ozadje . . . . . . . . . . . . . . 21 
3.1 .2 Implementacija . . . . . . . . . . . . . . 22

3.2 Pogojni Wasserstein GAN . . . . . . . . . . . . . . 23

3.2.1 Teoretično ozadje . . . . . . . . . . . . . 23

3.2 .2 Implementacija . . . . . . . . . . . . . . . . 25

3.3 BICOGAN . . . . . . . . . . . . . . . . . 27

3.3 .1 Teoretično ozadje . . . . . . . . . . . . . 27

3.3.2 Implementacija . . . . . . . . . . . . . . . . . . . 28

3.4 Variacijski avtoenkoder . . . . . . . . . . . . . . . . . . 29

3.4.1 Teoretično ozadje . . . . . . . . . . . . . . 29

3.4 .2 Implementacija . . . . . . . . . . . . . . . . . 29

3.5 Avtoenkoder . . . . . . . . . . . . . . . . . 43

3.5.1 Teoretično ozadje . . . . . . . . . . . . . 43

3.5.2 Implementacija . . . . . . . . . . . . . . . . . 44

3.5.3 Dodatna optimizacija . . . . . . . . . . . . . . . . . 47

4 Rezultati $\quad 51$

4.1 Podatkovna baza ter eksperimentalni protokol . . . . . . . . . 51

4.2 Vmesni rezultati . . . . . . . . . . . . . . . . 53

4.2.1 Pogojna generativna mreža . . . . . . . . . . . 53

4.2.2 Pogojni Wasserstein GAN . . . . . . . . . . . 55

4.2 .3 BICOGAN . . . . . . . . . . . 58

4.2.4 Variacijski avtoenkoder . . . . . . . . . . . . . . 59

4.2 .5 Avtoenkoder . . . . . . . . . . . . . . . . 64

4.3 Metrike ................... . . 65

4.4 Evalvacija rezultatov . . . . . . . . . . . . . . . 66

$\begin{array}{lll}5 & \text { Zaključek } & 73\end{array}$

$\begin{array}{ll}\text { Literatura } & 74\end{array}$ 


\section{Program dela}

Staranje obrazov je eden izmed problemov na področju generativnega strojnega učenja. V magistrskem delu raziščite sodobne pristope $\mathrm{k}$ staranju obrazov, ki za svoje delovanje uporabljajo globoko učenje. Preglejte arhitekture nevronskih mrež uporabljenih $\mathrm{v}$ teh metodah ter poizkusite z raziskovalnim delom nadgraditi katero od teh metod. Podrobno opišite modele, ki ste jih implementirali in spoznanja do katerih ste prišli med delom. Raziščite prednosti in slabosti različnih arhitektur nevronskih mrež za ta problem. Dobljene rezultate primerjajte med sabo in z obstoječimi deli na tem področju.

\section{Osnovna literatura:}

[1] G. Antipov, M. Baccouche, J.-L. Dugelay, Face aging with conditional generative adversarial networks, in: The IEEE International conference on Image processing (ICIP), 2017, pp. 2089-2093.

[2] Z. Zhang, Y. Song, H. Qi, Age progression/regression by conditional adversarial autoencoder, in: The IEEE Conference on computer vision and pattern recognition (CVPR), 2017.

Podpis mentorja: 


\section{Seznam uporabljenih kratic}

\begin{tabular}{|c|c|c|}
\hline kratica & angleško & slovensko \\
\hline AAM & $\begin{array}{l}\text { active appearance mo- } \\
\text { del }\end{array}$ & aktivni izgledni model \\
\hline AEVB & $\begin{array}{l}\text { auto-encoding } \\
\text { variational Bayes }\end{array}$ & $\begin{array}{l}\text { samokodirni variacijski } \\
\text { Bayes }\end{array}$ \\
\hline ADAGRAD & adaptive gradient & adaptivni gradient \\
\hline BICOGAN & $\begin{array}{l}\text { bidirectional } \\
\text { conditional generative } \\
\text { adversarial network }\end{array}$ & $\begin{array}{l}\text { dvosmerna pogojna } \\
\text { generativna naspro- } \\
\text { tniška mreža }\end{array}$ \\
\hline CGAN & $\begin{array}{l}\text { conditional generative } \\
\text { adversarial network }\end{array}$ & $\begin{array}{l}\text { pogojna generativna } \\
\text { nasprotniška mreža }\end{array}$ \\
\hline COBYLA & $\begin{array}{l}\text { constrained opti- } \\
\text { mization by linear } \\
\text { approximation }\end{array}$ & $\begin{array}{l}\text { omejena optimizacija z } \\
\text { linearno aproksimacijo }\end{array}$ \\
\hline CWGAN & $\begin{array}{l}\text { conditional Wasserstein } \\
\text { generative adversarial } \\
\text { network }\end{array}$ & $\begin{array}{l}\text { pogojna Wassersteinova } \\
\text { generativna nasprotniška } \\
\text { mreža }\end{array}$ \\
\hline DFC & $\begin{array}{l}\text { deep feature } \\
\text { consistency }\end{array}$ & $\begin{array}{l}\text { konsistentne globoke } \\
\text { značilke }\end{array}$ \\
\hline FN & false negative & napačno negativen \\
\hline FP & false positive & napačno pozitiven \\
\hline
\end{tabular}




\begin{tabular}{|c|c|c|}
\hline GAN & $\begin{array}{l}\text { generative adversarial } \\
\text { network }\end{array}$ & $\begin{array}{l}\text { generativna naspro- } \\
\text { tniška mreža }\end{array}$ \\
\hline GRU & gated recurrent unit & povratna enota $\mathrm{z}$ vrati \\
\hline IMDB & internet movie database & $\begin{array}{l}\text { spletna podatkovna } \\
\text { baza filmov }\end{array}$ \\
\hline L-BFGS-B & $\begin{array}{l}\text { Limited-memory } \\
\text { Broyden - Fletcher } \\
\text { - Goldfarb - Shanno } \\
\text { (Box) algorithm }\end{array}$ & $\begin{array}{l}\text { Broyden }- \text { Fletcher } \\
- \text { Goldfarb - Shanno } \\
\text { algoritem z omeje- } \\
\text { nim pomnilnikom in } \\
\text { škatlastimi omejitvami }\end{array}$ \\
\hline ReLU & rectified linear unit & $\begin{array}{l}\text { usmerjena linearna } \\
\text { enota }\end{array}$ \\
\hline TN & true negative & resnično negativen \\
\hline TP & true positive & resnično pozitiven \\
\hline TV & total variation & skupna varianca \\
\hline SGD & $\begin{array}{l}\text { stochastic gradient de- } \\
\text { scent }\end{array}$ & $\begin{array}{l}\text { stohastični gradientni } \\
\text { spust }\end{array}$ \\
\hline VAE & variational autoencoder & variacijski autoenkoder \\
\hline WGAN & $\begin{array}{l}\text { Wasserstein generative } \\
\text { adversarial network }\end{array}$ & $\begin{array}{l}\text { Wassersteinova } \\
\text { generativna naspro- } \\
\text { tniška mreža }\end{array}$ \\
\hline
\end{tabular}




\section{Povzetek}

Naslov: Staranje obrazov s pomočjo globokih generativnih nevronskih mrež

Staranje obrazov je področje, ki se ukvarja z modeliranjem staranja osebe iz ene same referenčne slike. Želimo ustvariti generativni model, ki nam s pomočjo nevronskih mrež ustvari slike referenčne osebe pri različnih starostnih skupinah. Pri našem pristopu smo želeli cilj doseči z uporabo različnih generativnih arhitektur. Preizkusili smo nekaj uveljavljenih pristopov ter implementirali nekaj lastnih idej, ki se niso izkazale za najuspešnejše. Dobljeni končni rezultati so bili pod pričakovanji, vendar naloga naredi pregled nad preizkušenimi pristopi in njihovo implementacijo. Naloga predstavlja dobro podlago za nadaljnje raziskovanje na tem področju, saj naredi pregled nad uspešnimi in neuspešnimi pristopi ter težavami, ki se pojavljajo pri raziskovanju tega področja.

\section{Ključne besede}

staranje obrazov, variacijski avtoenkoder, generativne mreže, nevronske mreže, generativne nasprotniške mreže, nasprotniški avtoenkoder 


\section{Abstract}

Title: Face aging using generative neural networks

Face aging as a research topic is dealing with modelling human aging from a reference photo. We want a generative model that, using generative neural networks, generates images of a reference person at a different age. We implemented some existing approaches and developed some of our own, however, they didn't return results that we wished for. The final results were below expectations, however, the thesis makes a good overview over the implemented approaches and their implementation. The thesis creates a good foundation for further research. It gives a good overview over successful and non successful approaches and the difficulties that arise when doing research on this topic.

\section{Keywords}

face aging, variational autoencoder, generative networks, neural networks, generative adverserial networks, adverserial autoencoders 


\section{Poglavje 1}

\section{Uvod}

\subsection{Motivacija}

Staranje obrazov je podpodročje splošnega generiranja obrazov z določenim dodatnim pogojem, da je med generiranimi slikami potrebno obdržati identiteto. Področje je staro že kar nekaj časa, vendar je z razmahom globokega učenja in nevronskih mrež dobilo nov zagon. Metode globoke učenja nam omogočajo razvoj algoritmov staranja, kjer je dovolj imeti podatkovno bazo oseb različnih starosti. Uporabnost metode je večplastna. Ena od glavnih motivacij je izboljšanje sistemov za razpoznavo obrazov. Človeški obraz se namreč z leti včasih močno spremeni. Če nam uspe modelirati učinke staranja in pomlajevanja, lahko uporabimo to znanje, da naše metode prepoznavanja obrazov naredimo robustnejše na spremembe v starosti osebe. To lahko uporabljamo v forenziki, kjer lahko lažje določimo izgled zločincev, ki so iskani že več let.

Ena od dodatnih motivacij je tudi področje iskanja pogrešanih oseb. Podobno kot pri lovljenju ubežnikov, želimo iz stare obrazne slike predvideti trenutni izgled osebe, tako da upoštevamo spremembe obraznih potez zaradi staranja. Te slike se lahko nato javno objavi, kot referenco za trenutni izgled osebe, kar omogoča lažje iskanje.

Druga večja uporaba je v zabavni in lepotni industriji. Obstaja veliko 
spletnih strani in aplikacij [3, 4], ki ponujajo staranje obraza. Omenjeni aplikaciji smo tudi preizkusili, vendar ne omogočajo izbire ciljnih let, saj osebo vedno postarajo do starosti večje od šestdeset let. Zanimiva je aplikacija [5], ki združuje staranje obrazov in spreminjanje indeksa telesne mase (BMI). Ta aplikacija se prodaja zavarovalnicam, podjetjem, zdravnikom, ki želijo motivirati ljudi v bolj zdrave prehranjevalne navade. Za razliko od prejšnjih dveh, imamo tukaj možnost nastavljanja točne začetne in ciljne starosti. Pomembno je omeniti, da večina teh aplikacij deluje s pomočjo transformacij in dodajanjem tekstur na sliko. Znotraj tega pristopa se naravno spreminjanje kostne strukture obraza, ki je posledica staranja, ne upošteva, kar pomeni manjšo prediktivno moč.

\section{$1.2 \quad$ Cilji}

S pomočjo nevronskih mrež želimo razviti model, ki bi ob podani sliki in trenutni starosti vrnil generirane obrazne slike te osebe ob različnih starostih. Želimo, da bi naš model deloval na barvnih slikah, vendar se zaradi omejitev generativnih nevronskih mrež osredotočimo na manjše dimenzije, kjer vhodne ter izhodne slike na presežejo 224 slikovnih točk dolžine in širine. Želimo, da bi naš model, ko je enkrat naučen, deloval brez dodatnih parametrov, ki bi jih morali nastavljati za vsako sliko posebej. Prav tako želimo, da bi naučen model deloval dovolj hitro, da bi lahko v kratkem času postarali več obrazov.

Eden večjih problem pri postopkih staranja obrazov je težava z ohranjanjem identitete. Našo metodo želimo zasnovati na tak način, da maksimiziramo ohranjanje identitete starane osebe.

\subsection{Struktura}

V magistrski nalogi najprej v poglavju 2 naredimo pregled področja, kjer se osredotočimo na različne tipe generativnih nevronskih mrež, ki so pomembne za širše razumevanje generativnega strojnega učenja. Nato povzamemo nekaj 
člankov, ki se ukvarjajo s sodobnimi pristopi staranja obrazov. Pogledamo si tudi nekaj starejših pristopov, ki so se uporabljali pred razmahom globokega učenja. Nato sledi poglavje 3, kjer podrobneje opišemo vse implementirane modele. Dotaknemo se njihove arhitekture, uporabljenih parametrov ter težav v implementaciji in delovanju, na katere smo naleteli med delom. V poglavju 4 predstavimo uporabljene podatkovne baze, vmesne rezultate, ki smo jih dobili z implementacijo modelov ter predstavimo končne rezultate. Te evalviramo s pomočjo ankete in rezultate predstavimo in primerjamo s sorodnimi deli. 
1. UVOD 


\section{Poglavje 2}

\section{Pregled področja}

V nadaljevanju predstavimo nekaj osnovnih modelov iz področja generativnih nevronskih mrež, katerih poznavanje je osnova za nadaljnje branje. Prav tako si pogledamo nekaj referenčnih objav iz področja staranja obrazov, kjer predstavimo nakatere modernejše pristope ter se dotaknemo starejših metod.

\subsection{Avtoenkoder}

Ena od glavnih arhitektur na področju generativnih modelov je avtoenkoder. Avtoenkoderji so sestavljeni iz dveh glavnih delov, enkoderja $E$ in dekoderja $D$. Cilj enkoderja je stisniti vhodne podatke v latentno (skrito) reprezentacijo manjše dimenzije, cilj dekoderja pa je iz latente reprezentacije rekonstruirati vhodne podatke. Želimo torej:

$$
E(x)=y \text { in } D(y) \approx x .
$$

Grafično lahko strukturo vidimo na sliki 2.1.

V splošnem se bo v procesu kodiranja in odkodiranja vedno zgodila izguba informacij, saj je latentni prostor manjše dimenzije kot vhodni podatek. Na primer, sliko velikost $28 \times 28$ točk stisnemo v vektor velikosti $10 \times 1$.

Nevronsko mrežo učimo z željo, da je rekonstruiran podatek čim bolj podoben vhodnemu. Na prvi pogled se zdi, da je uporabnost avtoenkoder- 


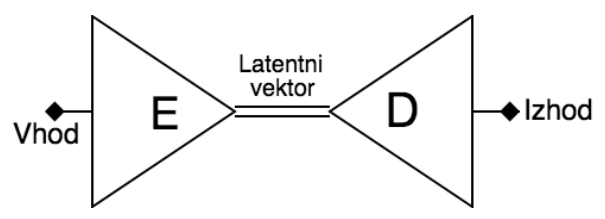

Slika 2.1: Idejna shema oblike avtoenkoderja.

jev omejena na kompresijo podatkov, vendar obstaja velika uporabnost na področju generativnih modelov $[6,7,8]$. Ker je latentni prostor manjše dimenzije, prisilimo mrežo, da v latentni prostor zakodira čim več informacije in tako ohrani najpomembnejše značilke na slikah.

$\mathrm{V}$ praksi je to koristno za namene razšumljanja slik in zapolnjevanja nepopolnih delov slik [6]. V teh primerih mrežo naučimo, da iz nepopolnih (manjkajočih, šumnatih) slik generira čiste slike.

V najbolj enostavni obliki je avtoenkoder sestavljen iz treh slojev. Vhodni sloj je polno povezan z edinim skritim slojem, ki je nato polno povezan z izhodnim slojem. V praksi je najpogostejša izboljšava osnovne arhitekture oblika z več polnopovezanimi skritimi sloji, ki se zmanjšujejo v velikosti na strani enkoderja in povečujejo na strani dekoderja. Če delamo s podatki kot so slike, lahko polnopovezane sloje zamenjamo s konvolucijskimi sloji različnih dimenzij.

Dimenzije skritih slojev in latentnega vektorja so odvisne od dimenzij vhodnih podatkov ter od tipa podatkov, s katerimi delamo. Parametri modela morajo biti prilagojeni našim podatkom in cilju, ki ga želimo doseči.

\subsection{Generativne nasprotniške mreže}

Generativne nasprotniške mreže so bile prvič predstavljene v članku [9], kjer je predstavljen algoritem tudi podkrepljen s teoretičnimi dokazi. Glavna ideja algoritma je, da pomerimo generativni model proti nasprotniku, ki določa ali je generiran rezultat podoben tistemu, ki ga želimo modelirati. Predstavljamo si lahko bitko med ponarejevalcem denarja in strokovnjakom, ki določa ali je kos denarja pristen. Želimo, da oba akterja skozi iterativni 


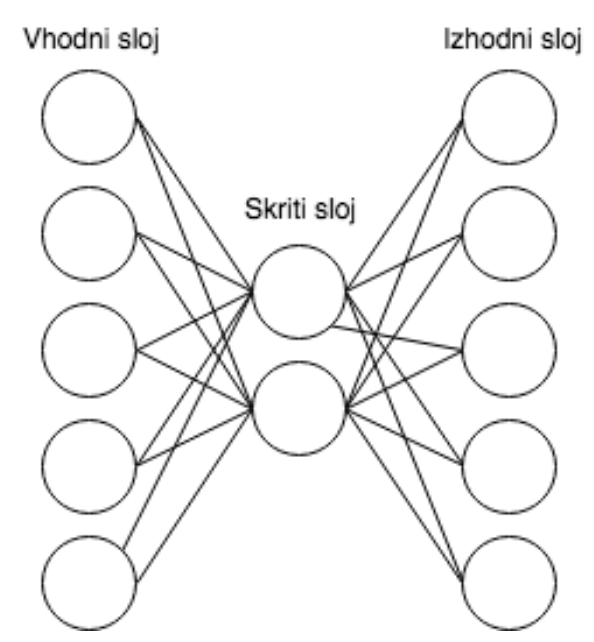

Slika 2.2: Diagram najenostavnejšega avtoenkoderja.

nasprotniški proces izboljšujeta drug drugega.

Idejno shemo mreže lahko vidimo na sliki 2.3. To lahko primerjamo s shemo avtoenkoderja 2.1 in razlike v arhitekturi so očitne.

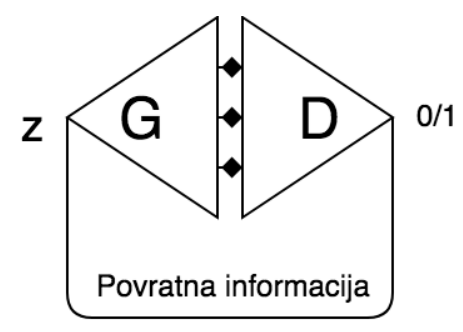

Slika 2.3: Generator na vhod dobi šum $z$ iz katerega generira rezultat, diskriminator pa pove ali misli, da je slika iz učne množice ali ne.

Rečemo, da sta tako diskriminator kot generator večslojni nevronski mreži. Matematično gledano želimo naučiti generator $G$, da bo proizvajal vzorce, katerih porazdelitev je podobna porazdelitvi podatkov, katere želimo modelirati. Da bi se naučili porazdelitev generatorja $p_{g}$ na podatkih $x$, definiramo priorno porazdelitev $p_{g}(z)$, kjer $z$ predstavlja vektor šuma.

Preslikavo v prostor podatkov predstavimo z $G\left(z ; \theta_{g}\right)$, kjer je G odvedljiva funkcija, ki jo predstavlja večslojna nevronska mreža in $\theta_{g}$ njeni parametri. Prav tako definiramo $D\left(x ; \theta_{d}\right)$, katerega izhod je skalar $D(x)$, ki predstavlja 
verjetnost, da je $x$ prišel iz podatkov in ne iz $p_{g}$ (torej ni bil generiran s pomočjo generatorja). Hočemo torej, da diskriminator za vhod vedno pravilno določi ali je prišel iz množice realnih podatkov oz. ali je bil generiran s pomočjo generatorja $G$. To zapišemo kot:

$$
\min _{G} \max _{D} V(D, G)=\mathbb{E}_{x \sim p_{\text {data }}(x)}[\log D(x)]+\mathbb{E}_{z \sim p_{z}(z)}[\log (1-D(G(z)))] .
$$

Formula je natančneje izpeljana v [9]. Psevdokoda algoritma, ki uporablja gradientni spust za implementacijo našega generativnega nasprotniškega modela, je sledeča:

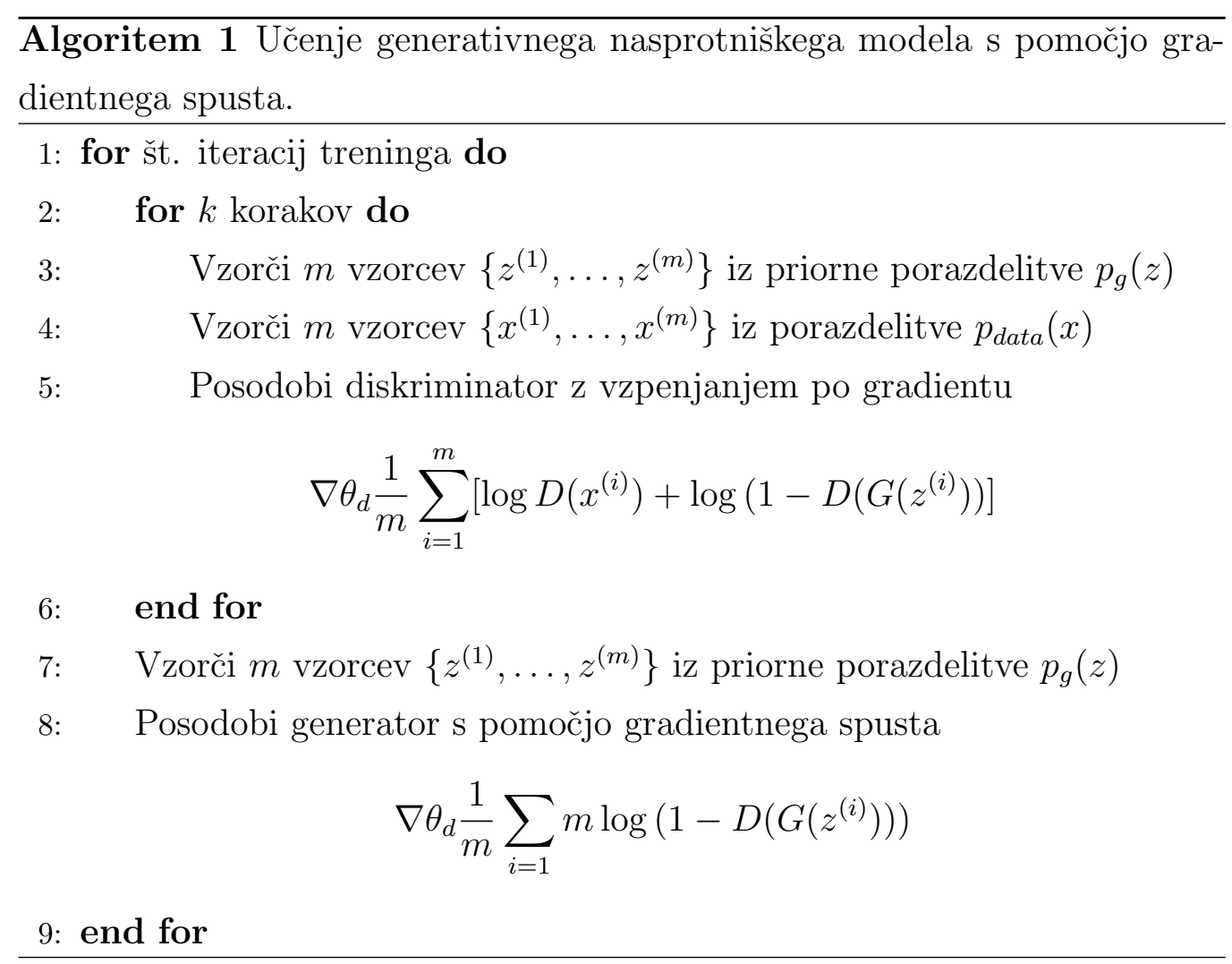

Parameter $k$ za število iteracij notranje zanke določimo glede na eksperimentalno evalvacijo delovanja. Pove nam kolikokrat naredimo korak optimizacije diskriminatorja za vsak korak generatorja. Želimo, da generator in diskriminator ostajata $\mathrm{v}$ ravnovesju. Če eden od njiju postane preveč učinkovit, težko pride do nadaljnjega izboljšanja v kvaliteti rezultatov, kar 
je tudi ena glavnih slabosti tega pristopa. Na začetku učenja, ko je G slab, se v praksi lahko zgodi, da $D$ z lahkoto zavrne vse generirane vzorce, saj so očitno različni od podatkov iz učne množice. V tem primeru se vrednost $\log (1-D(G(z)))$ močno poveča in težko najdemo globalni minimum. Da se izognemo temu problemu, reformuliramo problem tako, da namesto minimizacije $\log (1-D(G(z)))$ učimo $G$, da maksimizira $\log D(G(z))$. To nam omogoča, da na začetku učenja dobimo močnejše gradiente, ki omogočajo boljše premike $\mathrm{v}$ smer optimalne rešitve.

Ena od možnih razširitev omenjenih v članku [9] je razširitev na pogojni generativni model $p(x \mid c)$, kar dobimo tako, da dodamo pogoj $c$ na vhod tako generatorju kot diskriminatorju.

\subsection{Variacijski avtoenkoder}

Eden od glavnih pristopov pri generativnem strojnem učenju je uporaba variacijskih avtoenkoderjev [10]. Ti so posplošitev avtoenkoderja, kjer enkoder pogojimo tako, da ustvarjeni latentni vektorji okvirno sledijo normalni porazdelitvi. Generiranje novih slik je torej samo vzorčenje iz normalne porazdelitve $\mathrm{z}$ določeno srednjo vrednostjo in standardno deviacijo, ki jo dobimo iz mreže. Vedno je potreben kompromis med rekonstrukcijsko napako in prileganjem normalni porazdelitvi. Statistično gledano imamo spremenljivko $z$, katera generira $x$. Izračunali bi radi $p(z \mid x)=\frac{p(x \mid z) p(z)}{p(x)}$. Izkaže se, da je izračun te porazdelitve $\mathrm{v}$ praksi problematičen, zato aproksimiramo to porazdelitev s porazdelitvijo $q(z \mid x)$, ki ji je podobna in jo znamo izračunati. Za mero podobnosti med dvema porazdelitvama pa uporabimo Kullback Leibler (KL) divergenco [11]. V naslednjem delu predstavimo bolj natančno in formalno izpeljavo variacijskega avtoenkoderja.

Predstavljajmo si množico $X=\left\{x^{(i)}\right\}_{i=n}^{N}$, ki vsebuje $N$ neodvisnih in enakomerno porazdaljenih slučajnih spremenljivk $x$. Predpostavimo, da so podatki generirani s pomočjo nekega naključnega procesa, ki vključuje slučajno spremenljivko $z$, ki pa je ne vidimo. 
Ta proces je sestavljen iz dveh korakov:

1. Vrednost $z^{(i)}$ je generirana iz predhodne porazdelitve $p_{\theta^{*}}(z)$.

2. Vrednost $x^{i}$ je generirana iz pogojne porazdelitve $p_{\theta^{*}}(x \mid z)$.

Predpostavimo, da $p_{\theta^{*}}(z)$ in $p_{\theta^{*}}(x \mid z)$ prihajata iz družine porazdelitev $p_{\theta}(z)$ in $p_{\theta}(x \mid z)$ in da je njihova gostota verjetnosti povsod odvedljiva glede na parametra $\theta$ in $z$. $\mathrm{V}$ praksi so vrednosti $z^{(i)}$ ter vrednost $\theta^{*}$ neznane.

Zanima nas rešitev, ki deluje tudi v primeru večje podatkovne množice ter kadar je integral marginalne verjetnosti $p_{\theta}(x)=\int p_{\theta}(z) p_{\theta}(x \mid z) d z$ neobvladljiv (ne moremo ga integrirati oz. izračunati) in kjer je posteriorna gostota $p_{\theta}(z \mid x)=p_{\theta}(z \mid x) p_{\theta}(z) / p_{\theta}(x)$ neobvladljiva. Ta dva primera se velikokrat pojavljata prav v nevronskih mrežah z nelinearnimi skritimi sloji.

Pristop z variacijskimi avtoenkoderji nam omogoča učinkovito ocenjevanje parametrov $\theta$, kar nam omogoča generiranje umetnih podatkov, ki so podobni naravnim. Kadar imamo neko vrednost $x$ ter izbrane parametre $\theta$, nam VAE omogoča dobiti aproksimacijo latentne spremenljivke $z$. To se uporablja $\mathrm{v}$ namene kodiranja, kjer informacije iz $x$ zakodiramo $\mathrm{v} z$. Še ena od uporabnih lastnosti pa je aproksimiranje inference spremenljivke $x$, kar nam omogoča uporabo v smeri razšumljanja (angl. denoising) ter pri napolnitvi prekritih delov slik (angl. inpainting).

Uvedemo prepoznavni model $q_{\phi}(z \mid x)$, ki je aproksimacija $p_{\theta}(z \mid x)$. Izpeljali bomo metodo, ki se $\phi$ nauči skupaj s parametri $\theta$. Neopazovano spremenljivko $z$ si lahko predstavljamo kot zakodirano informacijo. Zato model $q_{\phi}(z \mid x)$ imenujemo enkoder, saj nam glede na podatek $x$ izračuna porazdelitev možnosti $z$, ki bi lahko generirale ta podatek. Analogno bomo $p_{\theta}(x \mid z)$ imenovali dekoder, saj nam iz z producira porazdelitev čez vrednosti $x$.

Izpeljemo lahko spodnjo mejo:

$$
\mathcal{L}\left(\theta, \phi, x^{(i)}\right)=-D_{K L}\left(q_{\phi}\left(z \mid x^{(i)}\right) \| p_{\theta}(z)\right)+\mathbb{E}_{q \phi\left(z \mid x^{(i)}\right)}\left[\log p_{\theta}\left(x^{(i)} \mid z\right)\right],
$$

ki jo želimo optimizirati glede na parametre $\phi$ in $\theta$. Zaradi velike variance gradienta je naivna Monte Carlo metoda [12], za ta primer neučinkovita in potrebujemo boljšo metodo. 
Zanima nas cenilka za spodnjo mejo $\mathcal{L}$ in za njene odvode. Upoštevajoč nekaj pogojev, ki so bolj natančno razloženi v [10], lahko reparametriziramo $\tilde{z} \sim q_{\phi}(z \mid x) \mathrm{z}$ odvedljivo preslikavo šuma $\epsilon$, torej $\tilde{z}=g_{\phi}(\epsilon, x)$, kjer velja $\epsilon \sim p(\epsilon)$. Sedaj lahko vpeljemo Monte Carlo aproksimacijo za pričakovano vrednost neke funkcije $f(z)$, glede na $q_{\phi}(z \mid x)$ kot:

$$
\mathbb{E}_{q_{\phi}\left(z \mid x^{(i)}\right)}[f(z)]=\mathbb{E}_{p(\epsilon)}\left[f\left(g_{\phi}\left(\epsilon, x^{(i)}\right)\right)\right] \simeq \frac{1}{L} \sum_{l=1}^{L} f\left(g_{\phi}\left(\epsilon^{(l)}, x^{(i)}\right)\right),
$$

kjer je $\epsilon^{(l)} \sim p(\epsilon)$.

To tehniko apliciramo na naš problem in dobimo cenilko $\tilde{\mathcal{L}}^{A}\left(\theta, \phi ; x^{(i)}\right) \simeq$ $\mathcal{L}\left(\theta, \phi ; x^{(i)}\right)$ za katero velja:

$$
\tilde{\mathcal{L}}^{A}\left(\theta, \phi ; x^{(i)}\right)=\frac{1}{L} \sum_{l=1}^{L} \log p_{\theta}\left(x^{(i)}, z^{(i, l)}\right)-\log q_{\phi}\left(z^{(i, l)} \mid x^{(i)}\right),
$$

kjer

$$
z^{(i, l)}=g_{\theta}\left(\epsilon^{(i, l)}, x^{(i)}\right) \text { in } \epsilon^{(l)} \sim p(\epsilon) .
$$

Velikokrat lahko KL divergenco integriramo analitično, tako da je ocena z vzorčenjem potrebna le za rekonstrukcijsko napako $\mathbb{E}_{q \phi\left(z \mid x^{(i)}\right)}\left[\log p_{\theta}\left(x^{(i)} \mid z\right)\right]$. KL divergenco si lahko predstavljamo kot regularizacijski člen $\phi$, kar nam da drugo različico cenilke $\widetilde{\mathcal{L}}^{B}\left(\theta, \phi ; x^{(i)}\right) \simeq \mathcal{L}\left(\theta, \phi ; x^{(i)}\right)$, ki je definirana kot:

$$
\widetilde{\mathcal{L}}^{B}\left(\theta, \phi ; x^{(i)}\right)=-D_{K L}\left(q_{\phi}\left(z \mid x^{(i)}\right)|| p_{\theta}(z)\right)+\frac{1}{L} \sum_{l=1}^{L}\left[\log p_{\theta}\left(x^{(i)} \mid z^{(i, l)}\right)\right],
$$

in velja:

$$
z^{(i, l)}=g_{\phi}\left(\epsilon^{(i, l)}, x^{(i)}\right) \text { in } \epsilon^{(l)} \sim p(\epsilon) .
$$

Če iz podatkovne množice $X$ z $N$ elementi vzorčimo po $M$ vzorcev, lahko skonstruiramo cenilko osnovano na minisvežnjih:

$$
\mathcal{L}(\theta, \phi ; X) \simeq \widetilde{\mathcal{L}}\left(\theta, \phi ; X^{M}\right)=\frac{N}{M} \sum_{i=1}^{M} \widetilde{\mathcal{L}}\left(\theta, \omega ; x^{(i)}\right) .
$$

Minisveženj $X^{M}=\left\{x^{(i)}\right\}_{i=1}^{M}$ je naključno izbran vzorec velikosti $M$ iz množice $X$. V psevdokodi je algoritem predstavljen kot 


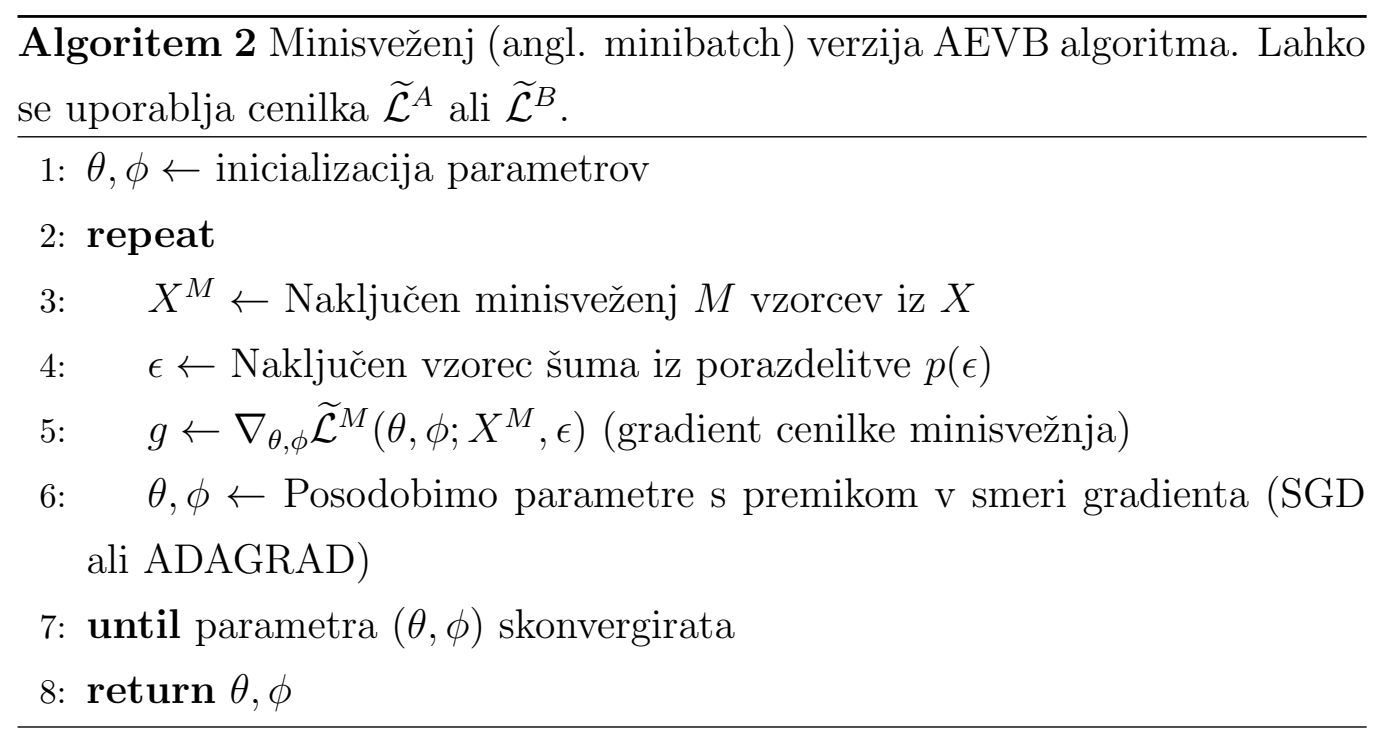

\subsection{Nasprotniški avtoenkoder}

Nasprotniški avtoenkoderji [13] so razširitev avtoenkoderjev in so po svoji zasnovi precej podobni variacijskim avtoenkoderjem. Glavna razlika se pojavi v načinu zagotavljanja porazdelitve latentnega vektorja. Variacijski avtoenkoder uporablja KL divergenco kot vodilo za vodenje pravilne porazdelitve, medtem ko se pri nasprotniških avtoenkoderjih za to koristi nasprotniško učenje, kjer želimo s pomočjo diskriminatorja doseči isti cilj.

Naj bo $x$ vhodni podatek, $z$ latentni vektor avtoenkoderja in $p(z)$ porazdelitev, kateri želimo, da koda $z$ sledi. Definirajmo $q(z \mid x)$ kot porazdelitev enkoderja, $p(x \mid z)$ kot porazdelitev dekoderja, $p_{d}(x)$ kot porazdelitev podatkov ter $p(x)$ kot porazdelitev našega modela. Enkoder definira porazdelitev $q(z)$ na latentnem vektorju kot:

$$
q(z)=\int_{x} q(z \mid x) p_{d}(x) d x .
$$

Nasprotniški avtoenkoder je avtoenkoder, ki je regulariziran z ujemanjem med $q(z)$ in $p(z)$. Nasprotniška mreža je zadolžena za vodenje porazdelitve $q(z)$ proti $p(z)$, medtem ko je avtoenkoder zaslužen za minimiziranje rekonstrukcijske napake. Velja, da je generator nasprotniške mreže tudi enkoder avtoenkoderja $q(z \mid x)$, ki je zadolžen, da prelisiči diskriminator, da ne loči 
med $q(z)$ in $p(z)$. Učenje vedno izvajamo v dveh delih, najprej učimo nasprotniško mrežo (diskriminator) in s tem regulariziramo porazdelitev latentnega vektorja. S tem se posodobi tudi generator mreže, ki je hkrati enkoder avtoenkoderja, tako da bolje zmede diskriminator. V drugem koraku pa učimo avtoenkoder in s tem izboljšujemo rekonstrukcijsko napako.

Možnih je nekaj različnih izbir za enkoder $q(z \mid x)$ :

- Deterministični - Predpostavimo, da je $q(z \mid x)$ deterministična funkcija $x$-a. $\mathrm{V}$ tem primeru je enkoder podoben enkoderju standardnega avtoenkoderja in edini vir stohastičnosti (nepredvidljivosti) v $q(z)$ ostane učna množica $p_{d}(x)$.

- Normalno porazdeljeni - Privzamemo, da je $q(z \mid x)$ normalna porazdelitev, katere srednja vrednost in varianca je dobljena iz enkoderja. Velja torej:

$$
z_{i} \sim \mathcal{N}\left(\mu_{i}(x), \sigma_{i}(x)\right)
$$

V tem primeru stohastičnost dobimo tako iz učne množice kot iz naključnosti naravne porazdelitve.

- Univerzalni aproksimator - To si predstavljamo kot posplošitev prejšnje možnosti. Cilj je, da $q(z \mid x)$ naučimo kot univerzalni aproksimator. Naj bo enkoder funkcija $f(x, \eta)$, ki na vhod dobi $x$ in naključni šum $\eta$ s fiksno porazdelitvijo, potem lahko vzorčimo iz katerekoli posteriorne porazdelitve $q(z \mid x)$, tako da evalviramo $f(x, \eta)$ pri različnih vzorcih $\eta$. Matematično gledano, predpostavimo, da velja $q(z \mid x, \eta)=$ $\delta(z-f(x, \eta))$ in

$q(z \mid x)=\int_{\eta} q(z \mid x, \eta) p_{\eta}(\eta) d \eta \Longrightarrow q(z)=\int_{x} \int_{\eta} q(z \mid x, \eta) p_{d}(x) p_{\eta}(\eta) d \eta d x$.

Tu je stohastičnost $\mathrm{v} q(z)$ dobljena tako iz učne množice kot iz šuma $\eta$ na vhodu enkoderja. $\mathrm{V}$ tem primeru nismo več omejeni na naravno porazdelitev, ampak si lahko izberemo kakršnokoli porazdelitev želimo, saj to določa porazdelitev šuma $\eta$. 
Nasprotniški avtoenkoder je mogoče razširiti v pogojno obliko, kjer vsem učnim vzorcem dodelimo oznako, kateremu razredu pripadajo. Na vhod diskriminatorja dodamo oznako pripadnost (angl. one-hot), ki predstavlja razred, kateremu vzorec pripada. Ko enkoder izračuna latentni vektor, združimo oznako skupaj z latentnim vektorjem in to podamo dekodirnemu delu mreže.

\subsection{Staranje obrazov}

Področje staranja obrazov je pred razmahom globokega učenja večinoma uporabljalo modelne pristope [14]. S pomočjo modeliranja strukture človeškega obraza in povezane anatomije se je želelo simulirati vplive staranja na človeški videz. Kot predpogoj potrebujemo način za modeliranje človeškega obraza in njegovih mimik. Ločimo tri glavne vrste modelov in sicer geometrične, osnovane na slikah (angl. image based), osnovane na izgledu (angl. appearancebased).

Pri geometričnih modelih ustvarimo mrežo ključnih točk na človeškem obrazu. S transformacijami nad temi točkami pa lahko simuliramo mimiko in staranje. Potrebujemo način, ki nam ob transformaciji še vedno ohrani osnovno strukturo objekta. Za to obstaja več pristopov, eden od najbolj znanih pa je predstavljen $\mathrm{v}$ [15] in se tudi uporablja na področju zaznave ključnih točk na obrazu.

Slikovno osnovani modeli se trudijo ustvariti fotorealistične obraze na podlagi drugih obraznik slik. Eden od primerov je prenos teksture iz ene slike na drugo s pomočjo procesiranja slikovnih signalov in geometričnega modeliranja [16]. Podobne tehnike osnovane na prenašanju lastnosti iz prototipnega obraza se uporabljajo za prenos osvetlitve, izraza in starosti [17].

Izgledni modeli za razliko od prejšnjih dveh uporabljajo statistično učenje za izgradnjo modela. $\mathrm{V}$ večini primerov se iz velike baze podatkov zgradi generični prototipni model. Uporablja se AAM model [18], ki ga s pomočjo učne množice naučimo statistični model obraza. Lastnosti referenčne slike nato s posebnimi metodami projiciramo na modelni obraz. To je v principu 
precej podobno modernejšim pristopom, vendar se razlikuje v metodah za doseganje tega cilja.

Za razliko od zgoraj opisanih pristopov pa modernejši pristopi uporabljajo nevronske mreže za dosego istih ciljev $[1,2,19,20]$. Z uporabo generativnih modelov želimo učenje statističnega modela staranja prepustiti nevronski mreži, ki se na osnovi večje baze fotografij oseb različnih starosti sama nauči kako poteka staranje človeškega obraza.

\subsubsection{Staranje $\mathrm{z}$ uporabo pogojnih generativnih na- sprotniških mrež}

Eden od pristopov, opisan v [1], simulira staranje s pomočjo pogojne generativne nasprotniške mreže. Glavna ideja razdeli postopek na tri dele:

1. Pogojno generativno nasprotniško mrežo naučimo generirati slike.

2. Glede na podano sliko $x$ starosti $y_{0}$, poišči latentni vektor $z^{*}$, pri katerem generator generira sliko, ki je najbolj podobna podani. Torej želimo minimizirati razliko med $x$ in $\hat{x}=G\left(z^{*}, y_{0}\right)$.

3. Staranje dosežemo tako, da generatorju ob optimalnem vektorju $z^{*}$ namesto originalne starosti podamo ciljno starost $y_{c i l j}$, torej $x_{c i l j}=$ $G\left(z^{*}, y_{c i l j}\right)$.

Zelo pomembna je informacija o arhitekturi nevronske mreže, ki nam generira slike. Tukaj se znotraj mreže uporabljajo konvolucijski sloji v generatorju in dekonvolucije $\mathrm{v}$ diskriminatorju. Za doseganje stabilnosti učenja je priporočeno upoštevanje nekaterih osnovih smernic [21]:

- Vse agregacijske (angl. pooling) sloje zamenjamo s koračnimi (angl. strided) konvolucijami v diskriminatorju in obratno koračnimi (angl. fractional strided) konvolucijami v generatorju.

- Normalizacijo svežnjev (angl. batch normalization) uporabljamo tako $\mathrm{v}$ generatorju kot $\mathrm{v}$ diskriminatorju. 
- Pri bolj globokih arhitekturah ne smemo uporabljati polno povezanih slojev.

- V generatorju uporabljamo aktivacijo z usmerjeno linearno enoto (angl. ReLU) v vseh slojih, razen v zadnjem.

- V diskriminatorju za vse sloje uporabljamo aktivacijo s puščajočo usmerjeno linearno enoto (angl. Leaky ReLU).

V tem primeru generator na vhod sprejme vektor šuma $z$ dimenzije $100 \times 1$. Nato ga s pomočjo polnopovezanega sloja in preoblikovanja razširi na dimenzijo $1024 \times 4 \times 4$, katero nato s pomočjo zaporedja obratno koračnih kovolucij spremenimo v dimenzijo slike, ki je $64 \times 64 \times 3$. To je najbolje vidno na sliki 2.4, ki nazorno prikaže arhitekturo.

Oblika diskriminatorja je simetrična tej, z razliko, da namesto obratno koračnih, uporabljamo koračne kovolucije z velikostjo koraka 2. Arhitekturi se ločita tudi v tem, da je zadnji sloj v diskriminatorju polnopovezan z velikostjo 1, saj je cilj vračanje enega bita informacije.

V drugem koraku želimo glede na podano sliko $x$ starosti $y_{o}$ poiskati latentni vektor, ki ustvari sliko $\hat{x}$, ki je najboljši približek podani sliki $x$. $\mathrm{V}$ nasprotju z avtoenkoderji nam generativne nasprotniške mreže ne podajo možnosti za preslikavo slike $x \mathrm{z}$ atributi $y \mathrm{v}$ latentni vektor $z$. Imamo torej definirano preslikavo $f:(z, y) \mapsto x$ želimo pa dobiti preslikavo $f^{-1}:(x, y) \mapsto$ $z$.

To lahko rešimo tako, da naučimo enkoder $E$, nevronsko mrežo zadolženo za aproksimiranje $f^{-1}$. Najprej ustvarimo sintetično množico sto tisoč pa$\operatorname{rov}\left(x_{i}, G\left(z_{i}, y_{i}\right)\right)$, kjer so $z_{i}$ normalno porazdeljeni naključni latentni vektorji ter $y_{i}$ enakomerno porazdeljene naključno izbrane oznake starostnih skupin. $G\left(z_{i}, y_{i}\right)$ je na učni množici obrazov in njihovih starosti naučena pogojna nasprotniška generativna mreža (CGAN). Enkoder je naučen tako, da minimiziramo evklidsko razdaljo med aproksimiranimi latentnimi vektorji $E\left(x_{i}\right)$ in $z_{i}$, kjer je $x_{i}=G\left(z_{i}, y_{i}\right)$. 
Dobljeni rezultat je aproksimacija, ki jo želimo še dodatno izboljšati z uporabo optimizacijskih algoritmov. Cilj je minimizirati razdaljo med $x$ in $\hat{x}$. Rezultati se, odvisno od izbrane mere razdalje, precej razlikujejo. Najenostavnejši pristop je uporaba evklidske razdalje na razliki med slikovnimi točkami. Težava nastane, ker metoda gleda razlike med posameznimi slikovnimi točkami, ki velikokrat nimajo vpliva na ohranjanje identitete. Optimizacijska metoda npr. optimizira razlike v ozadju, laseh ipd., čeprav bi želeli, da se identiteti oseb čim bolj približata. Pomanjkljivost je tudi ta, da nam slike zabriše.

Alternativni način je uporaba optimizacije, ki ohranja identitete. Če imamo nevronsko mrežo $F R$, ki predstavlja implementacijo nevronske mreže naučeno v namene razpoznave obrazov [22], lahko definiramo razdaljo kot razliko med reprezentacijami v tej mreži. V največ primerih gledamo evklidsko razdaljo med tenzorji definiranimi znotraj enega od slojev. Velja torej:

$$
z^{*}=\underset{z}{\operatorname{argmin}}=\|F R(x)-F R(\hat{x})\|_{L_{2}} .
$$

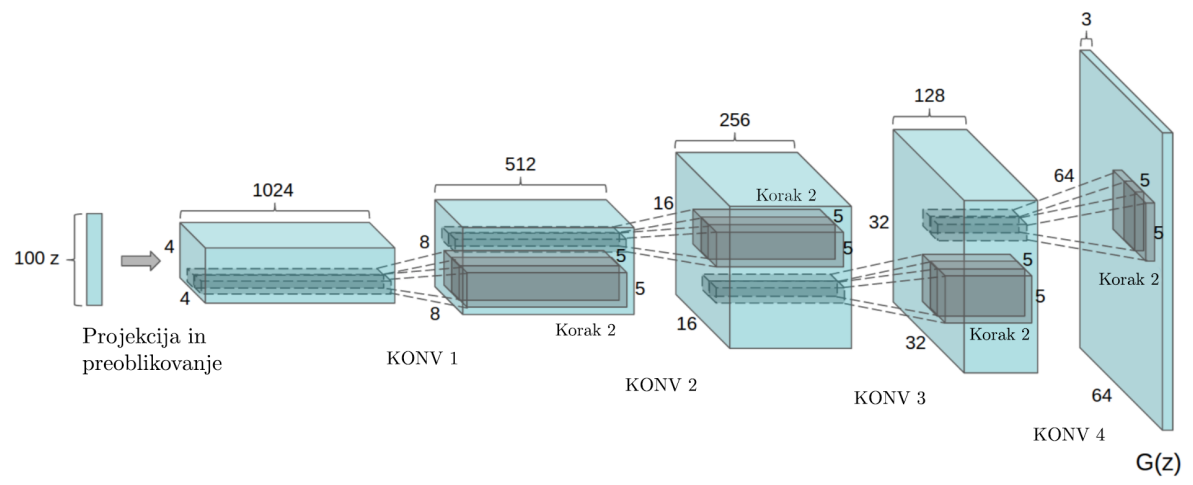

Slika 2.4: Struktura generatorja uporabljenega v [1]. Slika preoblikovana iz $[21]$.

Ker sta tako generator $G(z, y)$ kot nevronska mreža $F R$ odvedljiva glede na vhodne podatke, se optimizacijo lahko rešuje z uporabo L-BFGS-B algoritma [23], ki mu kot začetni približek podamo vrednost $z_{0}$, ki smo jo dobili iz enkoderja $E$. 


\subsubsection{Staranje $\mathrm{z}$ uporabo povratnih nevronskih mrež}

Klasične povratne nevronske mreže (angl. recurrent neural network) podajajo dobre rezultate, kadar se ukvarjamo z zaporednimi podatki, kjer so členi medsebojno odvisni, to pa lahko izkoristimo za simuliranje postopka staranja [19]. Staranje si lahko predstavljamo kot zaporedje stanj, kjer je vsako novo stanje odvisno od prejšnjega. Starosti razdelimo na starostne skupine, cilj pa je najti prehode iz enega stanja v naslednjega. Postopek je sestavljen iz dveh glavnih korakov, kjer je prvi normalizacija obraznih slik, drugi pa staranje s pomočjo mreže. Pomembno je, da nam normalizacija ohrani podatke o starosti ter lepe prehode med starostnimi skupinami. Za dosego tega cilja se poslužimo tehnike, kjer normaliziramo slike sosednih starostnih skupin skupaj. Uporablja se optični tok, saj ohrani teksturne podrobnosti na slikah. Podrobnosti in matematična formulacija so podrobneje predstavljene v [19]. Ko imamo slike normalizirane, se poslužimo povratne nevronske mreže za izvajanje postopka staranja. Osnovna komponenta mreže so dvoslojna GRU (angl. gated recurrent unit) vrata, kjer spodnji GRU zakodira vhodni obraz v skrito visokodimenzionalno reprezentacijo, ki jo zgornji del odkodira v postaran obraz. Kot našo kriterijsko funkcijo določimo razliko med vhodno sliko in referenčno sliko. Uteži postopoma povečujemo tako, da ima največjo težo razlika med najstarejšo starostno skupino in referenco. S tem omogočimo bolj realne prehode med stanji.

\subsubsection{Staranje s pogojnim nasprotniškim avtoenkoder- jem}

Ta metoda temelji na uporabi nasprotniškega avtoenkoderja za doseganje staranja [2]. Predpostavimo, da slike oseb pri različnih starostih ležijo na mnogoterosti $\mathcal{M}$. Premikanje po tem prostoru v določeni smeri nam ohrani identiteto, kljub temu da se starost spreminja. Želimo določiti preslikavo med nižjedimenzionalnim latentnim prostorom in mnogoterostjo, saj je direktna preslikava med sliko in mnogoterostjo pretežka za modeliranje. 
Imamo sliko obraza $x$, ki jo enkoder $E$ preslika v latentno reprezentacijo $z$, ki jo nato združimo z informacijo o starosti osebe $l$. S tem dobimo točko na $\mathcal{M}$. Glavna ideja je, da sta $v$ latentnem prostoru informaciji o identiteti $z$ in starosti $l$ ločeni. To pomeni, da lahko samo spremenimo starost in s tem ohranimo identiteto osebe. S pomočjo generatorja $G$ to preslikamo nazaj v prostor slik, ki so človeku berljive. Za enkoder uporabimo konvolucijsko nevronsko mrežo, kjer se za namene podvzorčenja (angl. downsampling) uporablja koračenje s korakom 2, kot je priporočeno v [21]. Podobno velja za generator. Imamo tudi dva diskriminatorja:

- $D_{z}$ je povezan z enkoderjem in skrbi, da latentni vektorji $z$ sledijo normalni porazdelitvi. S tem želimo prisiliti $E$, da je latentni prostor enakomerno zapolnjen.

- $D_{i m g}$ prisili generator, da so rezultati fotorealistični, še posebej se to vidi pri teksturi starejših obrazov.

Pri podanem latentnem vektorju $z$ ter oznaki $l$ nam generator $G$ ustvari novo sliko $\hat{x}=G(z, l)=G(E(x), l)$. Želimo, da $\hat{x}$ leži na na $\mathcal{M}$ in ima isto identiteto kot $x$. Matematično je naš cilj dobiti rešitev enačbe

$$
\min _{E, G} \mathcal{L}(x, G(E(x), l))
$$

ter hkrati poskrbeti, da je $z$ normalno porazdeljen ter da je kriterij diskriminatorja $D_{\text {img }}$ čim bolj izpolnjen.

Porazdelitev učnih podatkov definiramo kot $p_{\text {data }}(x)$ in porazdelitev $z$ definiramo kot $q(z \mid x)$. Naj bo $p(z)$ priorna porazdelitev, potem z $z^{*} \sim p(z)$ definiramo vzorčenje iz $p(z)$. Skupno učenje $E$ in $D_{z}$ predstavimo s kriterijsko funkcijo:

$$
\min _{E} \max _{D_{z}} \mathbb{E}_{z^{*} \sim p(z)}\left[\log D_{z}\left(z^{*}\right)\right]+\mathbb{E}_{x \sim p_{\text {data }}(x)}\left[\log \left(1-D_{z}(E(x))\right)\right] .
$$

Analogno lahko definiramo kriterijsko funkcijo za učenje diskriminatorja $D_{i m g}$ in generatorja $G$ z oznako $l$ kot:

$\min _{G} \max _{D_{\text {img }}} \mathbb{E}_{x, l \sim p_{\text {data }}(x, l)}\left[\log D_{i m g}(x, l)\right]+\mathbb{E}_{x, l \sim p_{\text {data }}(x, l)}\left[\log \left(1-D_{\text {img }}(G(E(x), l))\right)\right]$. 
Vse skupaj sedaj seštejmo in združimo v celotno kriterijsko funkcijo sistema:

$$
\begin{array}{r}
\min _{E, G} \max D_{z}, D_{\text {img }} \lambda \mathcal{L}(x, G(E(x), l)) \\
+\mathbb{E}_{z^{*} \sim p(z)}\left[\log D_{z}\left(z^{*}\right)\right] \\
+\mathbb{E}_{x \sim p_{\text {data }}(x)}\left[\log \left(1-D_{z}(E(x))\right)\right] \\
+\mathbb{E}_{x, l \sim p_{\text {data }}(x, l)}\left[\log D_{\text {img }}(x, l)\right] \\
+\mathbb{E}_{x, l \sim p_{\text {data }}(x, l)}\left[\log \left(1-D_{\text {img }}(G(E(x), l))\right)\right] .
\end{array}
$$




\section{Poglavje 3}

\section{Implementacija}

Med raziskovanjem načina za doseganje najboljših rezultatov staranja in pomlajevanja smo se poslužili različnih pristopov, ki jih bomo predstavili v tem poglavju. Predstavili bomo teoretično podlago vsakega od njih ter dosežene rezultate. Analizirali bomo pomanjkljivosti in težave pri implementaciji.

Za implementacijo različnih modelov je bila uporabljena programska knjižnica Keras 2.0.0 [24], ki v ozadju uporablja Tensorflow 1.0.0 [25]. Za doseganje enakovrednih rezultatov je verzija pomembna, saj lahko starejše ali novejše različice dajejo bistveno drugačne rezultate.

\subsection{Pogojna generativna nasprotniška mreža}

\subsubsection{Teoretično ozadje}

Kot je že bilo omenjeno v [9] je ena najbolj osnovnih razširitev GAN modelov, razširitev na pogojno mrežo, ki je bila natančneje formalizirana v [26]. Ideja je enostavna, mrežo lahko razširimo v pogojni model tako, da pogojimo tako diskriminator kot generator z oznako informacije $y$. To informacijo podamo kot dodaten vhodni sloj obema deloma mreže. V praksi za y največkrat uporabljamo zapis v obliki oznake pripadnosti (angl. one-hot vector), ki nam pove, kateremu razredu pripada določena informacija. 
Formalno se enačba 2.2, ki opisuje nasprotniško delovanje dveh delov mreže osnovne oblike, sedaj razširi v

$$
\left.\min _{G} \max _{D} V(D, G)=\mathbb{E}_{x \sim p_{\text {data }}(x)}[\log D(x \mid y)]+\mathbb{E}_{z \sim p_{z}(z)}[\log 1-D(G(z \mid y)))\right]
$$

V primeru, da je arhitektura naše mreže sestavljena iz polnopovezanih slojev, lahko informacijo o razredu (oznaki) priključimo enemu od polnopovezanih slojev tako, da jo enostavno dodamo na konec enega od slojev. V praksi to ponavadi naredimo v enem od prvih slojev mreže.

Kadar pa je naša mreža sestavljena samo iz konvolucijskih slojev, potem se moramo zateči $\mathrm{k}$ drugim načinom pogojitve modela. Konvolucijskemu sloju zaradi razlik v dimenzionalnosti namreč ni mogoče pripeti dodatne informacije o razredu. V tem primeru uporabimo trik, kjer glede na razred, vsak vhod pomnožimo z določeno skalarno vrednostjo. To nam omogoči, da vhodne podatke glede na razred razpršimo po prostoru in tako dosežemo, da mreža razlikuje med različnimi razredi vhodnih podatkov.

\subsubsection{Implementacija}

V našem primeru smo želeli preizkusiti pogojno generativno nasprotniško mrežo kot osnovni generativni model, nad katerim bi potem preizkušali nove metode. Začeli smo s polnopovezano arhitekturo, ki je najenostavnejša za implementacijo. Na sliki 3.1 vidimo arhitekturo našega modela. V genera-

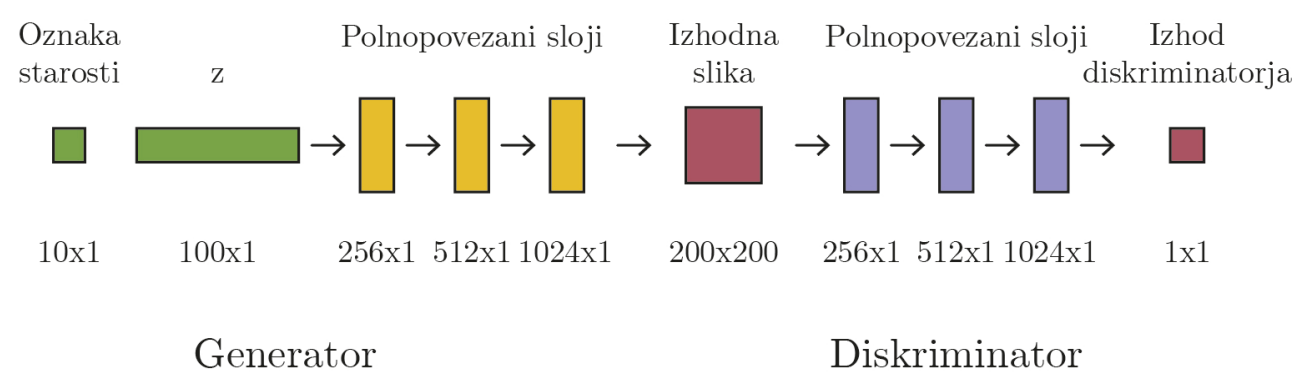

Slika 3.1: Arhitektura polnopovezanega CGAN modela. 
torju je med polnopovezanimi sloji dodana še normalizacija svežnjev. Velja, da v vseh polnopovezanih slojih generatorja uporabimo puščajočo usmerjeno linearno enoto kot aktivacijo, razen v zadnjem, kjer se uporablja tanh. Pri diskriminatorju je med vsemi polnopovezanimi sloji dodan osipni (angl. dropout) sloj. Podobno kot prej, za aktivacijo povsod uporabljamo puščajočo usmerjeno linearno enoto, razen v zadnjem sloju, kjer se uporablja sigmoid.

Arhitektura je neodvisna od velikosti vhoda, vendar smo se odločili, da bomo naš model preizkušali na slikah velikost $200 \times 200$ slikovnih točk. Kot kriterijsko funkcijo tako generatorja kot diskriminatorja uporabljamo binarno navzkrižno entropijo (angl. binary crossentropy). Prav tako je to uporabljeno za skupni model.

Učenje je potekalo tako, da smo v vsaki iteraciji najprej učili diskriminator. Na vhod smo mu podali slike ustvarjene iz strani generatorja, skupaj z oznako starosti. Za te učne podatke smo želeli, da diskriminator na izhodu vrne vrednost 1 . Kazali pa smo mu tudi naključno ustvarjene slike šuma skupaj z oznakami starosti. V tem primeru smo podali vrednost 0 kot zaželjeni izhod. Sledi učenje skupnega modela, kjer na vhod podamo vektor $z$ ter oznako o starosti, na izhodu pa kažemo vektor enic. Kot optimizator smo uporabljali algoritem ADAM [27] z nastavljeno hitrostjo učenja 0,005. Velikost svežnja smo nastavili na 32.

\subsection{Pogojni Wasserstein GAN}

Eden od prvih preizkušenih modelov je bila pogojna različica Wassersteinovega GAN modela [28]. Eden od glavnih izzivov pri učenju GAN modelov je nastabilnost učenja, kar pa naj bi Wassersteinova različica odpravila.

\subsubsection{Teoretično ozadje}

Pri učenju generativnih modelov predpostavimo, da podatki prihajajo iz neke porazdelitve, katere aproksimacijo $P_{\theta}$ se želimo naučiti. Da to dosežemo, lahko definiramo slučajno spremenljivko $Z$, ki ima fiksno porazdelitev $p(z)$. 
To lahko s pomočjo nevronske mreže (parametrične funkcije) preslikamo v novo slučajno spremenljivko, ki generira vzorce s porazdelitvijo $P_{\theta}$.

$$
g_{\theta}: \mathcal{Z} \leftarrow \mathcal{X}
$$

S spreminjanjem parametrov $\theta$, lahko dosežemo, da se $P_{\theta}$ približa porazdelitvi podatkov $P_{r}$. Želimo izbrati pravilno metriko za definiranje razdalje med dvema porazdelitvama. Obstaja nekaj standardnih možnosti, ki jih lahko uporabimo:

- Razdalja skupne variance (angl. total variance)

$$
\delta\left(\mathbb{P}_{r}, \mathbb{P}_{g}\right)=\sup _{A \in \Sigma}\left|\mathbb{P}_{r}(A)-\mathbb{P}_{g}(A)\right|
$$

\section{- Kullback-Leibler (KL) divergenca}

$$
K L\left(\mathbb{P}_{r} \| \mathbb{P}_{g}\right)=\int \log \left(\frac{P_{r}(x)}{P_{g}(x)}\right) P_{r}(x) d \mu(x)
$$

Največja težava tukaj je asimetričnost, torej $K L\left(\mathbb{P}_{r} \| \mathbb{P}_{g}\right) \neq K L\left(\mathbb{P}_{g} \| \mathbb{P}_{r}\right)$ ter dejstvo, da je mera neskončna, kadar velja $P_{g}(x)=0$ in $P_{r}(x)>0$. To nam lahko povzroča težave v začetnih fazah učenja nevronske mreže.

\section{- Jensen-Shannon (JS) divergenca}

$$
J S\left(\mathbb{P}_{r}, \mathbb{P}_{g}\right)=K L\left(\mathbb{P}_{r} \| \mathbb{P}_{m}\right)+K L\left(\mathbb{P}_{g} \| \mathbb{P}_{m}\right),
$$

kjer je $\mathbb{P}_{m}$ enak $\left(\mathbb{P}_{r}+\mathbb{P}_{g}\right) / 2$. To nam odpravi največje pomanjkljivosti KL divergence, saj je simetrična ter vedno manjša od neskončnosti, saj lahko izberemo $\mu=\mathbb{P}_{m}$.

\section{- Wasserstein-1 razdalja}

$$
W\left(\mathbb{P}_{r}, \mathbb{P}_{g}\right)=\inf _{\gamma \in \Pi\left(\mathbb{P}_{r}, \mathbb{P}_{g}\right)} \mathbb{E}_{(x, y) \sim \gamma}[\|x-y\|],
$$

kjer nam $\Pi\left(\mathbb{P}_{r}, \mathbb{P}_{g}\right)$ predstavlja množico vseh skupnih porazdelitev $\gamma(x, y)$, katerih marginala sta $\mathbb{P}_{r}$ in $\mathbb{P}_{g}$. Lahko si predstavljamo kot, koliko mase je potrebno prestaviti iz ene porazdelitve, da dobimo drugo. 
Izkaže se, da je za nas ta mera najbolj zanimiva, saj določena enostavna zaporedja porazdelitev konvergirajo glede na to razdaljo in ne glede na druge. V tej obliki te razdalje ni mogoče izračunati, vendar po Kantarevich-Rubensteinovi dualnosti je zgornja definicija razdalje ekvivalentna:

$$
W\left(P_{r}, P_{\theta}\right)=\sup _{\|f\|_{L} \leq 1} \mathbb{E}_{x \sim P_{r}}[f(x)]-\mathbb{E}_{x \sim P_{\theta}}[f(x)] .
$$

Psevdokoda WGAN učenja se zapiše kot:

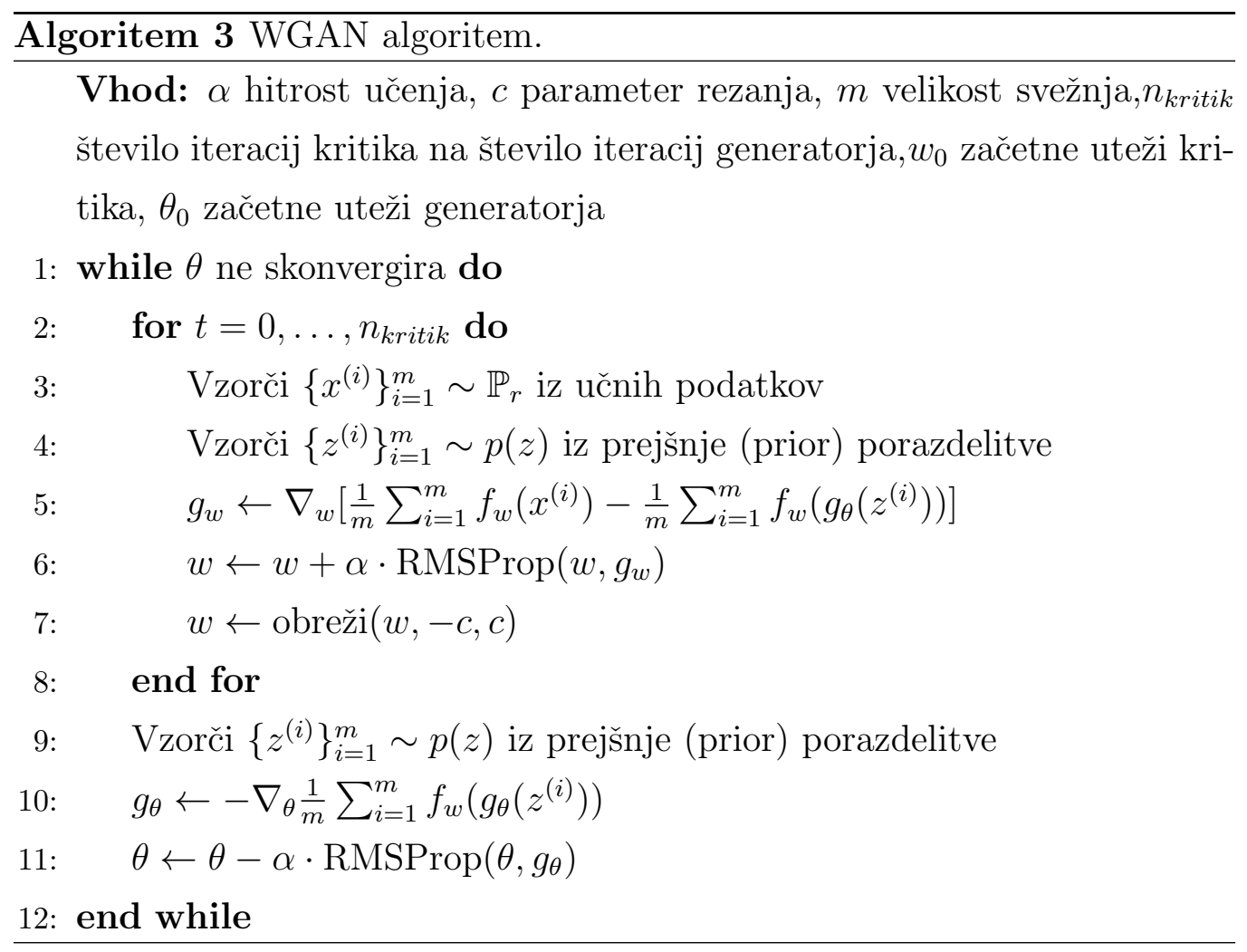

Velja, da je za doseganje Lipschnitzovega pogoja dovolj, da vrednosti funkcije obrežemo (angl. clip) med dve možni vrednosti, ki jih nastavimo s parametrom $c$, kar moramo storiti po vsaki posodobitvi uteži $w$ [28].

\subsubsection{Implementacija}

Za doseganje staranja s pomočjo WGAN modela smo želeli najprej preizkusiti WGAN kot klasični pogojni generativni model. Želeli smo, da bi mreža glede 
na vhodni šumni vektor ter oznako starosti ustvarila sliko osebe, katere izgled je primeren glede na ciljno starostno skupino. Preizkusili smo dve standardni arhitekturi za obliko generatorja in diskriminatorja. Prva arhitektura je bila konvolucijska in je bila osnovana na predlogah iz [21], vendar smo naredili nekaj sprememb. Na sliki 3.2 vidimo shemo generatorja. Pri tem z $v$ in $s$ označimo vhodne dimenzije slike ter z $g$ število filtrov, ki smo jih nastavili na 64 .

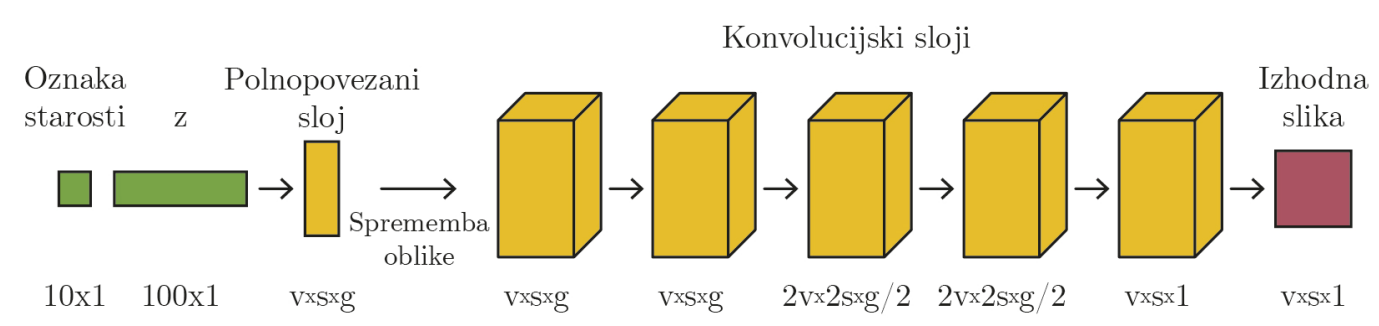

Slika 3.2: Arhitektura generatorja konvolucijskega CWGAN modela.

Shema diskriminatorja je podobna. Narejena je tako, da takoj po vhodu sledijo konvolucijski sloji iste dimenzije kot pri generatorju, vendar v obratnem vrstem redu. Za tem pa zravnamo to kar smo dobili s konvolucijami in dodamo polnopovezani sloj velikosti 1. Pri generatorju med vsemi sloji uporabljamo tako osipni (angl. dropout) sloj kot normalizacijo svežnjev. Za aktivacijo pri vseh slojih se uporablja puščajoča usmerjena linearna enota, razen v zadnjem konvolucijskem sloju, kjer je aktivacijska funkcija tanh.

Za diskriminator velja, da med vsemi sloji uporabljamo osipni (angl. dropout) sloj ter aktivacijo s puščajočo usmerjeno linearno enoto za vse sloje, razen za zadnji polnopovezani sloj, kjer se uporablja aktivacija z usmerjeno linearno enoto.

V sklopu učenja smo uporabljali RMSProp [29] optimizator z nastavljeno hitrostjo učenja na 0,0005. Parameter rezanja je bil standardno nastavljen na $(-1,1)$ ter $n_{k r i t i k}=5$. Velikost svežnja pa smo nastavili na 32 . Začetne uteži so bile inicializirane z vzorčenjem iz normalne porazdelitve. Želeli smo mrežo najprej preizkusiti na enostaven način, zato smo se odločili za velikost slike $64 \times 64$ slikovnih točk ter za enokanalne slike. Vsakega od različnih 
modelov smo učili za dolžino 20000 svežnjev.

Učenje je potekalo na isti način kot pri implementaciji CGAN modela, kjer smo najprej učili diskriminator, nato pa še skupni model.

\subsection{BICOGAN}

\subsubsection{Teoretično ozadje}

Klasični GAN modeli nam omogočijo dobiti preslikavo iz prostora šuma z $\mathrm{v}$ prostor generiranih podatkov $x$, vendar v procesu učenja žal ne dobimo obratne preslikave $x \mapsto z$, kar je $\mathrm{v}$ določenih primerih zaželjeno, saj nam omogoča dobiti kompaktno reprezentacijo naše informacije $x$.

Rešitev tega problema je model, ki pogojno generativno nasprotniško mrežo poveže z enkoderjem, ki je zadolžen za določanje inverzne preslikave [30]. Velja, da v idealnem primeru morata biti $G$ in $E$ inverzna, da lahko prelisičita diskriminator $D$ [31].

$\mathrm{V}$ tem primeru se GAN enačba, zapisana v enačbi (2.2) spremeni v:

$$
\min _{G} \max _{D} V(D, G)=\mathbb{E}_{x \sim p_{\text {data }}(x)}[\log D(x, c)]+\mathbb{E}_{z \sim p_{\tilde{z}}(\tilde{z})}[\log (1-D(G(\tilde{z}, c))]
$$

Ta model je zanimiv, saj bi omogočil, da bi lahko postopek iz [1] poenostavili na način, kjer bi bila potrebna uporaba samo ene nevronske mreže. Pri omenjenem pristopu so za določanje preslikave iz prostora slik v prostor latentnih vektorjev uporabili dodatno nevronsko mrežo, kar pa zahteva izgradnjo dodatnega modela ter učenja, ki je ločen od generiranja slik.

Želja je bila, da bi z uporabo dvosmernega učenja, hkrati učili tako generator in diskriminator kot tudi enkoder. Idejno arhitekturo naše mreže v shematski obliki vidimo na sliki 3.3.

Če se nanašamo na oznake definirane v poglavju 3.1 o GAN mrežah, potem formalno rečemo, da se generator nauči preslikavo $G\left(\tilde{z}, \theta_{G}\right)$ iz porazdelitve $p_{\tilde{z}}$, kjer je $\tilde{z}=[z c]$, v porazdelitev $p_{G}$, kjer je glavni cilj, da se $p_{G}$ in $p_{\text {data }}$ čim manj razlikujeta. Naloga enkoderja $E\left(x ; \theta_{E}\right)$ je, da slika iz $p_{\text {data }} \mathrm{V}$ 


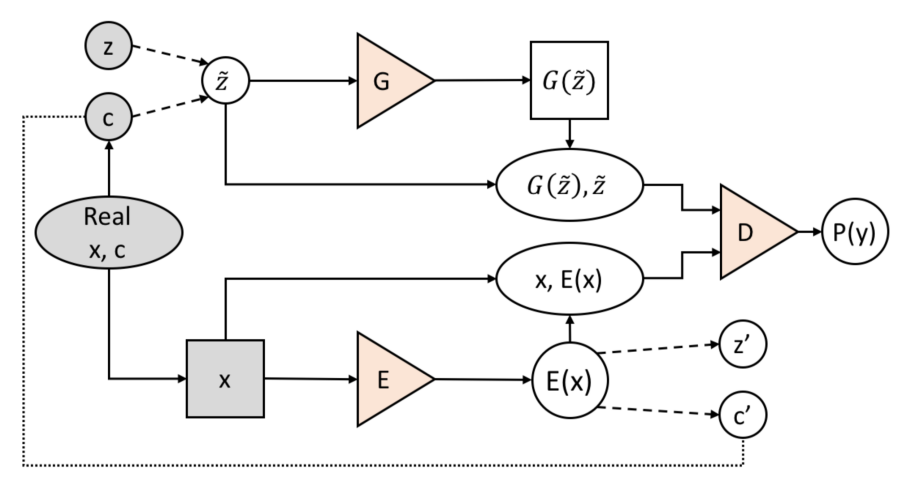

Slika 3.3: Idejna zasnova BICOGAN arhitekture [30].

$p_{E}$, kjer želimo, da je $p_{E}$ čim bližje $p_{\tilde{z}}$. Diskriminator se odloča o avtentičnosti vzorca glede na $D\left(\tilde{z}, G(\tilde{z}) ; \theta_{D}\right)$ in $D\left(E(x), x ; \theta_{D}\right)$.

$\mathrm{V}$ splošnem primeru BICOGAN modela se mora enkoder naučiti inverzno preslikavo iz $x \mathrm{v} z$ in $c$. Ker pa je to $\mathrm{v}$ našem primeru nepotrebno, smo naš model spremenili tako, da je informacija o oznaki $c$ enkoderju vedno podana.

\subsubsection{Implementacija}

Poizkusili smo z implementacijo BICOGAN modela v orodju Keras. Kot najenostavnejšo obliko smo za vse tri notranje mreže (diskriminator, generator, enkoder) uporabili polnopovezano arhitekturo. Generator je sestavljen iz treh polnopovezanih slojev, katerih prva dva sta velikosti 512, tretji pa je velikosti števila slikovnih točk vhodne slike. Med polnopovezanimi sloji uporabljamo aktivacijo s puščajočo usmerjeno linearno enoto. Tudi diskriminator ima tri polnopovezane sloje, vendar velja, da sta prva dva velikosti 1024, tretji pa velikosti 1 . V zadnjem sloju se uporablja sigmoid aktivacija, medtem ko za ostale uporabljamo puščajočo usmerjeno linearno enoto. Enkoder ima isto strukturo kot generator, le da je velikost zadnjega polnopovezanega sloja enaka velikosti latentnega vektorja, ki smo jo nastavili na na 100.

Za učenje uporabimo optimizator ADAM, ki mu hitrost učenja nastavimo na 0,0002 ter učimo v svežnjih velikosti 16 . 


\subsection{Variacijski avtoenkoder}

\subsubsection{Teoretično ozadje}

Teoretično ozadje tega modela smo predhodno že predstavili v poglavju 2.3 znotraj pregleda področja. Velja ponoviti, da ideja variacijskega avtoenkoderja temelji na tem, da generiramo latentne vektorje, ki približno sledijo naravni porazdelitvi. V praksi potrebujemo kompromis med kodiranjem informacije in uveljavljanjem porazdelitve. Naša kriterijska funkcija je sestavljena iz dveh uteženih delov, KL divergence in rekonstrukcijske napake, katerih vsota nam poda končni kriterij kvalitete. Nove slike dobimo z vzorčenjem latentnih vektorjev iz normalne porazdelitve, ki jih podamo delu mreže, ki služi kot generator. Razširitve ter verzije tega modela opisane v nadaljevanju so osnovane na tem principu.

\subsubsection{Implementacija}

Zaradi nezadovoljivih rezultatov dobljenih s pomočjo različnih inačic generativnih nasprotniških mrež smo se odločili za preizkus metod, ki uporabljajo variacijske avtoenkoderje. Najprej smo želeli preizkusiti VAE kot generativni model, ki je sposoben ustvariti realne slike obrazov različnih starosti.

\section{Enostavna polnopovezana arhitektura}

Zgradili smo najenostavnejšo arhitekturo, sestavljeno iz polnopovezanih slojev, ki je predstavljena na sliki 3.4.

Z zeleno barvo so označeni vhodni sloji, z rumeno barvo je označen del mreže, ki pripada enkoderju $E$, z vijolično barvo pa tisti del, ki pripada dekoderju $D$. Kot izhodni podatek, označen z rdečo, dobimo sliko, ki jo je enkoder ustvaril iz latentnega vektorja, ki je bil vzorčen.

Glavna ideja variacijskega avtoenkoderja je vzorčenje latentnega vektorja iz dveh polnopovezanih slojev, katerih nevroni predstavljajo srednjo vrednost in varianco. Kadar želimo dobiti latentni vektor, vzorčimo iz sloja stan- 


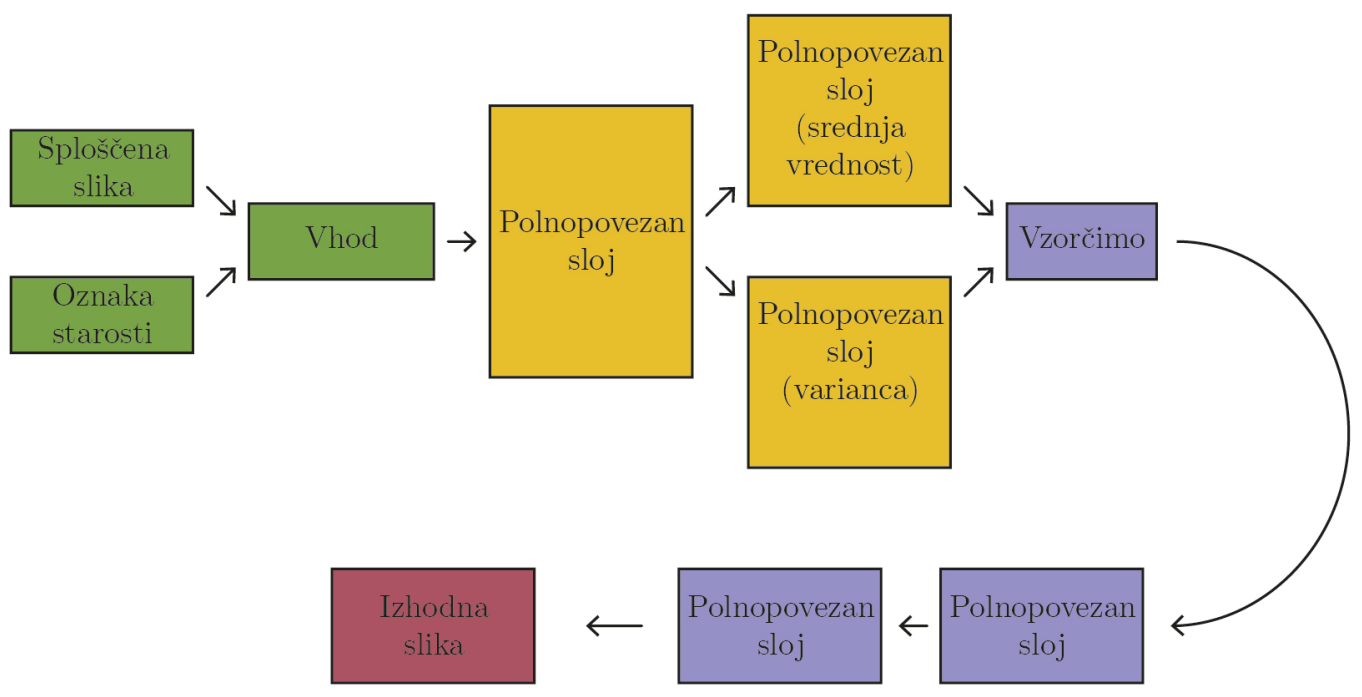

Slika 3.4: Najenostavnejša arhitektura variacijskega avtoenkoderja.

dardnih deviacij in mu prištejemo srednjo vrednost. Vrednost vzorčenja $v$ matematično zapišemo kot:

$$
v=\mu+e^{\sigma} \epsilon,
$$

kjer $\epsilon$ predstavlja vzorčeno vrednost iz naravne porazdelitve s standardno deviacijo $\epsilon_{\text {std }}$. To lahko nastavljamo kot parameter našega modela.

Velikosti vseh notranjih slojev so prepuščene izbiri in so določene glede na vhodne podatke in empirično preizkušanje.

V našem primeru smo nastavili dimenzijo prvega polnopovezanega sloja v $E$ na 512 nevronov, medtem ko smo velikost slojev srednjih vrednosti in variance nastavili na 100. Sloj vzorčenja mora tudi imeti dimenzijo 100. Prvi polnopovezan sloj $D$ je dimenzije 512 , medtem ko mora drugi polnopovezan sloj imeti dimenzijo enako velikosti izhodne slike.

Pri $E$ uporabljamo aktivacijo z usmerjeno linearno enoto za polnopovezan sloj ter linearno aktivacijo za sloj s srednjo vrednostjo in standardno variacijo. Podobno velja, da ima prvi sloj dekoderja aktivacijo z usmerjeno linearno enoto, zadnji pa sigmoid. 
Pri variacijskem avtoenkoderju imamo še en parameter, ki bistveno vpliva na potek učenja in sicer razmerje med rekonstrukcijsko napako in KL divergenco, katerih seštevek predstavlja kriterijsko funkcijo modela. Absolutna vrednost teh dveh količin je precej različna, zato ju moramo normalizirati. Opazili smo, da razmerje med tema dvema količinama močno spremeni naše rezultate. V primeru, ko prevlada rekonstrukcijska napaka, dobimo precej dobre rekonstrukcije originalnega vhoda, vendar staranje ne deluje. Kadar pa prevlada KL divergenca, dobimo zelo povprečne obraze vseh starostnih skupin, kar nam za naš namen ne koristi. Ko pomislimo o definiciji KL divergence, ima to smisel, saj velja, da je KL divergenca mera razdalje med dvema verjetnostnima porazdelitvama. Tukaj je ena od porazdelitev tista, ki se jo učimo v želji, da bi lahko generirali slike, ki so podobne vhodnim. Druga pa predstavlja normalno porazdelitev na prostoru vseh obrazov. Kadar KL divergenca prevlada, je torej zelo blizu povprečnemu obrazu in identiteta osebe se $\mathrm{v}$ procesu izgubi.

Kot pravilo palca smo najprej normalizirali rekonstrukcijsko napako z velikostjo vhodnih podatkov. Na primer, če smo imeli velikost vhodne slike $128 \times 128$ slikovnih točk in enokanalno sliko, smo vrednost delili s številom 16384. KL divergenco pa smo delili z velikostjo latentnega prostora. Dodali smo še eno utež, ki je delovala neodvisno od dimenzije slike in smo jo spreminjali, da bi dobili najboljše razmerje med obema vrednostima. Empirično smo ugotovili, da smo dobili najboljše rezultate, ko smo dodatno pomnožili KL divergenco s faktorjem okoli 0,1 .

Spreminjanje $\epsilon_{\text {std }}$ nam, glede na izkušnje iz preizkušanja, naredi podobno kot zgoraj opisano razmerje. Z zmanjšanjem parametra dosežemo, da generiranje slike ohranijo večjo podobnost vhodni slike in manjšo podobnost povprečju celega razreda. Zaradi narave našega problema, ohraniti želimo identiteto ob prilaganju povprečju razreda (starosti), je težko določiti optimalno mejo.

Dobljeni rezultati so predstavljeni v poglavju 4 o rezultatih, vendar velja omeniti, da smo dosegli precej boljšo vizualno kvaliteto kot pri generativ- 
nih nasprotniških mrežah. Ker je predstavljena arhitektura najbolj osnovna možna, smo se odločili, da bomo poizkusili z implementacijo konvolucijskega variacijskega avtoenkoderja, ki je bolj primeren za delovanje na slikah.

\section{Konvolucijska arhitektura}

Odločili smo se za konvolucijsko arhitekturo s štirimi zaporednimi konvolucijskimi sloji v enkoderju ter analogno arhitekturo v dekoderju. Na sliki 3.5 vidimo arhitekturo enkoderja, medtem ko na sliki 3.6 vidimo arhitekturo dekoderja.

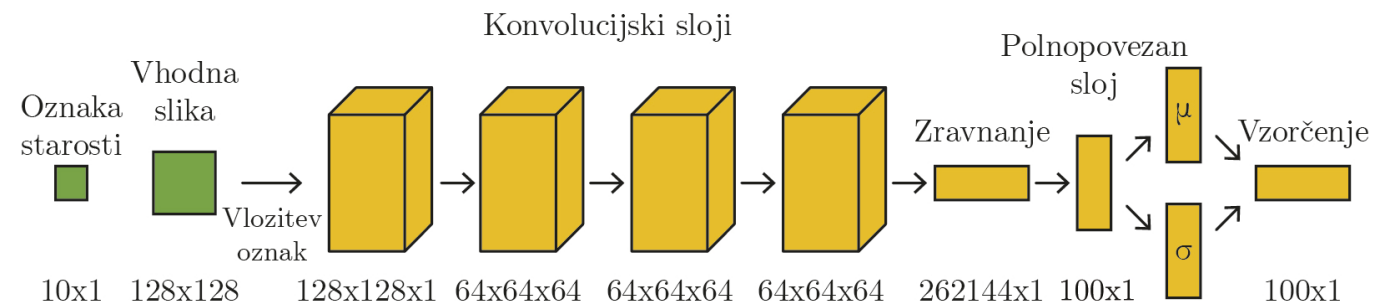

Slika 3.5: Arhitektura enkoderja pri konvolucijskem VAE modelu.

Velja omeniti, da so dimenzije konvolucijskih slojev odvisne od velikosti vhodnih podatkov. Shema modela je narejena pri predpostavki, da je velikost vhodne slike $128 \times 128$ slikovnih točk ter da generiramo latentni vektor velikosti 100. Predvsem velikost latentnega vektorja lahko močno vpliva na kvaliteto generiranih slik.

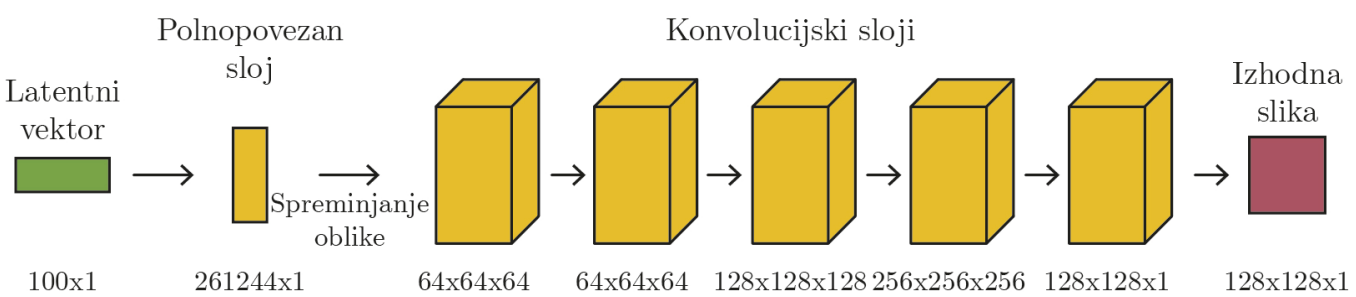

Slika 3.6: Arhitektura dekoderja pri konvolucijskem VAE modelu.

Poleg parametrov, ki smo jih definirali pri polnopovezani arhitekturi, imamo pri konvolucijskem modelu dodatne parametre, ki vplivajo na končni 
rezultat. Prvi je število filtrov, ki določa koliko filtrov se naša mreža uči v vsakem od slojev. Kot vidimo na slikah 3.5 in 3.6 je standardno število filtrov v konvolucijskih slojih nastavljeno na 64 . V propagaciji skozi dekoder, se število filtrov spreminja skupaj z dimenzijo. Poleg tega pa je pomembno določiti tudi velikost jedra konvolucije. V enkoderju imamo velikost jedra 2 , v dekoderju pa 3 . V vseh slojih uporabljamo aktivacijo z usmerjeno linearno enoto, razen v zadnjem sloju dekoderja, kjer se kot aktivacija uporablja sigmoid. Kot optimizator smo uporabili RMSProp.

\section{Konvolucijska arhitektura s kritikom identitete}

V sklopu preizkušanja modelov smo naleteli na težavo, da so bile generirane slike preveč povprečne. Poizkušali smo spreminjati različne parametre našega modela, vendar nam večjih izboljšav ni uspelo doseči. To težavo smo želeli odpraviti z implementacijo variacijskega avtoenkoderja, kateremu bi dodali kritika, ki bi bil zadolžen za usmerjanje mreže v smeri ohranjanja identitete. Naš idejni model je predstavljen na sliki 3.7, kjer lahko vidimo, da je kritik

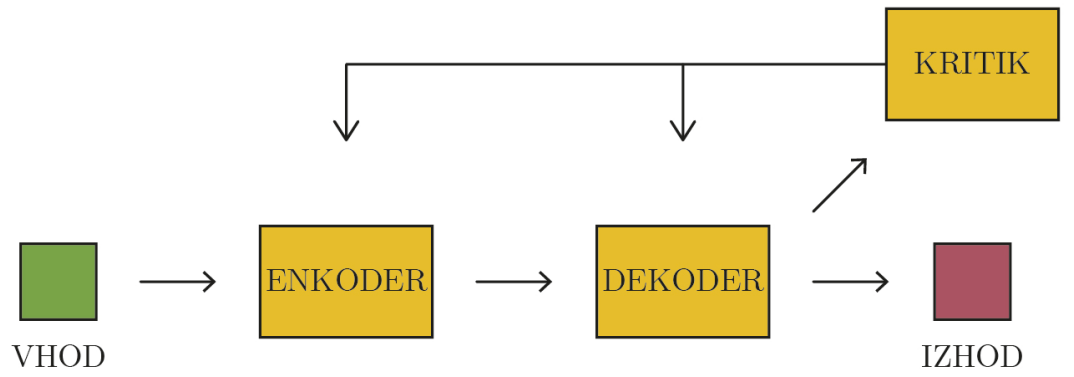

Slika 3.7: Idejna zasnova variacijskega avtoenkoderja s kritikom identitete.

povezan z izhodom in usmerja celotno mrežo (tako enkoder kot dekoder) v to, da bi generirala boljše slike. Kritik deluje tako, da sprejme vhodno ter generirano sliko ter nam vrne mero podobnosti med identitetami oseb na teh slikah. Želimo torej dodaten kriterij v kriterijski funkciji, ki bi poskrbel za podobnost identitet. Cilj je minimizirati naslednjo vsoto $\mathcal{L}=\lambda_{1} \mathcal{L}_{K L}+$ $\lambda_{2} \mathcal{L}_{\text {rekon }}+\lambda_{3} \mathcal{L}_{\text {id }}$, kjer lahko vsakega od členov celotne kriterijske funkcije 
pomnožimo s skalarjem in s tem reguliramo njegovo pomembnost.

Zelo je pomembna izbira kritika identitete. Najprej smo poizkušali uporabiti prednaučeni model Squeezenet mreže, ki je bila učena na obrazih [32]. Arhitektura Squeezenet mreže je predstavljena v [33].

Posebnost te mreže so t.i. prožitveni (angl. fire) moduli, ki so sestavljeni iz treh konvolucij, ki vhod stisnejo in nato ponovno razširijo. Ta mreža je dosegala zelo dobre rezultate pri klasifikaciji, največja prednost pa je fizična velikost modela. Zaradi omejitev strojne opreme, natančneje spomina na grafični kartici, je to lahko zelo priročno, saj se ob večjih modelih hitro lahko zgodi, da presežemo omejitve strojne opreme. V takem primeru moramo praviloma zmanjševati velikost svežnjev pri učenju, kar nam podaljša učni čas.

Mreža je bila predhodno učena na množici obraznih slik z namenom klasifikacije oseb. Uporabljala se je baza iz dela [34]. Za razliko od naše podatkovne baze, slike v tej bazi niso bile poravnane ter obrezane, da bi upoštevale samo obrazni del, brez ostalih faktorjev, kot so obleka, lasje ipd. Pred preizkušanjem nismo vedeli, ali bo to predstavljalo težavo, saj nam ni bilo znano, koliko se prednaučena mreža zanaša na značilke pridobljene iz konteksta slike.

Mreža je narejena za klasifikacijo, torej nam ob podani vhodni sliki vrne vektor verjetnosti, ki oceni, katera oseba je na sliki. Vsak element tega vektorja predstavlja eno od oseb iz učne množice. Ker je podatkovna baza, ki jo uporabljamo za staranje, različna in posledično identitete oseb drugačne kot v Squeezenet mreži, moramo implementacijo malenkost spremeniti. Namesto, da vračamo končni vektor verjetnosti, mrežo odrežemo pred zadnjim slojem in vračamo vektor značilk, dolžine 2048, ki opisuje identiteto osebe v reprezentaciji nevronske mreže.

Kadar želimo primerjati podobnost dveh slik obrazov, lahko uporabimo kosinusno razdaljo, ki je definirana kot:

$$
\text { podobnost }=\frac{\mathbf{A} \cdot \mathbf{B}}{\|\mathbf{A}\| \cdot\|\mathbf{B}\|}=\frac{\sum_{i=1}^{n} A_{i} B_{i}}{\sqrt{\sum_{i=1}^{n} A_{i}^{2}} \sqrt{\sum_{i=1}^{n} B_{i}^{2}}},
$$

kjer sta $\mathbf{A}$ in $\mathbf{B}$ vektorja, ki ju želimo primerjati in $A_{i}, B_{i}$ njune kompo- 


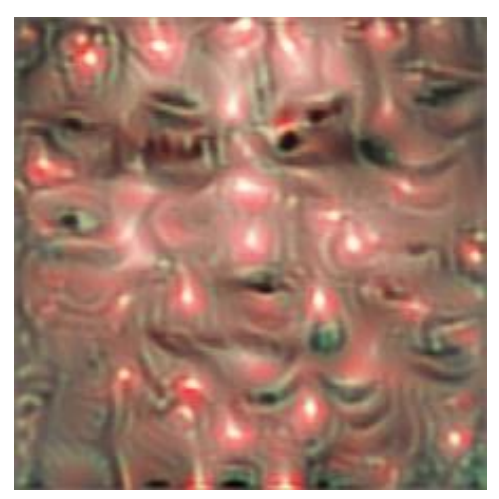

Slika 3.8: Artefakti na slikah ob uporabi kritika.

nente. Kot je očitno iz enačbe, se formula precej poenostavi, če sta vektorja normalizirana. $\mathrm{V}$ takem primeru moramo za mero podobnosti izračunati le skalarni produkt med tema dvema vektorjema. Mera se giblje med -1 in 1 , kjer 1 označuje največjo podobnost in -1 največjo različnost.

Za implementacijo našega modela smo morali najprej za vse slike v naši učni množici izračunati vektor značilk, da smo generirano sliko lahko primerjali z obrazom, ki je bil podan na vhod. Končni model je torej na vhod prejel sliko osebe, njeno starost ter vektor predhodno izračunanih značilk identitete, na izhod pa je vrnil ustvarjeno sliko ter vektor pripadajočih značilk. Ker je ta vektor potreben za izračunanje kriterijske funkcije, govorimo o enovitem učnem postopku (angl. end-to-end training). Velja omeniti, da sta bila enkoder in dekoder definirana s konvolucijsko arhitekturo, kot je opisana $\mathrm{V}$ prejšnjem podpoglavju 3.4.2. Tudi uporabljeni parameteri učenja so bili isti kot tam.

Želeli smo torej, da bi dodaten kriterij usmeril mrežo k ohranjanju identitete originalne slike. S pravilnim uteževanjem smo stremeli h ravnovesju, ki bi omogočalo generiranje obrazov drugačne starosti, vendar z ohranjeno identiteto. Kljub spreminjanju uteži ter parametrov smo dobili rezultate, ki niso bili primerni za uporabo. Eden od primerov je viden na sliki 3.8. Na generiranih slikah so se namreč pojavljali artefakti, ki so popolnoma pokvarili videz slike. Razloga za pojav artefaktov nismo poznali, zato smo poizkusili 
implementirati kritika s pomočjo druge klasifikacijske mreže. Poizkusili smo z dvema mrežama, VGG-FACE [34] in Inception-V3 [35]. VGG arhitektura [36] na vhod dobi trikanalno RGB sliko velikosti $224 \times 224$ slikovnih točk. Sliko pošljemo skozi zaporedje več konvolucijsih slojev, kjer so uporabljeni filtri zelo majhne velikosti, praviloma $3 \times 3$. To je najmanjša velikost jedra, ki še omogoča zajemanje gibanja. Nekaterim konvolucijskim slojem sledijo agregacijski sloji z maksimizacijo (angl. max-pooling), ki imajo okno velikosti $2 \times 2$ z nastavljenim preskokom 2 . Zaporedju teh konvolucijskih slojev sledijo trije polnopovezavni sloji. Prva dva sta velikosti 4096 nevronov, tretji pa velikosti 1000 nevronov, saj je zadolžen za klasifikacijo problema s toliko razredi. Zadnji sloj je ohlapni maksimum (angl. softmax). Vsi notranji sloji uporabljajo aktivacijo z usmerjeno linearno enoto.

Imamo več različic VGG arhitekture, katerih glavna razlika pa je le skupno število konvolucijskih slojev v mreži. V našem primeru smo uporabili VGG-16 arhitekturo. Največja prednost Inception arhitekture v primerjavi z VGG arhitekturo je drastično manjše število parametrov, vendar za ceno veliko večje kompleksnosti. To nam oteži spreminjanje mreže, da bi bolje ustrezala novim namenom.

Vse podrobnosti o arhitekturi so natančno opisane v [35]. V našem primeru smo dobili prednaučeni mreži, ki sta bili učeni na učni mmnožici iz [34]. Implementacija in prednaučeni modeli, tako VGG-Face kot Squeezenet arhitekture omenjene zgoraj, so pridobljeni iz [32].

Žal se rezultati, ki smo jih dobili v skupnem modelu niso drastično izboljšali. Kljub velikim spremembam v arhitekturi kritika se artefaktov nismo mogli znebiti. Opazili smo samo spremembo v sami obliki artefaktov, predvsem pri uporabi Inception-V3 arhitekture, kar lahko vidimo na sliki 3.9. V poglavju Rezultati 4.2.4 je predstavljeno nekaj izmed dobljenih primerkov rezultatov, vendar podrobni vizualni rezultati za vsako arhitekturo niso predstavljeni, saj so si bili med seboj zelo podobni in za naš cilj niso bili dovolj kvalitetni. Zato predstavimo samo vzorec rezultatov dobljenih med raziskovanjem. 


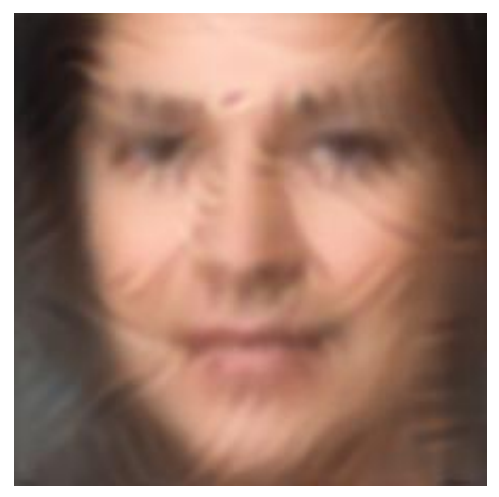

Slika 3.9: Artefakti na slikah ob uporabi Inception-V3 mreže.

\section{Učenje kritika na isti bazi}

Problem je bil očitno neodvisen od arhitekture kritika, zato je bilo težavo potrebno reševati na drugačen način. Kritika smo želeli učiti s pomočjo iste baze, kot bo potekalo učenje mreže staranja. Težava je nastala pri iskanju primerne podatkovne baze. Ta je namreč potrebovala tako anotacije za starost kot anotacije za identiteto. Potrebno je bilo, da imamo v bazi osebe, ki so predstavljene z večimi slikami. To je potrebno za učenje identitetnega klasifikatorja. Ideja je bila, da naučimo klasifikator ter podobno kot v prejšnjem primeru vzamemo značilke iz zadnjega polnopovezanega sloja ter s kosinusno razdaljo primerjamo razdalje med osebami.

Odločili smo se za uporabo IMDB-WIKI podatkovne baze [20], ki vsebuje fotografije oseb pridobljene iz spletnih strani IMDB ter Wikipedia. Osnovna baza vsebuje slike oseb, kjer je lahko obraz le manjši del celotne fotografije. Uporabljali pa smo različico baze, kjer so slike avtomatsko obrezane tako, da so na slikah samo obrazi.

Zaradi pomanjkanja človeškega nadzora imamo v bazi tudi slike, kjer ni obraza. Vsaka slika je anotirana s parameterom face_score, ki je metrika, ki meri prisotnost obraza na sliki. Na ta parameter se zanašamo, da iz baze odstrani slike, ki za naš namen niso primerne, saj ne vsebujejo jasno vidnega obraza. Želeli smo spodnjo mejo za to vrednost, da bi imeli dobro razmerje med številom obdržanih slik ter kvaliteto le-teh. Mejo smo eksperimentalno 


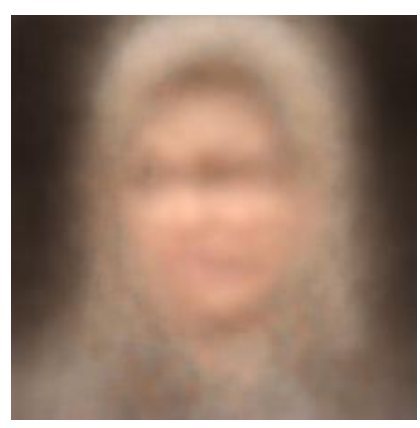

Slika 3.10: Generirane slike, kadar učna množica ni vsebovala poravnanih slik.

nastavili na 3 .

Preden smo zgradili celotni model s kritikom, smo preizkusili novo podatkovno bazo kot učno množico za konvolucijski variacijski avtoenkoder, predstavljen v tem podpoglavju 3.4.2. Kmalu smo ugotovili, da je kvaliteta generiranih slik precej slabša kot pri uporabi UTKFace [37] baze. Razlog je predvem v tem, da so tam slike že predhodno poravnane. Kazalo je, da je neporavnanost slik velik problem, saj nam je mreža generirala slike, ki so bile popolnoma neostre, primer vidimo na sliki 3.10.

Izgledalo je, da ima mreža težave pri učenju obraza, kadar so obrazi na učnih slikah različnih dimenzij, pozicij, osvetlitev in velikosti. Da bi lahko podatkovno bazo uporabljali za naš generativni model, smo potrebovali poravnavo obrazov v naši učni množici. Uporabili smo metodo za zaznavanje Dlib [38], to je prednaučeni model, ki nam poda informacije o lastnostih ključnih elementov obrazov. V našem primeru potrebujemo zaznati položaj notranjih kotičkov oči ter koncev spodnje ustnice. Slike bodo poravnane, ko bodo zaznani elementi na istem mestu na vseh slikah v množici. To storimo z linearnimi transformacijami, ki točke projicirajo na isto mesto. Do težav sicer pride pri slikah, kjer so osebe fotografirane iz strani, saj projekcija precej pokvari kvaliteto slike, vendar je to potreben kompromis za uporabo naše podatkovne baze. Take slike bi sicer lahko ročno odstranili iz podatkovne baze, vendar bi to bilo zaradi števila slik (500.000) časovno preveč potra- 
tno. Do neke mere smo take slike odstranili s pomočjo filtriranja glede na face_score parameter.

Ko smo imeli poravnane obrazne slike, smo morali uporabiti poravnane slike za učenje klasifikatorja, ki se bo uporabljal kot naš kritik. V bazi smo najprej morali določiti osebe, za katere smo imeli na voljo zadostno število različnih fotografij, saj le tako lahko pravilno naučimo identitetni klasifikator. Tudi tukaj smo morali določiti, koliko slik iste osebe potrebujemo, da pravilno naučimo identifikacijo obrazov. Izbrali smo mejo vsaj 75 slik na osebo, kar naj bi glede na prejšnje izkušnje zadostovalo za učenje klasifikatorja ter ohranilo zadostno število fotografij v bazi, da je učenje variacijskega avtoenkoderja še vedno mogoče.

Najprej smo se odločili za učenje Squeezenet arhitekture, vendar nam ni uspelo doseči konvergence. Poizkušali smo z različnimi parametri za število slik na osebo, poizkušali smo z dodatno normalizacijo, vendar se natančnost klasifikacije ni povzpela prek $10 \%$. Podobno je bilo pri VGG-16 arhitekturi, kjer so se pojavile popolnoma iste težave pri učenju klasifikatorja. Predvidevamo, da je največji razlog slaba kvaliteta slik v učni množici, kar onemogoča klasifikatorju, da bi dosegel konvergenco.

Več uspeha smo imeli z učenjem Inception-V3 klasifikatorja. Tukaj je konvergenca lepo napredovala in dobili smo približno 90 odstotno klasifikacijsko natančnost. Za naše namene bi moralo to zadostovati, saj je naloga klasifikatorja, da se vede kot kritik in samo usmerja učenje v pravo smer.

Naš model smo torej sestavili iz konvolucijskega variacijskega avtoenkoderja povezanega s kritikom, zgrajenim s pomočjo Inception-V3 arhitekture. Poizkušali smo pravilno utežiti razmerje med kriterijem kritika, rekonstrukcijo napako ter KL divergenco, vendar nam ni uspelo pridobiti rezultatov, ki bi izboljšali naše generirane slike. Ob manjši utežitvi kritika so generirane slike bile popolnoma iste kot pri modelu, kjer kritik ni dodan. Ob večji utežitvi pa so se znova začeli pojavljati artefakti. Sicer ti niso bili tako močno opazni kot pri prejšnjih pristopih, vendar je bila njihova prisotnost vseeno vidna. 
Zaradi spremembe baze, se je precej poslabšala tudi kvaliteta generiranih obrazov, saj je kvaliteta slik v bazi precej slabša. Problem je predstavljalo tudi generiranje najbolj mladih oz. starih obrazov. Težava nastane zaradi neuravnoteženosti baze v smislu starostnih porazdelitev. Ker so slike pobrane iz strani IMDB in Wikipedije, imamo v bazi zelo malo slik otrok, saj je relativno gledano precej manjša možnost, da nastopajo kot igralci oz. so dovolj znani/pomembni, da bi imeli svojo stran na spletni enciklopediji Wikipedia.

Zaradi omenjenih težav in neuspešnega poskusa z uvedbo kritika, ki ga naučimo sami, smo se odločili, da se vrnemo na uporabo UTKFace podatkovne baze in poizkusimo $\mathrm{z}$ alternativnimi pristopi.

\section{Variacijski avtoenkoder s konsistentimi globokimi značilkami}

Implementirali in preizkusili smo delovanje še ene razširitve klasičnega variacijskega avtoenkoderja in sicer variacijski avtoenkoder s konsistentinimi globokimi značilkami (angl. deep feature consistent - DFC) [39]. V članku avtorji predstavijo postopek, pri katerem spremenijo klasično kriterijsko funkcijo variacijskega avtoenkoderja tako, da navadno rekonstrukcijsko napako zamenjajo s kriterijem ujemanja globokih značilk. Koliko sta si dve sliki podobni lahko definiramo skozi ujemanje značilk, ki se pojavljajo v notranjih slojih nevronskih mrež. Želimo poiskati podobnosti med globokimi reprezentacijami slike. Naj $\Phi(x)^{l}$ predstavljajo vrednosti v l-tem skritem sloju nevronske mreže $\Phi$ pri vhodu $x$. Matematično gledano je $\Phi(x)^{l}$ 3-dimenzionalni kvader oblike $\left[C^{l} \times W^{l} \times H^{l}\right]$, kjer $C^{l}$ predstavlja število filtrov, $W^{l}$ in $H^{l}$ pa širino in višino značilk na $l$-tem nivoju konvolucijske mreže. Kriterijsko funkcijo za en sloj $\left(\mathcal{L}_{\text {rec }}^{l}\right)$ lahko definiramo kot evklidsko razdaljo med dvema slojema. Velja torej:

$$
\mathcal{L}_{\mathrm{rec}}^{l}(x, \hat{x})=\frac{1}{2 C^{l} W^{l} H^{l}} \sum_{c=1}^{C^{l}} \sum_{w=1}^{W^{l}} \sum_{h=1}^{H^{l}}\left(\Phi(x)_{c, w, h}^{l}-\Phi\left(\hat{x}_{c, w, h}^{l}\right)^{2} .\right.
$$

Končna rekonstrukcijska napaka je definirana kot vsota takih enoslojnih 
rekonstrukcijskih napak:

$$
L_{\mathrm{rec}}=\sum_{l} \mathcal{L}_{\mathrm{rec}}^{l}
$$

Za učenje variacijskega avtoenkoderja moramo skupaj minimizirati KL divergenco ter rekonstrukcijsko napako (3.12). Skupna kriterijska funkcija je torej:

$$
\mathcal{L}=\alpha \mathcal{L}_{k l}+\beta \sum_{i}^{l} \mathcal{L}_{r e c}^{l},
$$

kjer sta $\alpha$ in $\beta$ uteži, ki določata, kateremu delu bomo dali več pomembnosti.

Zanimalo nas je, če bi novo definirani $\mathcal{L}_{\text {rec }}$ lahko uporabili kot dodatno kriterijsko funkcijo za ohranjanje identitete. Pustili bi klasično rekonstrukcijsko napako ter dodali novo napako, ki naj bi bila zadolžena za primerjanje identitete med dvema obrazoma. S tem bi poizkušali še bolj posplošiti pristop s kritikom. Definirali smo novo kriterijsko funkcijo, ki jo zapišemo:

$$
\mathcal{L}=\alpha \mathcal{L}_{k l}+\beta \mathcal{L}_{r e c}+\gamma \sum_{i}^{l}\left(\mathcal{L}_{r e c}^{l}\right)
$$

Kot so to storili avtorji v članku, smo želeli metodo preizkusiti na VGG16 in VGG-19 arhitekturah. Implementirali smo več različnih verzij DFC kritika. Pomembno je število oz. izbira notranjih slojev, ki jih primerjamo med sabo. Naredili smo tri različice:

- VAE-123, kjer smo med sabo primerjali prve tri konvolucijske bloke v VGG mreži.

- VAE-456, kjer smo med sabo primerjali zadnje tri konvolucijske bloke v VGG mreži.

- VAE-all, kjer smo primerjali vse konvolucijske bloke med sabo.

Pomembno je, na kakšnih podatkih je naučena VGG mreža. Najprej smo metodo preizkusili na prednaučeni mreži [32], ki smo jo uporabljali že zgoraj v tem podpoglavju. Implementacijo mreže je bilo potrebno nadgraditi tako, da smo namesto končnega sloja vračali podatke iz potrebnih notranjih slojev. 
Vsako od slik učne množice smo dali na vhod tej mreži ter dobili seznam vektorjev potrebnih notranjih slojev. Poleg vhodne slike ter starosti smo to uporabljali kot dodatni vhod našega celotnega modela, da smo lahko te podatke uporabljali v naši kriterijski funkciji. Kot vidimo v enačbi (3.11), je potrebno vsakega od upoštevanih slojev primerno normalizirati glede na njegovo velikost. Zaradi notranjih omejitev knjižnice Keras, v kriterijski funkciji ni bilo mogoče dostopati do dimenzije trenutnega tenzorja. Uteževanje smo naredili ročno, tako da smo predhodno dobili dimenzije notranjih slojev, si to vrednost zapomnili ter končni sloj utežili s primerno fiksno prednastavljeno vrednostjo. Pristop je ekvivalenten, vendar zahteva ročno spreminjanje uteži, kadar spremenimo vhodne dimenzije našega modela.

$\mathrm{V}$ [39] je omenjeno, da med učenjem uporabljamo KL divergenco za učenje enkoderja ter rekonstrukcijsko napako za učenje tako enkoderja kot dekoderja. Implementacijsko gledano moramo v knjižnici Keras ustvariti dva modela. Prvi je zadolžen za učenje s pomočjo KL divergence in vsebuje samo sloje enkoderja, drugi pa posodablja celotno mrežo s pomočjo rekonstrukcijske napake. V našem primeru smo kot rekonstrukcijsko napako definirali uteženo razmerje med klasično rekonstrukcijsko napako osnovano na primerjavi posameznih slikovnih točk ter med novo uvedeno primerjavo globokih značilk.

Mrežo smo učili s pomočjo optimizatorja ADAM z učno hitrostjo oz. faktorjem učenja 0,0005. Ostali parametri so ostali isti kot pri implementaciji klasičnega variacijskega avtoenkoderja. Zaradi nezadovoljivih rezultatov dobljenih s pomočjo tega pristopa, kjer so slike delovale nerealistično, smo najprej želeli spremeniti prednaučenega kritika. V [39] je omenjeno, da so avtorji uporabljali mrežo, ki je bila učena s pomočjo ImageNet [40] podatkovne množice.

Orodje Keras ima notranjo implementacijo VGG-16 ter VGG-19 arhitektur, ki uporabljajo prednaučene ImageNet uteži. Ker ta ne omogoča dostopa do notranjih slojev, smo njihovo implementacijo nadgradili z dodatnim parametrom, ki je omogočal dostop do notranjih slojev nevronske mreže. 


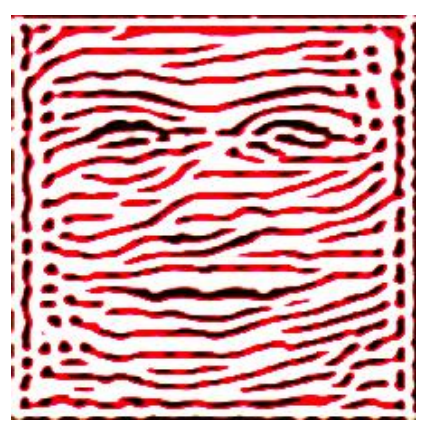

Slika 3.11: Podoba obrazov, ki spominja na risanke.

Rezultati niso bili takšni, kot bi si jih želeli, saj so obrazi izgledali kot narisani, kar vidimo na sliki 3.11. Zato smo se odločili preizkusiti še implementacijo, ki je bila definirana v članku [39], kjer imamo samo eno rekonstrukcijsko napako, osnovano na primerjavi notranjih slojev. Ostale implementacijske podrobnosti so ostale enake. Kljub temu se naši rezultati niso izboljšali.

\subsection{Avtoenkoder}

\subsubsection{Teoretično ozadje}

Teoretično ozadje smo podrobneje predhodno predstavili že v podpoglavjih 2.1 in 2.4 pri pregledu področja. Klasični avtoenkoder je teoretično zelo omejen kot generativni model, saj lahko latentne vektorje dobimo le s kodiranjem obstoječe slike. Če želimo spremeniti eno od lastnosti slike s spreminjanjem latentnega vektorja, nimamo nikakršnega zagotovila o končnem rezultatu. Nasprotniški avtoenkoder je precej podoben model kot variacijski avtoenkoder. Sprememba je predvsem v tem, kakšne mehanizme uporabljamo za zagotavljanje normalne porazdelitve v latentnemu vektorju. Pri variacijskem avtoenkoderju za to uporabljamo kriterijsko funkcijo, ki je mešanica med KL divergenco in rekonstrukcijsko napako, medtem ko pri nasprotniških avtoenkoderjih za to skrbi nasprotniško učenje, kjer je diskriminator zadolžen za uveljavljanje pravilne porazdelitve. 


\subsubsection{Implementacija}

Zaradi nezadovoljivih rezultatov, vidnih v podpoglavju 4.2.4, dobljenih $\mathrm{s}$ pomočjo različic variacijskih avtoenkoderjev, smo začeli raziskovati možne inačice avtoenkoderjev. Najprej smo naredili povsem klasičen pogojni konvolucijski avtoenkoder, kot je viden na sliki 3.12 .

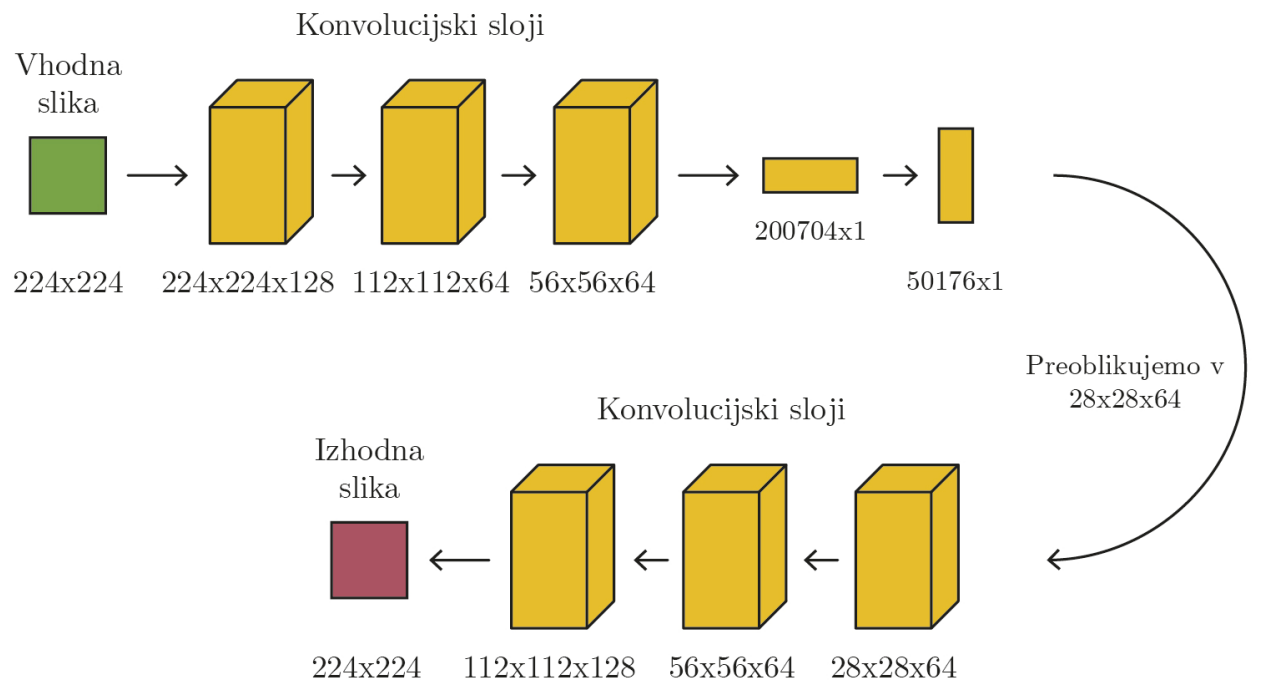

Slika 3.12: Arhitektura avtoenkoderja.

Uporabljali smo Adadelta optimizator ter binarno navzkrižno entropijo za kriterijsko funkcijo. Našo mrežo smo učili s svežnji velikosti 32 ter postopek učili 30 iteracij po učni množici (angl. epochs). Velikost vhodnih in izhodnih podatkov je v tem primeru povsem nastavljivih, vendar smo kot osnovo izbrali velikost slik $224 \times 224$ slikovnih točk. Pomembna je tudi velikost latentnega vektorja, ki smo jo nastavili na 64, kjer je zadnjih 10 elementov vektorja zadolženih za shranjevanje informacije, ki določa starostni razred.

Implementirali smo tudi razširjeno verzijo avtoenkoderja, ki je bila osnova na DFC implementaciji, kjer smo poleg binarne navzkrižne entropije uporabljali tudi rekonstrukcijsko napako po enačbi (3.12). Parametri ter arhitektura je ostala enaka, edina sprememba je v strukturi modela ter v razširitvi kriterijske funkcije. 


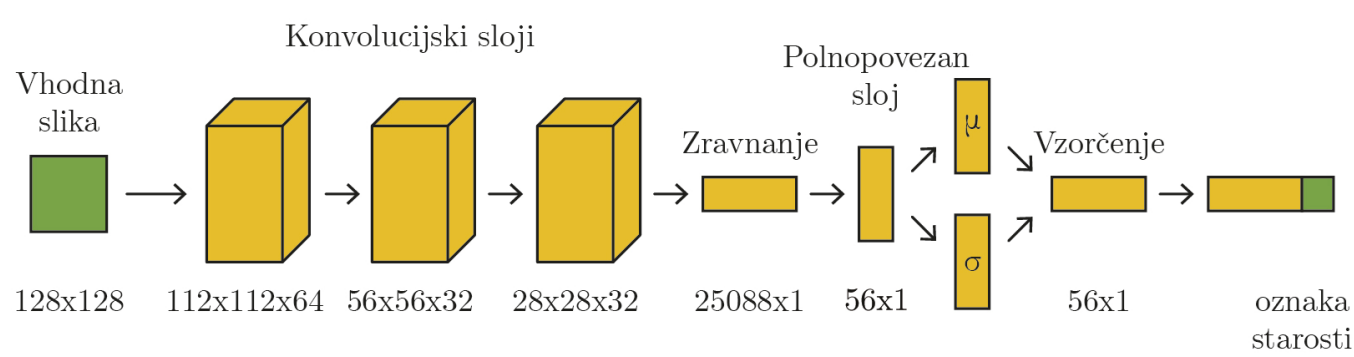

Slika 3.13: Struktura enkoderja v nasprotniškem avtoenkoderju.

\section{Nasprotniški avtoenkoder}

Naredili smo nasprotniški avtoenkoder, osnovan na konvolucijski arhitekturi. Na vhod smo podajali barvne slike velikosti $224 \times 224$ slikovnih točk ter oznake o starosti oseb. V primeru nasprotniškega avtoenkoderja je mreža sestavljena iz treh glavnih delov:

- Enkoder $E$, ki je zadolžen, da se vhodni podatki zakodirajo v latentno reprezentacijo.

- Generator (dekoder) G, ki je zadolžen za generiranje slike iz latentne reprezentacije.

- Diskriminator $D$, ki je zadolžen za ohranjanje enotske naravne porazdelitve latentnega vektorja.

Vsak od teh delov ima svojo arhitekturo. Če pogledamo sliko 3.13 vidimo, da je enkoder sestavljen iz treh zaporednih konvolucijskih slojev, nato pa reprezentacijo sploščimo in iz nje naredimo dva polnopovezana sloja srednje vrednosti ter variance. Uporabljamo torej normalno porazdeljeni enkoder, kot je definiran v enačbi (2.11).

$\mathrm{V}$ vsakem od konvolucijskih slojev uporabljamo velikost jedra $(3,3)$, ter aktivacijo z usmerjeno linearno enoto, in za manjšanje višine in širine uporabljamo koračenje s korakom velikosti 2.

Strukturo dekoderja lahko vidimo na sliki 3.14. Prvi sloj je polnopovezan sloj velikosti 25088. Nato sledijo štirje konvolucijski sloji, med katerimi v 
namene povečanja dimenzije uporabljamo sloj nadvzorčenja (angl. upsampling layer). Za polnopovezani sloj ter za prve tri konvolucijske uporabljamo aktivacijo z usmerjeno linearno enoto, za zadnjega pa uporabljamo sigmoid aktivacijo. Vsa jedra konvolucij so velikosti $3 \times 3$.

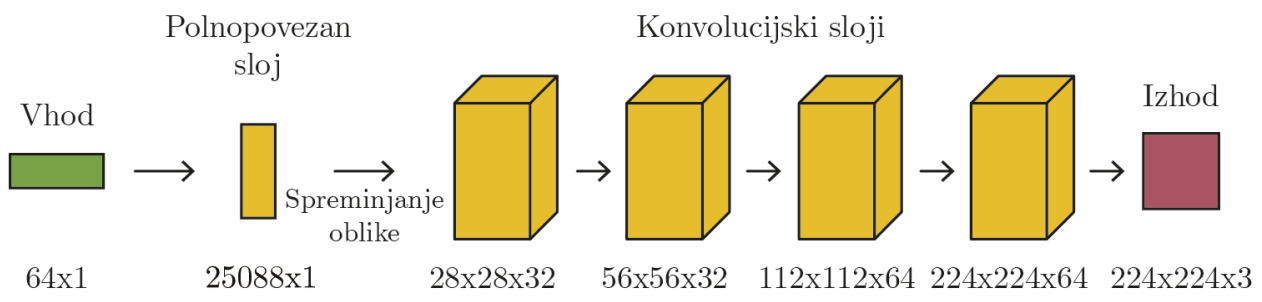

Slika 3.14: Struktura dekoderja v nasprotniškem avtoenkoderju.

Diskriminator ima zelo enostavno strukturo, ki jo lahko vidimo na sliki 3.15 .

$\mathrm{Na}$ vhod dobi latentni vektor, ki ga generira enkoder, nato sledita dva polnopovezana sloja velikosti 512 in 256 nevronov, v katerih uporabljamo aktivacijo s puščajočo usmerjeno linearno enoto. Zadnji sloj je polnopovezan velikosti 1, pri katerem uporabljamo sigmoid aktivacijo.

Učenje poteka v dveh korakih. Najprej učimo diskriminator. Želimo, da nam pove ali je latentni vektor normalno porazdeljen, zato mu med učenjem podajamo normalno porazdeljene vektorje, ki jih mora klasificirati kot pravilne (1) ter ostale, za katere želimo, da jih klasificira kot nepravilne (0).

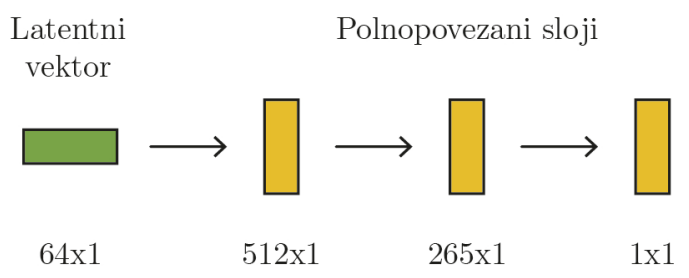

Slika 3.15: Struktura diskriminatorja v nasprotniškem avtoenkoderju. 
Kot kriterijsko funkcijo v modelu diskriminatorja uporabljamo binarno navzkrižno entropijo. Po učenju diskriminatorja učimo še skupni model, ki ga dobimo tako, da sestavimo skupaj vse tri dele. Imamo torej enkoder, ki iz vhodne slike in oznake o starosti ustvari latentno reprezentacijo. To podamo dekoderju, ki nam ustvari rekonstruirano sliko. Latentni vektor podamo diskriminatorju in dobimo veljavnost. Naš model na vhod dobi vhodno sliko in oznako starosti. Na izhod pa vrača rekonstruirano sliko ter veljavnost. Kot kriterijsko funkcijo za rekonstrukcijo uporabljamo MSE:

$$
M S E(Y, \hat{Y})=\frac{1}{n} \sum_{i=1}^{n}\left(Y_{i}-\hat{Y}_{i}\right)^{2} .
$$

\subsubsection{Dodatna optimizacija}

Implementirali smo dodatno optimizacijo identitete, ki je bila omenjena $\mathrm{v}$ [1]. Glavna ideja metode je, da latentno reprezentacijo še bolj optimiziramo iz stališča ohranjanja identitete tako, da uporabimo eno od optimizacijskih metod, ki nam ob začetnem približku konvergira v boljšo rešitev. V članku so idejo uporabljali na primeru generativnih nasprotniških mrež, vendar je težava, da pri generativnih nasprotniških mrežah ne dobimo preslikave iz vhodne slike v latentni vektor, ampak samo obratno. Zato so morali avtorji v članku naučiti dodatno nevronsko mrežo, da se nauči to preslikavo.

Ker v našem primeru uporabljamo avtoenkoder, dodatna nevronska mreža ni potrebna, saj je ena od glavnih lastnosti avtoenkoderjev ravno to, da nam določijo preslikavo med vhodnimi podatki in latentnim prostorom. Določiti moramo metriko, ki je bolj primerna za namene ohranjanja identitete kot klasična primerjava, kjer gledamo razliko na nivoju posameznih slikovnih točk. Odločili smo se, da bomo uporabili VGG-Face arhitekturo, ki je bila prednaučena za klasifikacijo identitet na obraznih slikah [32]. Ko vhodno sliko spustimo skozi to mrežo, lahko iz zadnjega polnopovezanega sloja preberemo vektor značilk, ki nam predstavlja identiteto osebe. V našem primeru za vsako vhodno sliko dobimo vektor značilk velikosti 2048. Kot identitetno razliko med dvema osebama lahko uporabimo kosinusno razdaljo. Celoten 
optimizacijski postopek lahko zapišemo v naslednjih korakih:

1. Vhodno sliko vstavimo v enkoder nasprotniškega avtoenkoderja da dobimo latentno reprezentacijo $z_{0}$.

2. V izbrano optimizacijsko metodo vstavimo $z_{0}$ kot začetni približek.

3. Optimizacijska metoda nam izračuna optimizirani latentni vektor. Vzame trenutno latentno reprezentacijo, s pomočjo dekoderja generira sliko in jo primerja z referenčno sliko. Nato popravi približek in postopek se ponavlja do konvergence.

4. Ko metoda dokonča konvergacijo, dobljeni vektor vstavimo v dekoder ter spreminjamo oznako starosti, da dobimo slike različnih starosti.

Kot optimizacijsko metodo smo preizkusili nekaj standardnih algoritmov, kot so L-BFGS-B, COBYLA, Nelder-Mead [23, 41, 42] ipd. vendar izboljšav nismo dobili. Zgodila sta se dva primera. Pri prvem metoda ni dokončala konvergacije in se je gibala v okolici začetnega približka. Takrat so bile spremembe na sliki povsem neopazne. $\mathrm{V}$ drugem primeru pa je metoda skonvergirala k neki vrednosti, a slike so postale precej zamazane in obrazi deformirani.

\section{Dodatno procesiranje rezultatov}

Ko naša mreža generira sliko obraza, ji s pomočjo dodatnega procesiranja izboljšamo kvaliteto. Največji problem generiranih slik je pomanjkanje ostrine, zato smo se odločili implementirali dodatno ostrenje. Implementacija je povsem enostavna, saj je potrebno le definirati jedro konvolucije, ki bo fotografijo izostrilo:

$$
\left[\begin{array}{ccc}
0 & -1 & 0 \\
-1 & 5 & -1 \\
0 & -1 & 0
\end{array}\right]
$$

Z izbiro jedra je določena moč ostrenja. Če ostrimo premalo, je učinek namreč zanemarljiv, če ostrimo preveč pa na slikah dobimo moteče artefakte. Ker 
so si slike med seboj zelo podobne, smo jedro izbrali s poizkušanjem nekaj jeder in ugotovili, kateri nam poda najboljše rezultate. 


\section{Poglavje 4}

\section{Rezultati}

V poglavju predstavimo vmesne rezultate, ki smo jih prodobili pri implementaciji vseh modelov ter evalvacijo končnih rezultatov s pomočjo ankete. Prav tako predstavimo uporabljene podatkovne baze ter definiramo uporabljen eksperimentalni protokol.

\subsection{Podatkovna baza ter eksperimentalni protokol}

Pri učenju vseh arhitektur in modelov, razen tam kjer je specifično navedeno drugače, smo za učno množico uporabljali bazo slik UTKFace [37], ki vsebuje približno 20.000 slik oseb različnih etničnih izvorov, spola ter starosti. Slike v bazi so obrezane ter poravnane ter vsebujejo osebe pri različnih osvetlitvah, obraznih mimikah ter stopnjah pokritosti. Pomembna lastnost je porazdelitev starosti v bazi, ki jo uporabljamo za učenje. V tabeli 4.1 vidimo, da je baza neuravnotežena proti starostnim skupinam med 20 in 40 let. Prav tako je manjše število slik ljudi starejših od 70 let, kar pa je za naše potrebe sprejemljivo, saj nam staranje do ekstremnih starosti ni poglavitnega pomena.

Pri implementaciji se je pojavil očiten problem pomanjkanja primerne podatkovne baze za učenje naših modelov. Potrebovali bi podatkovno bazo, ki 
spremlja osebo skozi proces staranja, torej kjer imamo fotografije iste osebe pri različnih starostih. Poleg tega pa bi želeli, da te fotografije osebo dokumentirajo od najmlajših do poznih let. Edina prosto dostopna podatkovna baza, ki se približa tem kriterijem je FG-NET [43], ki pa ima žal

\begin{tabular}{|c|c|}
\hline Starostna skupina & Število slik v bazi \\
\hline $0-10$ & 3062 \\
$10-19$ & 1531 \\
$20-29$ & 7344 \\
$30-39$ & 4537 \\
$40-49$ & 2245 \\
$50-59$ & 2299 \\
$60-69$ & 1318 \\
$70-79$ & 699 \\
$80-89$ & 504 \\
$>90$ & 169 \\
\hline
\end{tabular}

Tabela 4.1: Porazdelitev starosti v bazi UTKFace.

kar nekaj očitnih pomanjkljivosti. Največja od njih je majhna velikost podatkovne baze, saj obsega fotografije le približno 80 različnih oseb ter 1000 fotografij skupno. Prav tako je težava v tem, da je večina fotografij osebe pri različnih starostih posneta $\mathrm{v}$ časovnem intervalu nekaj let, kar nam ne omogoča določanja učinka dolgoročnega staranja.

Ena od podatkovnih baz, ki naj bi zadostila pogojem je Morph [44], ki pa je plačljiva in ni prosto dostopna, zatorej je nismo mogli uporabiti.

Pri evalvaciji rezultatov smo uporabljali podatkovno bazo FG-Net, ki vsebuje slike oseb pri različnih starostih. Za namene naše evalvacije smo za vsako osebo izbrali dve fotografiji, ki sta predstavljali osebo z več kot 10 let časovnega razmika.

Pomembno je omeniti tudi to, da so ljudje fotografirani pri različni osvetlitvi, ozadju ter velikosti obraza na sliki. Ker našo mrežo učimo na podatkovni bazi UTKFace, kjer so obrazi obrezani in poravnani med seboj, smo morali 
fotografije iz FG-Net ročno obrezati ter poravnati, saj v nasprotnem primeru delujemo z različnim tipom fotografij kot v učni množici.

Za evalviranje rezultatov smo sestavili tri različne anketne vprašalnike. Pri prvem vprašalniku smo osebam kazali par slik, kjer je prva bila referenčna slika, za drugo pa je veljalo, da je z verjetnostjo 0,5 naključna generirana slika iste starostne skupine in $\mathrm{z}$ verjetnostjo 0,5 referenčna oseba postarana na to starost.

Pri drugem testu smo imeli samo prave pare, torej referenčno sliko in generirano sliko, ki je bila narejena tako, da smo neko drugo (mlajšo) podobo referenčne osebe postarali s pomočjo naše mreže.

Pri vsakem paru so lahko ocenjavalci izbrali eno od treh možnosti:

- Na slikah nista isti osebi.

- Nisem prepričan.

- Na slikah sta isti osebi.

Pri tretjem testu pa smo kazali generirane slike in ocenjavalci so se morali odločiti, v katero starostno skupino spada oseba na sliki. Pri vseh treh testih je bilo potrebno oceniti 50 parov. Vzorec ljudi, ki so rešili vse tri teste je 10 .

\subsection{Vmesni rezultati}

V tem podpoglavju so predstavljeni vmesni rezultati, ki smo jih dobili ob implementaciji različnih arhitektur opisanih v poglavju 3. Teh rezultatov nismo podrobno evalvirali, saj je bilo že na prvi pogled vidno, da dobljene slike ne izpolnjujejo naših ciljev. Za vsako od arhitektur pogledamo tudi potek učenja, ki je privedel do teh rezultatov.

\subsubsection{Pogojna generativna mreža}

Našo mrežo smo učili skozi 5 prehodov čez učno množico, vendar kot je vidno iz grafa učenja na sliki 4.1, je mreža imela težave s konvergenco in predvsem 
v drugi polovici učenja do vidnih izboljšav ni prišlo.

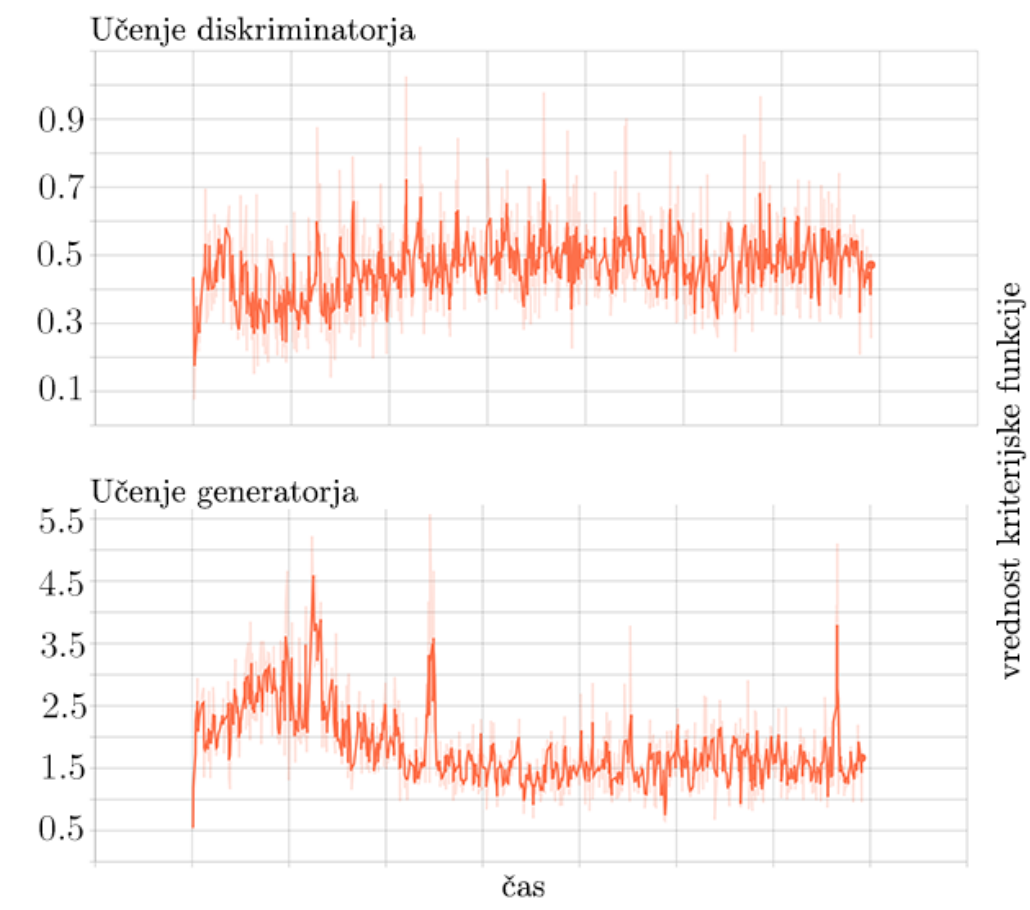

Slika 4.1: Graf učenja CGAN mreže s polnopovezano arhitekturo.

V nadaljnjem delu se je izkazalo, da se težave s konvergenco pojavljajo pri večini generativnih modelov. Prav tako je težko doseči stabilnost, saj majhna sprememba hiperparametrov velikokrat močno vpliva na rezultate učenja. Če pogledamo generirane slike naključnih obrazov določenih starosti (slika 4.2), vidimo, da so dobljene slike zelo šumne.

Opazimo, da je mreži uspelo ujeti informacije o starostnih skupinah, vendar vidimo precej slabšo kvaliteto generiranih slik v določenih starostnih razredih. Razlog je predvsem v tem, da je slik starejših oseb v bazi precej manj kot ostalih, kar privede do neravnovesja $\mathrm{v}$ kvaliteti generiranih obrazov različnih ciljnih starostnih skupin.

Da bi izboljšali vizualno kvaliteto rezultatov, smo poizkusili spremeniti arhitekturo obeh mrež v konvolucijsko obliko, ki je predlagana v [21]. Tudi tukaj se je pokazala nestabilnost osnovnega GAN pristopa. Na naši učni množici je namreč mreža generirala slike, ki so vsebovale samo šum. Kljub 
empiričnem spreminjanju hiperparametrov in upoštevanjem smernic iz literature, nam ni uspelo vzpostaviti delovanja te mreže.

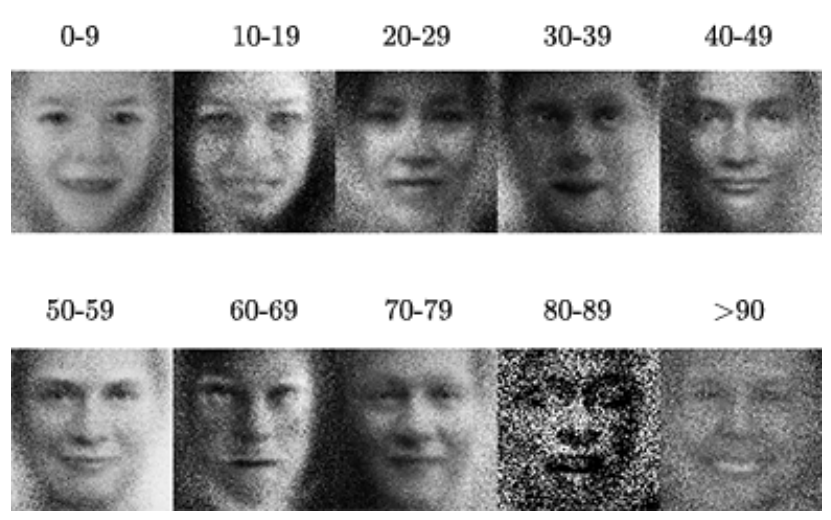

Slika 4.2: Ustvarjene obrazne slike s pomočjo CGAN mreže s polnopovezano arhitekturo.

\subsubsection{Pogojni Wasserstein GAN}

Pri konvolucijskem modelu smo dobili rezultate, ki so prikazani na sliki 4.3. Vidimo, da je bila naša mreža učena na učni množici obraznih slik, vendar

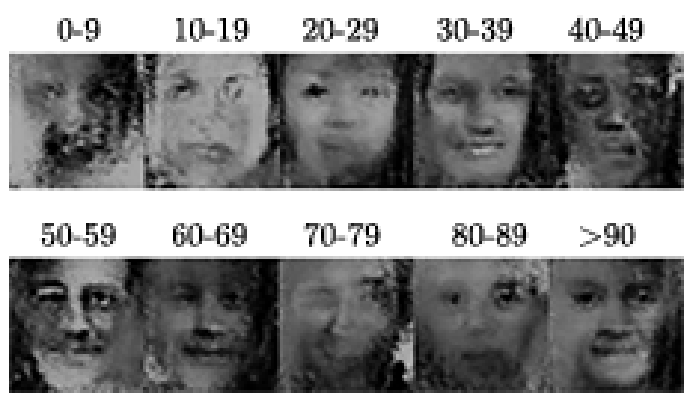

Slika 4.3: Rezultati učenja CWGAN mreže s konvolucijsko arhitekturo.

rezultati niso sprejemljivi, saj so slike zamazane in polne artefaktov. Prav tako so starostni razredi slabo naučeni, saj večina obrazov na slikah na pogled ne pripada pravilni starostni skupini.

Razlog za slab uspeh učenja lahko najdemo na grafu vrednosti kriterijske funkcije, ki je viden na sliki 4.4 . 


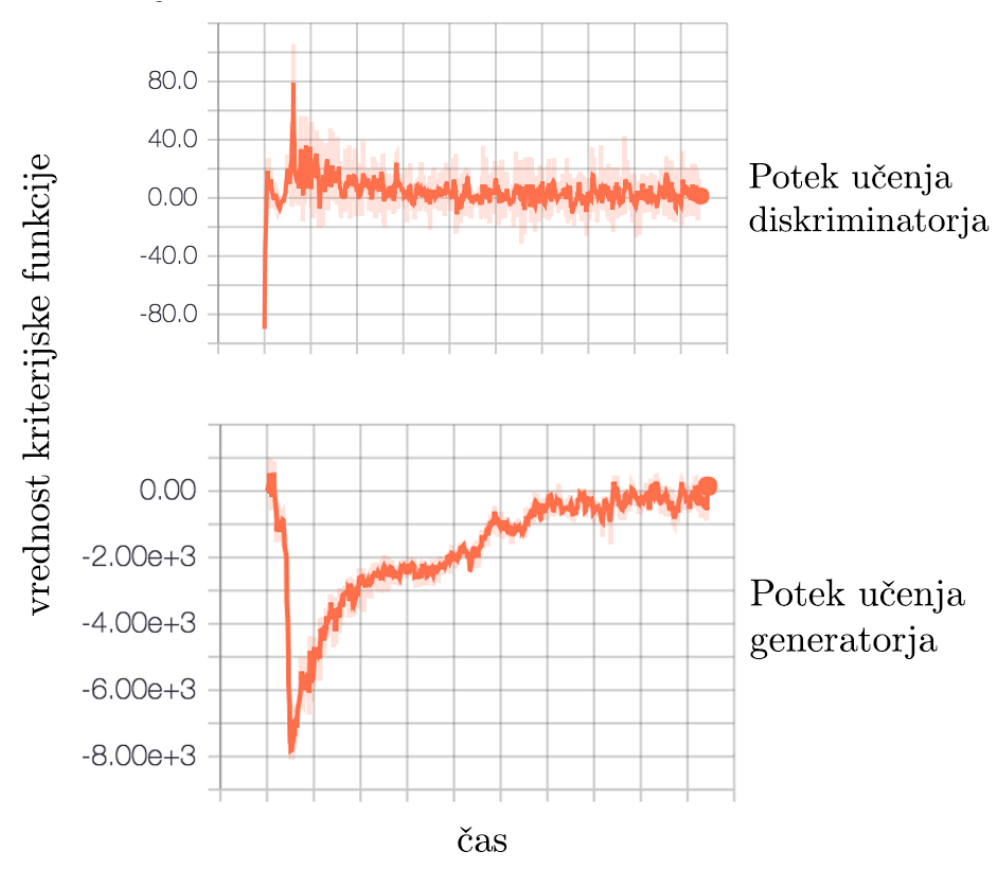

Slika 4.4: Kriterijska funkcija pri učenju konvolucijskega CWGAN modela.

Opazimo, da nam diskriminator zelo hitro konvergira v okolico ničle, vendar se nato tam ne ustali. V času učenja skače po okolici, kar pomeni, da ne pride do nekih večjih vizualnih izboljšanj. Generator pa na začetku učenja dobi izrazito negativno vrednost svoje kriterijske funkcije in se nato počasi približuje ničli, a se tudi on tam ne ustali.

Da bi izboljšali rezultate, smo poizkušali z empiričnim spreminjanjem hiperparametrov (hitrost učenja, $n_{k r i t i k}$, velikost svežnja, število filtrov v konvolucijskih slojih ipd.). Prav tako smo poizkušali dodati osipni (angl. dropout) sloj [45] z različnimi parametri, vendar se rezultati niso vidno izboljšali.

Preizkusili smo tudi uporabo CWGAN arhitekture s polnopovezanimi sloji, kjer generator s pomočjo zaporednih kaskadnih slojev iz vektorja šuma generira sliko, diskriminator pa samo z uporabo le-teh presodi ali je slika prišla iz množice realnih podatkov ali ne. Uporabili smo iste parametre za učenje kot pri konvolucijskem modelu, a smo žal dobili rezultate, ki so bili še manj kvalitetni. Po končanem učenju je večina slik vsebovala le naključni 
šum, kar je vidno na sliki 4.5 .
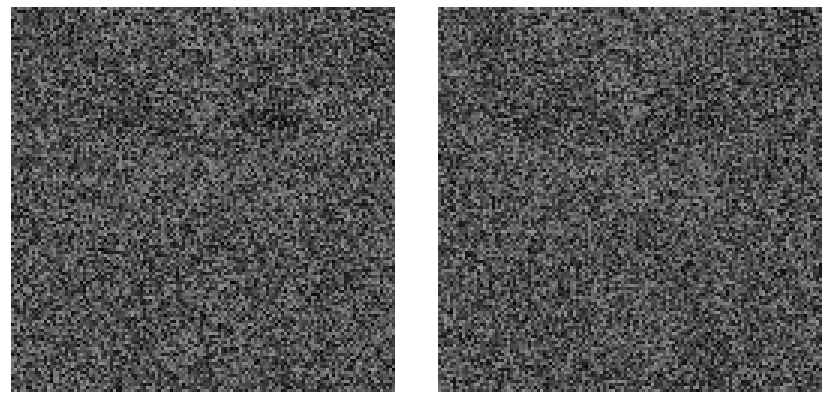

Slika 4.5: Vzorec generiranih slik pri CWGAN modelu s polnopovezanimi sloji.

Če pogledamo potek učenja na sliki 4.6 lahko vidimo, da je v tem primeru

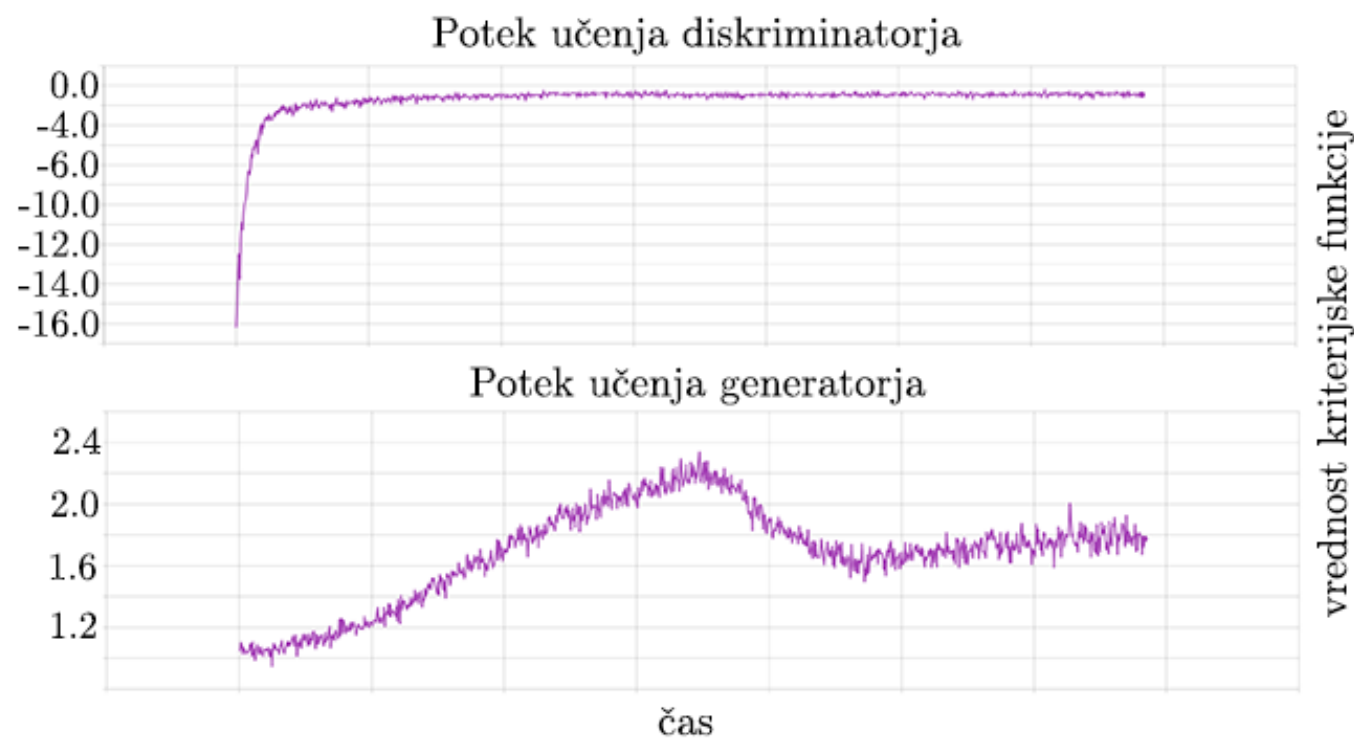

Slika 4.6: Kriterijska funkcija pri učenju CWGAN modela s polnopovezanimi sloji.

diskriminator zelo hitro konvergiral proti optimalni vrednosti 0 , medtem ko kriterijska funkcija generatorja ni konvergirala. To nam lepo prikaže najbolj klasično težavo pri učenju GAN modelov in sicer neravnovesje v moči med diskriminatorjem $D$ in generatorjem $G$. V tem primeru je $D$ postal tako 
dober, da ga $G$ ni znal prelisičiti in medsebojno učenje ni bilo uspešno. Poizkusili smo z empiričnim spreminjanjem parametrov, da bi izboljšali rezultate učenja, vendar željenega cilja nismo mogli doseči.

\subsubsection{BICOGAN}

Rezultati, ki smo jih dobili, so prikazali solidne vizualne rezultate s strani generatorja, kar vidimo na sliki 4.7. Težave so nastale pri enkoderju. Ni nam uspelo, da bi se enkoder pravilno naučil preslikave iz $x \mathrm{v} z$. Veljati bi namreč moralo, $G(E(x)) \sim x$, vendar je iz generiranih slik očitno, da to ni uspelo. Na sliki 4.8 na levem delu vidimo naš $x$ in na desnem vidimo $G(E(x))$. V idealnem primeru, bi bili sliki identični oz. zelo podobni, vendar vidimo, da je razlika prevelika.

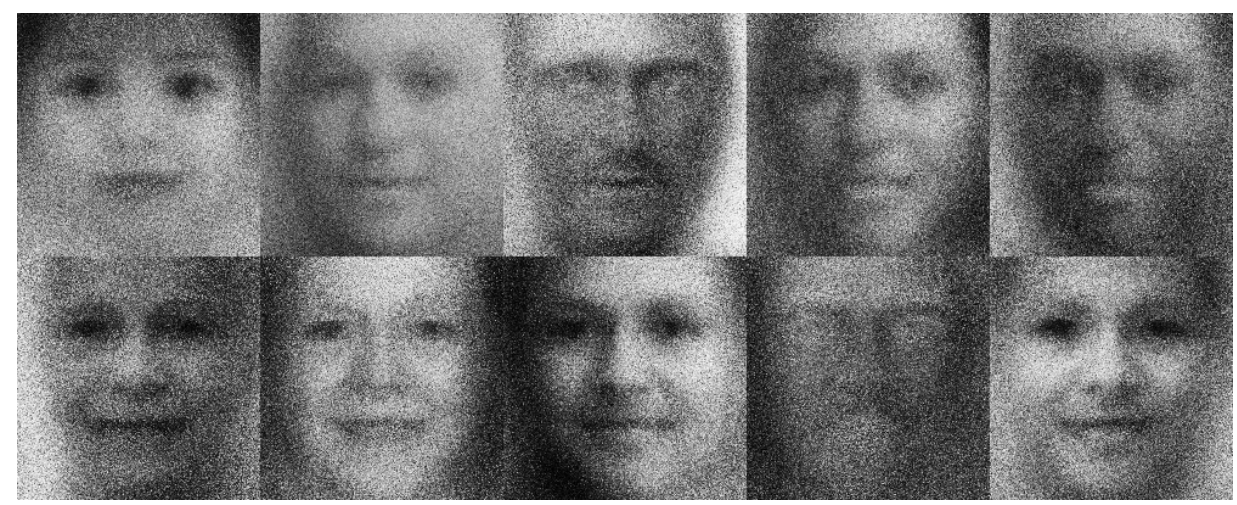

Slika 4.7: Obrazi ustvarjeni s pomočjo BICOGAN mreže.

Še ena od težav je, da arhitektura s polnopovezanimi sloji generira slike, ki so polne šuma in zatorej precej različne od realnih podatkov.

Težave, ki se pojavljalo pri učenju BICOGAN modelov, so istega tipa kot pri učenju klasičnih GAN mrež, vendar so zaradi narave mreže še bolj potencirane. Ker smo sedaj v mrežo vključili še enkoder, postane naša mreža še bolj občutljiva na nastavljanje hiperparametrov. Velja namreč, da zelo hitro pride do neravnovesja med tremi glavnimi komponentami mreže. V takem primeru skozi nasprotniško učenje težko dosežemo optimalno rešitev, saj ena od mrež prevlada nad ostalimi. Kot vidimo na grafih slike 4.9 kriterijske 


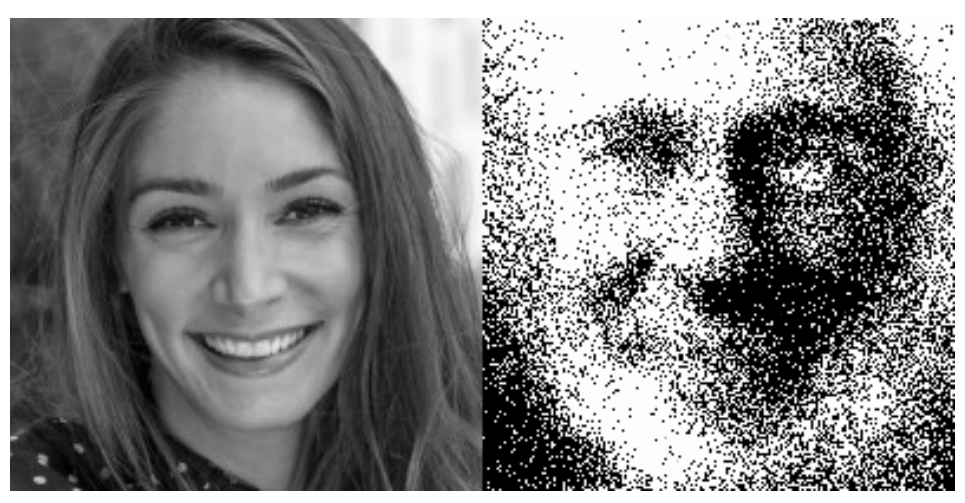

Slika 4.8: Leva slika predstavlja naš $x$, desna pa naš $G(E(X))$.

funkcije generatorja in diskriminatorja, do konvergence ne pride. Opazimo pa, da sta si grafa približno zrcalna preko x-osi. To nam potrjuje nasprotniško učenje teh dveh mrež. Kadar ena od mrež postane močnejša, druga postane šibkejša.

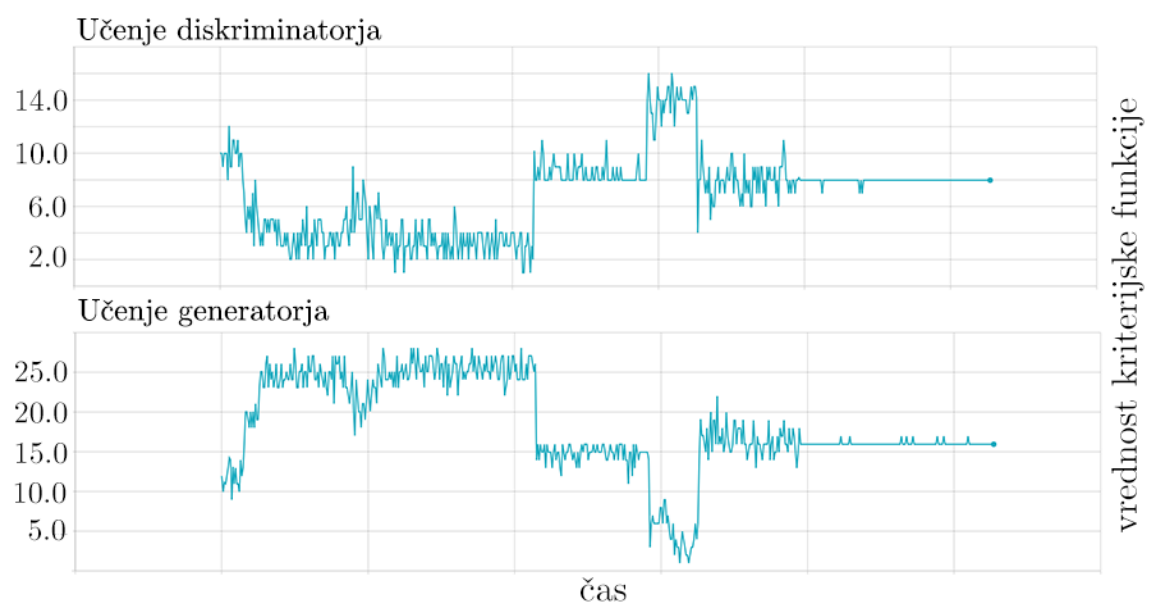

Slika 4.9: Učenje diskriminatorja in generatorja BICOGAN mreže.

\subsubsection{Variacijski avtoenkoder}

\section{Polnopovezana arhitektura}

Najprej smo poizkusili z učenjem polnopovezane arhitekture variacijskega avtoenkoderja. Že takoj smo opazili, da je učenje precej bolj stabilno. Kot 
vidimo na sliki 4.10, nam obe kriterijski funkciji konvergirata proti neki vrednosti, brez večjih variacij. Poleg stabilnejšega poteka učenja pa imamo tudi

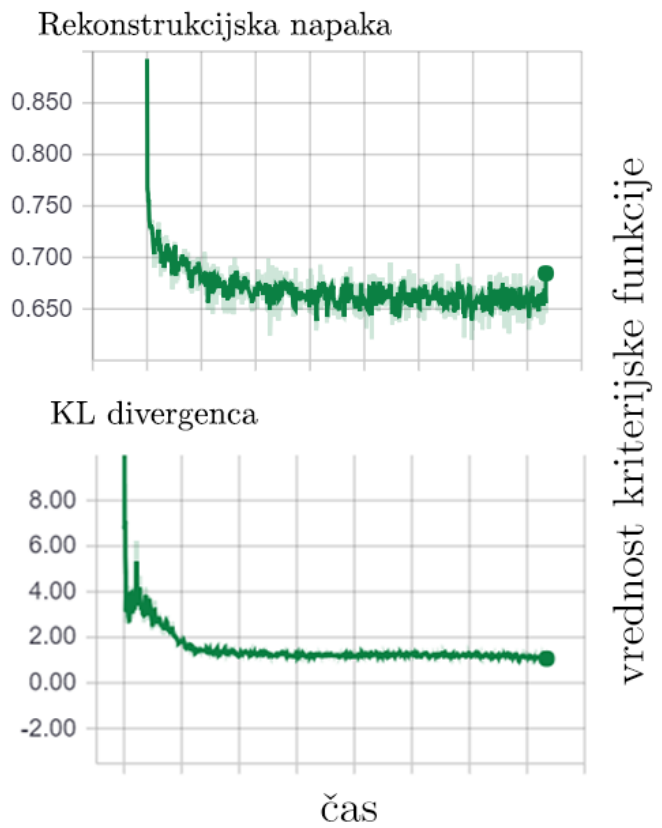

Slika 4.10: Potek učenja variacijskega avtoenkoderja s polnopovezanimi sloji.

precej boljšo kvaliteto generiranih obraznih slik, kar jasno vidimo na sliki 4.11

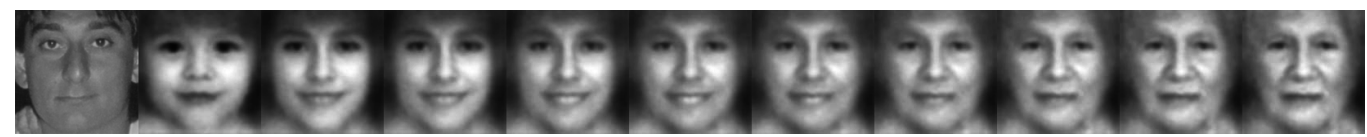

Slika 4.11: Primer obraznih slik generiranih s pomočjo polnopovezanega variacijskega avtoenkoderja.

Najbolj leva slika je referenčna slika, ki smo jo avtoenkoderju podali na vhod. Kot vidimo, je kvaliteta generiranih slik precej dobra, težava pa nastane pri ohranjanju identitete. Generirani obrazi po identiteti niso podobni vhodni sliki, kar je eden od ciljev našega pristopa. 


\section{Konvolucijska arhitektura}

Poizkusili smo tudi s konvolucijsko arhitekturo variacijskega avtoenkoderja, saj je le-ta bolj primerna za generiranje slik. Poleg tega smo želeli spremeniti naše generirane slike $\mathrm{v}$ barvne, saj smo želeli generirati čim bolj realistične obraze.

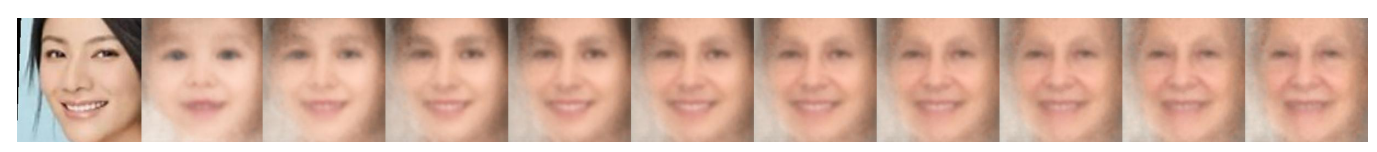

Slika 4.12: Primer obraznih slik generiranih s pomočjo konvolucijskega variacijskega avtoenkoderja.

Zadovoljni smo bili s kvaliteto generiranih fotografij, ki jih vidimo na sliki 4.12, vendar je težava ista kot pri polnopovezani arhitekturi, saj vidimo, da se identiteta osebe izgubi, a vendar v manjši meri kot v prejšnjem primeru. Vidimo pa, da našemu variacijskemu avtoenkoderju uspe ohraniti generalno pozo osebe. Na sliki 4.12 je najbolj leva slika vhodna, ostale pa so bile generirane s pomočjo mreže. Kar je vidno je dejstvo, da so vsi obrazi orientirani na isti način, kot je orientirana referenčna slika.

\section{Konvolucijska arhitektura s kritikom identitete}

Za prvo inačico te arhitekture smo za učenje uporabljali standardno bazo UTKFace ter prednaučenega kritika. Vendar smo dobili rezultate, kjer so bile slike polne arftefaktov, kot je vidno na sliki 4.13 .

Opazimo tudi, da se učinek staranja zmanjša, saj generirani obrazi ne izgledajo pravilnih starosti. Poleg tega opazimo, da nam kritik ni pomagal pri ohranjanju identitetnih lastnosti vhodne slike, saj so generirane slike izgubile izvorno identiteto. Poizkušali smo s spreminjanjem uteževanja moči kritika v sklopu kriterijske funkcije. Vendar ob večji utežitvi kritika dobimo še več artefaktov na generiranih slikah, kar vidimo na sliki 4.14 .

Glede na videne slike predpostavljamo, da se naša nevronska mreža namesto uveljavljanja identitete uči odzive filtrov konvolucijskih slojev. To 


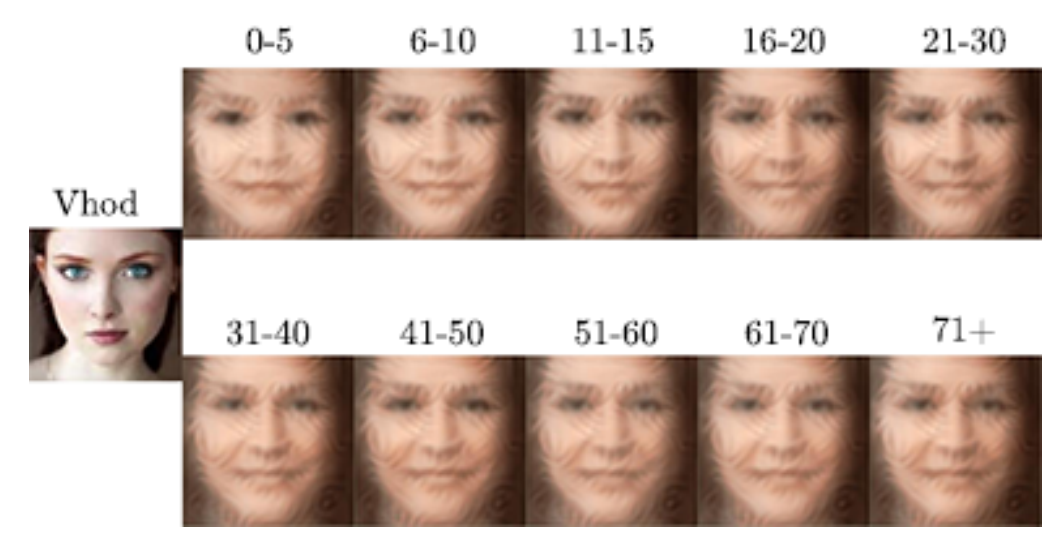

Slika 4.13: Primer obraznih slik generiranih z variacijskim avtoenkoderjem s kritikom identitete.

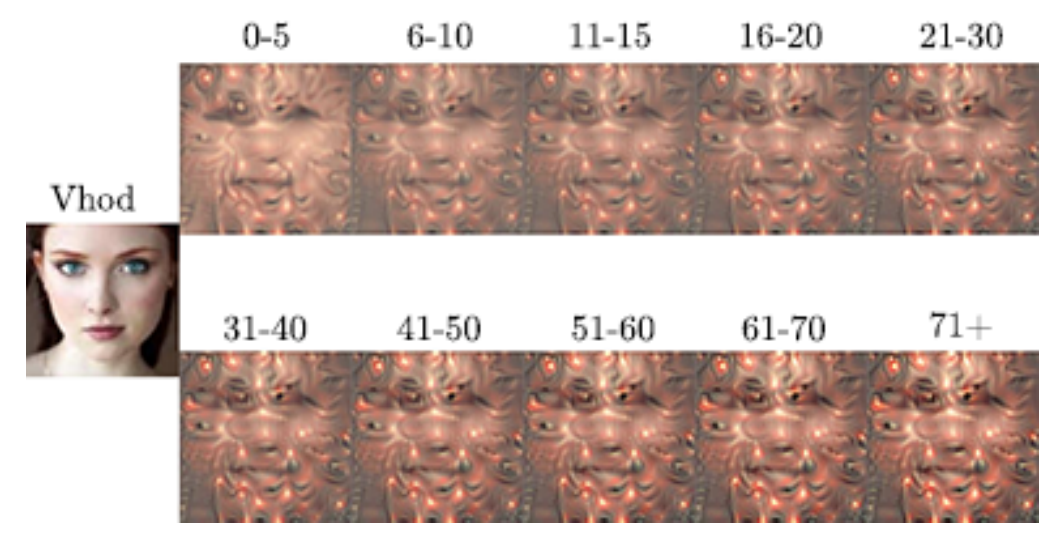

Slika 4.14: Artefakti na slikah pri povečani teži kritika.

nam poda rezultat, ki je podoben tistemu, ki ga vidimo pri Googlovem Deep Dream [46]. Poizkusili smo kritika naučiti na isti bazi kot poteka učenje, saj smo menili, da se bomo tako znebili artefaktov, ki so predstavljeni zgoraj. Arhitekturo Inception-V3 smo kot klasifikator naučili na tej bazi, prav tako pa smo na njej opravljali učenje celotnega modela. Artefakti na slikah so ostali, prav tako pa se je močno poslabšala kvaliteta generiranih obrazov, zato smo ta pristop opustili.

Skupna kriterijska funkcija na sliki 4.15 je sicer med učenjem stabilno konvergirala proti neki vrednosti, vendar od začetka do konca do večjih iz- 
boljšanj ni prišlo.

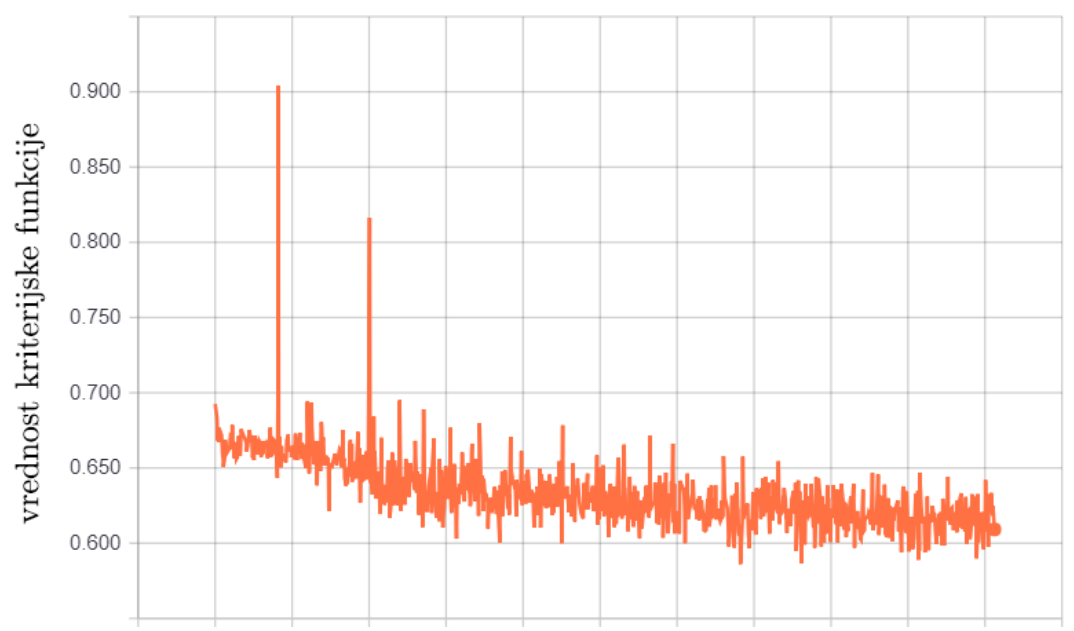

čas

Slika 4.15: Skupna kriterijska funkcija pri učenju s kritikom identitete.

\section{Variacijski avtoenkoder s konsistentimi globokimi značilkami}

Ko pogledamo kriterijsko funkcijo učenja DFC variacijskega avtoenkoderja na sliki 4.16 vidimo, da je imela naša mreža velike težave s konvergenco. To je veljalo za vse različne načine izgradnje DFC modelov in kombinacij, ki so omenjene v poglavju 3.4.2 o implementaciji.

V skladu z obnašanjem učenja je tudi kvaliteta generiranih slik zelo slaba. Različne variacije našega modela so nam podale različne tipe generiranih obrazov, vendar so imeli vsi podoben stil. Veljalo je namreč, da so generirane slike imele poudarjene robove ter izgled, ki ni bil fotorealističen, ampak se je približeval izgledu ilustracij. Na sliki 4.17 vidimo vzorec različnih tipov generiranih obrazov. Za večino od njih dobro vidimo, da so na slikah obrazi, vendar je izgled popolnoma neprimeren za naše namene. Kljub spreminjanju različnih parametrov našega modela, smo dobili samo različne variacije takega izgleda, ni pa nam uspelo generirati fotorealističnih slik. 


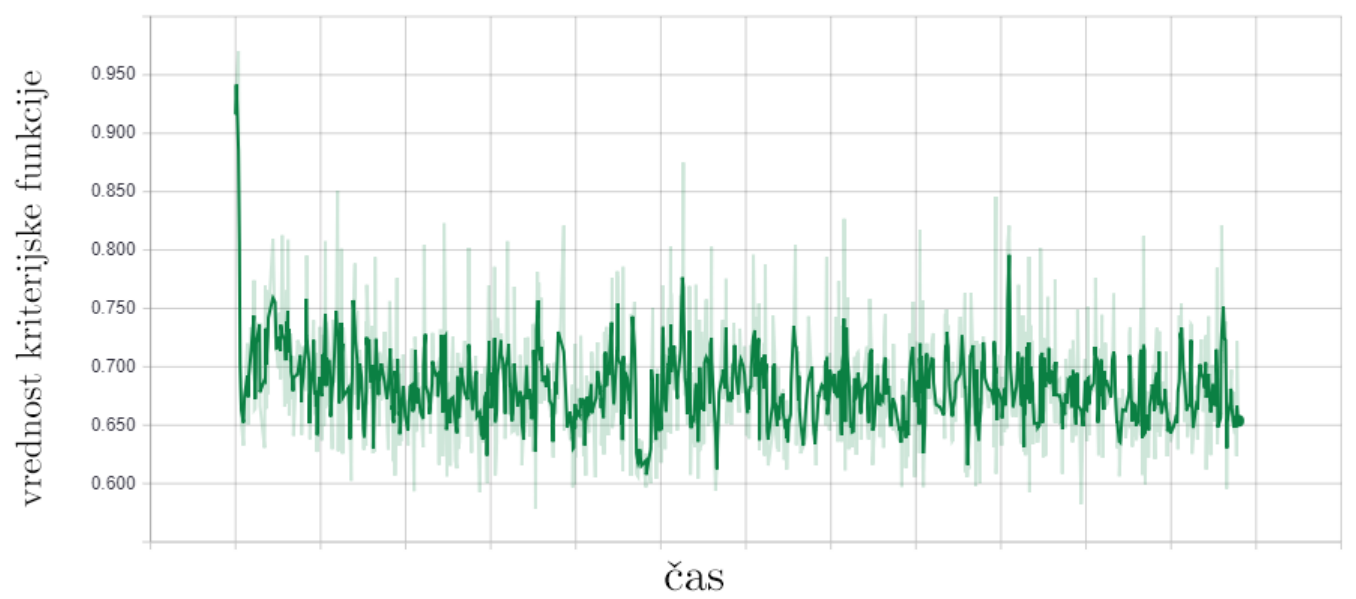

Slika 4.16: Skupna kriterijska funkcija pri učenju DFC variacijskega avtoenkoderja.

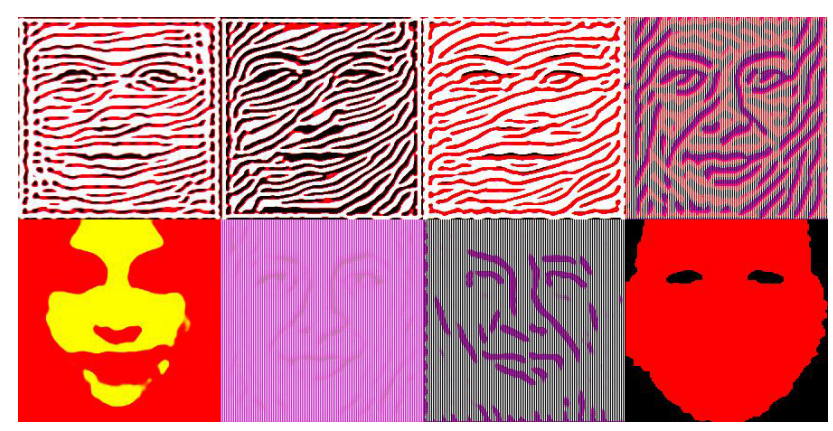

Slika 4.17: Primeri generiranih obrazov z DFC variacijskim avtoenkoderjem.

\subsubsection{Avtoenkoder}

Pri klasičnem pogojnem avtoenkoderju smo dobili rezultate, ki so precej dobro ohranjali identiteto, vendar je bila težava v kvaliteti izgleda samih slik ter pri generiranih slikah mlajših starostnih skupin, kar je opazno na sliki 4.18. Vidimo, da je naši mreži precej uspelo ohraniti glavne identitetne lastnosti vhodne slike. Pomembno je omeniti, da so za določene vhode generirane slike še slabše vizualne kvalitete, kot vidimo v primeru na sliki 4.19. Zelo pomembna je oblika vhoda. Ker učimo na podatkovni bazi, kjer so vsi obrazi poravnani, vsa odstopanja od normalne postavitve obraza privedejo do težav 


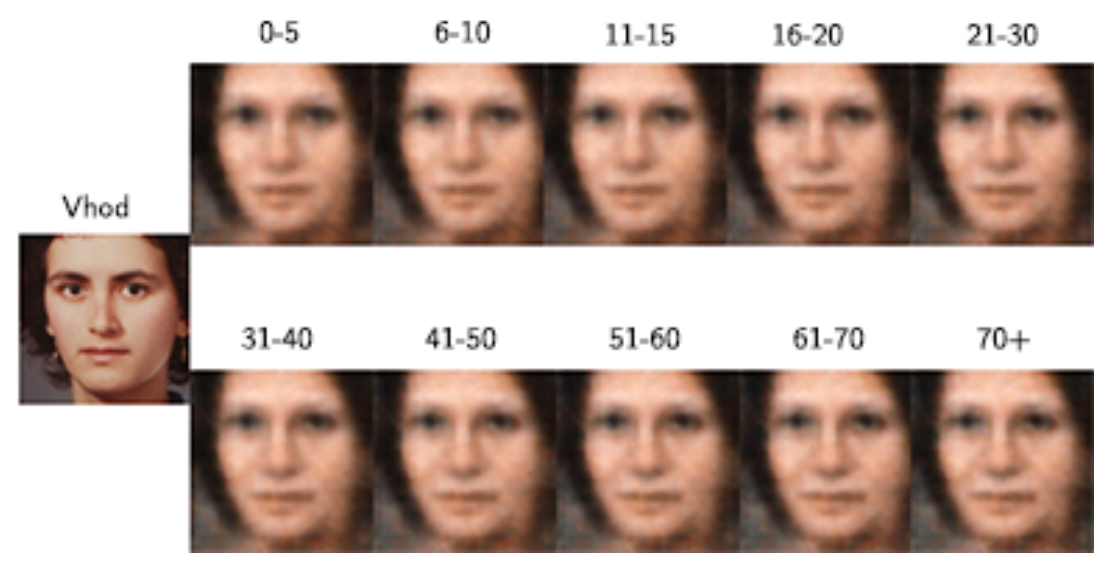

Slika 4.18: Obrazi ustvarjeni s pomočjo pogojnega avtoenkoderja.

pri generiranju slik. Prav tako našo mrežo zmede različna barvna toplota na slikah in podobni vizualni elementi.

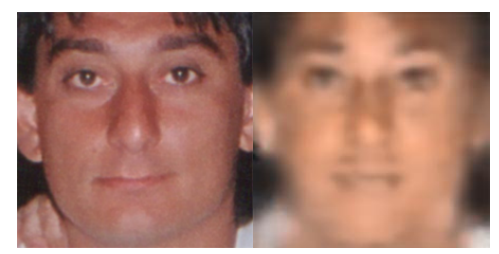

Slika 4.19: Vhodna slika (levo) ter generirana slika (desno) pogojnega avtoenkoderja.

\subsection{Metrike}

Za potrebe prvega testa, kjer kažemo tako dejanske kot naključno izbrane pare definiramo:

- $\mathbf{T P}$ - dejanski pari, kjer je oseba označila, da sta osebi na sliki enaki.

- $\mathbf{T N}$ - nepravilni pari, kjer je oseba označila, da osebi na sliki nista enaki.

- FP - nepravilni pari, kjer je oseba označila, da sta osebi na sliki enaki. 
- FN - dejanski pari, kjer je oseba označila, da osebi na sliki nista enaki.

S pomočjo teh vrednosti lahko definiramo standardne metrike za evalvacijo klasifikacije:

- Natančnost (angl. precision) definiramo kot $\frac{T P}{T P+F P}$.

- Priklic (angl. recall) definiramo kot $\frac{T P}{T P+F N}$.

\subsection{Evalvacija rezultatov}

Najboljše rezultate smo dobili s pomočjo nasprotniškega avtoenkoderja. Če si pogledamo grafe poteka učenja na sliki 4.20 vidimo, da tako generator kot MSE konvergirata proti določeni vrednosti. Napaka generatorja pa se s časom rahlo povečuje. Najprej si poglejmo nekaj dobljenih vizualnih rezultatov na sliki 4.21, kjer se identiteta osebe precej ohrani, poleg tega pa se oseba tudi vidno postara.

Največja težava nastane pri vhodnih slikah, kjer nastopajo osebe z brki, brado ali očali, enega od primerov vidimo na sliki 4.22. V teh primerih naš model težko zazna obraz in generirane slike so popačene. To se zgodi predvsem zato, ker v učni množici ni dovolj fotografij oseb z brado in ostalimi dodatki, npr. očali.

Kljub temu da so vizualni rezultati na prvi pogled delovali zelo solidno, pa je evalvacija rezultatov pokazala velike pomanjkljivosti v naših rezultatih.

\section{Test z mešanimi pari}

V tabeli 4.2 vidimo rezultate prvega vprašalnika, kjer smo imeli tako pravilne kot naključne pare.

\begin{tabular}{|c|cccc|}
\hline & TP & TN & FP & FN \\
\hline Število & 101 & 227 & 83 & 202 \\
\hline
\end{tabular}

Tabela 4.2: Klasifikacijska tabela. 

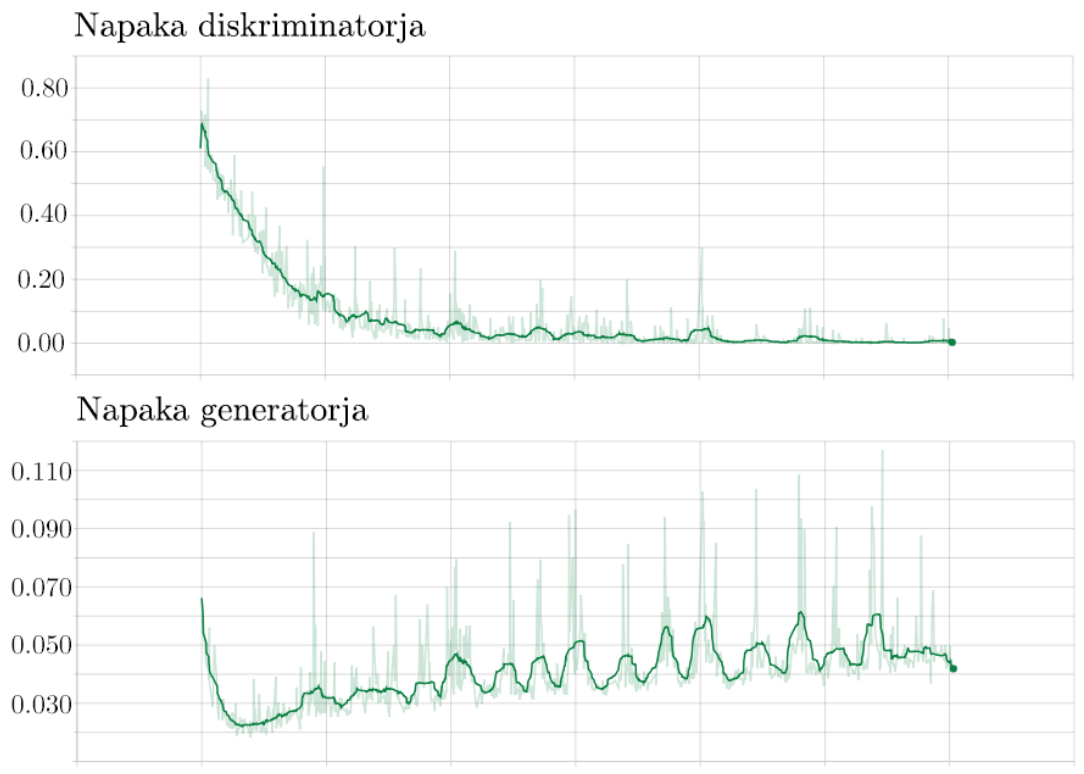

Srednja kvadratna napaka (MSE) med vhodno in izhodno sliko

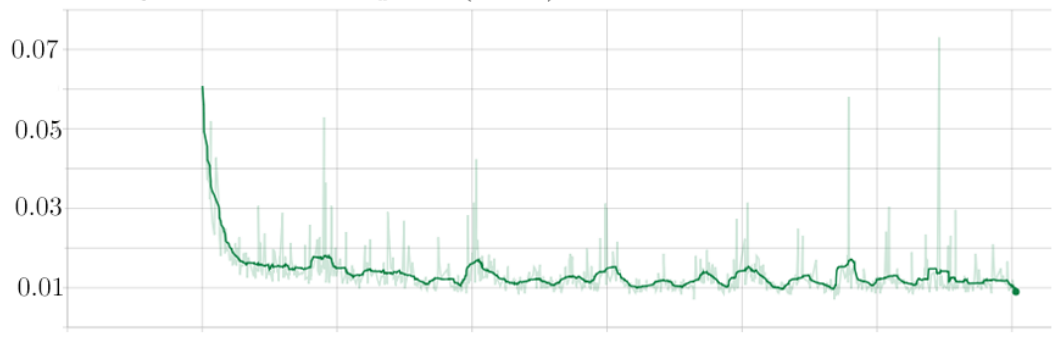

čas

Slika 4.20: Učenje nasprotniškega avtoenkoderja.

Največjo težavo predstavlja velika mera napačno negativno klasificiranih vzorcev. To nam pove, da nam identite ni uspelo pravilno ohraniti. Če pogledamo porazdelitev izbranih možnosti na grafu na sliki 4.23 vidimo, da imamo preveč odgovorov, ki navedejo, da osebi nista enaki.

Pri popolni metodi bi si želeli enakovredno število odgovorov za Osebi nista isti in za Osebi sta isti ter minimalno število odgovorov za Nisem prepričan. Izračunali smo tudi metriko natančnosti, za katero smo dobili vrednost 0,54 ter priklica, kjer smo dobili 0,33 . 


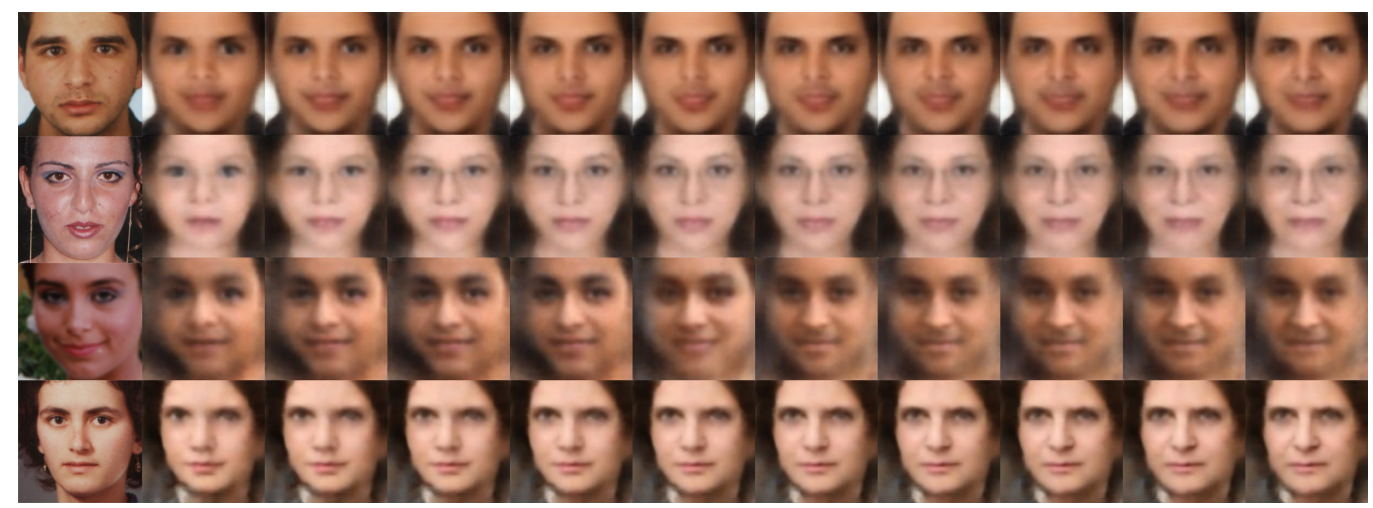

Slika 4.21: Obrazi ustvarjeni s pomočjo nasprotniškega avtoenkoderja.

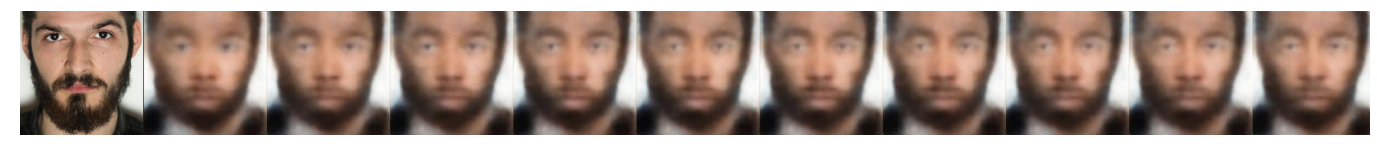

Slika 4.22: Rezultati pri staranju obraza z brado.

\section{Test z zgolj dejanskimi pari}

Zanimiva je primerjava z drugim testom, kjer so nastopali samo dejanski pari med referenčno sliko ter generirano sliko. Dobili smo porazdelitev, ki je vidna na sliki 4.24. Vidimo, da je v tem primeru manjši odstotek odgovorov Osebi nista isti, kar pomeni, da naša metoda vsaj delno deluje in ohrani identiteto. Pri drugem testu dobimo torej, da je 55,7 \% odgovorov Osebi nista isti, 28,5 $\%$ Osebi sta isti ter $15,8 \%$ Nisem prepričan.

Če to primerjamo z vrednostmi v enem od referenčnih člankov s podobnim protokolom [2] vidimo, da so naši rezultati slabši, saj so avtorji v tem članku dosegli $48 \%$ odgovorov Osebi sta isti. Velja omeniti, da se je naš protokol nekoliko razlikoval. V članku so avtorji vsaki osebi pokazali tri slike: generirano sliko, referenčno sliko, ki je bila vhod za generirano sliko ter sliko osebe pri cilji starosti. Menimo, da prikaz vhodne slike negativno vpliva na točnost evalvacije rezulatov, saj anketirancem omogoča primerjati vhodno sliko z referenčno starostno sliko, kar deluje sugestivno. 


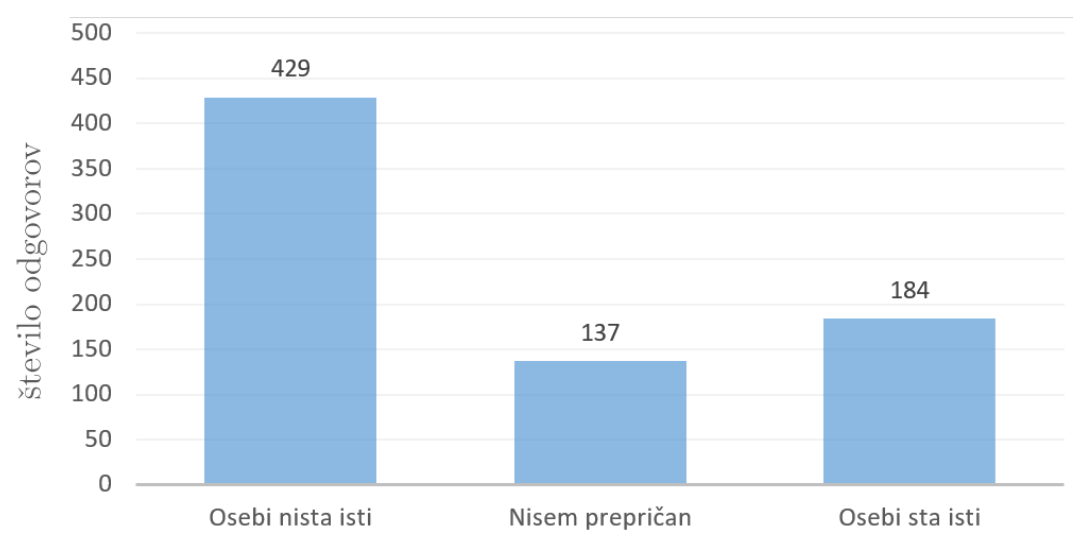

Slika 4.23: Porazdelitev odgovorov pri testu z mešanimi pari.

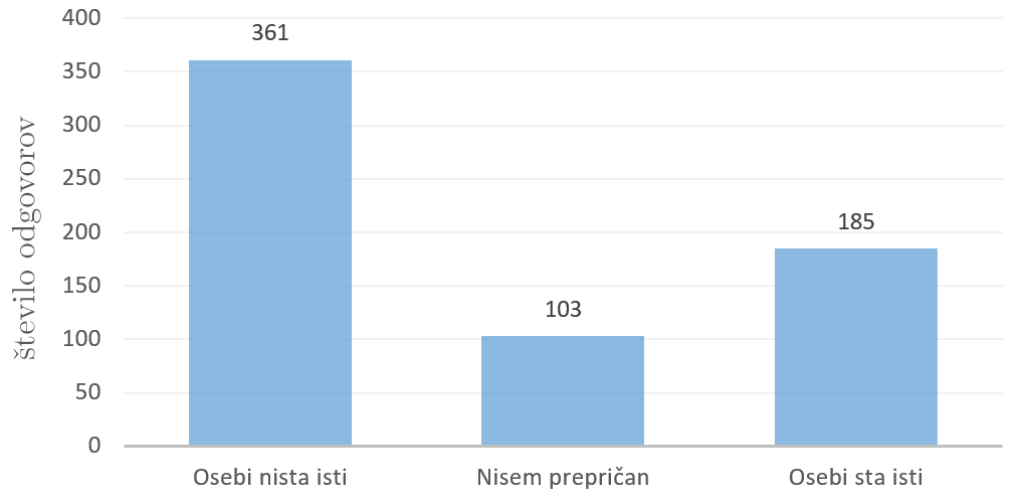

Slika 4.24: Porazdelitev odgovorov pri testu s samo dejanskimi pari.

\section{Test ocenjevanja starosti}

Poglejmo si še rezultate testa ocenjevanja starosti. Za vsako od slik so morali anketiranci izbrati, kateri starostni skupini mislijo, da pripada. Tudi tukaj smo prišli do presenetljivih rezultatov, saj so mladostnike starosti od (0-20) ljudje večkrat klasificirali v starosti med 20 in 40 let. Če primerjamo dejansko starostno porazdelitev na sliki 4.25 in jo primerjamo s porazdelitvijo starosti na sliki 4.26, ki so jih izbrali ljudje, vidimo precejšnje odstopanje v mlajših kategorijah. Rezultati nakazujejo, da naš model slabo generira slike mlajših oseb. Kadar postavimo vse generirane slike ljudi v vrsto, kot to naredimo na sliki 4.21, potem precej lažje vidimo potek staranja. Kadar pa je oseba 


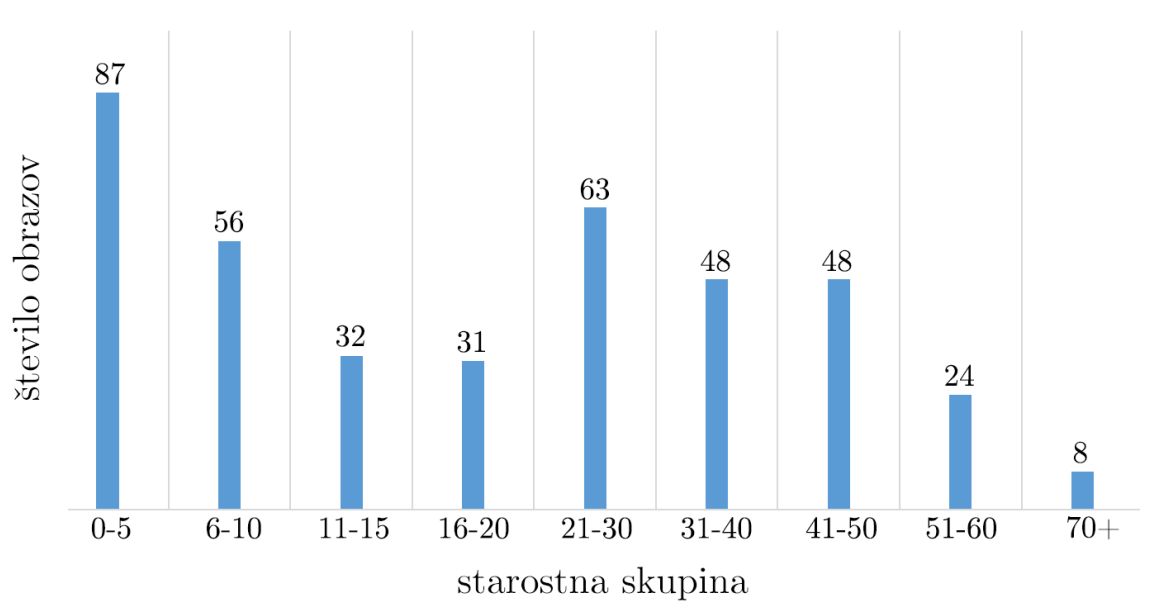

Slika 4.25: Porazdelitev dejanskih starosti.

soočena z določanjem starosti iz ene same generirane slike, rezultati pokažejo, da je to precej težje.

Poglejmo si še graf povprečne absolutne napake med dejansko in predvideno starostjo osebe na sliki 4.27 , ki je ločena glede na dejansko starost generirane osebe. Vidimo, da je napaka zelo velika $\mathrm{v}$ zgodnjih letih ter pri generiranju obrazov starosti večje od 60 let. 


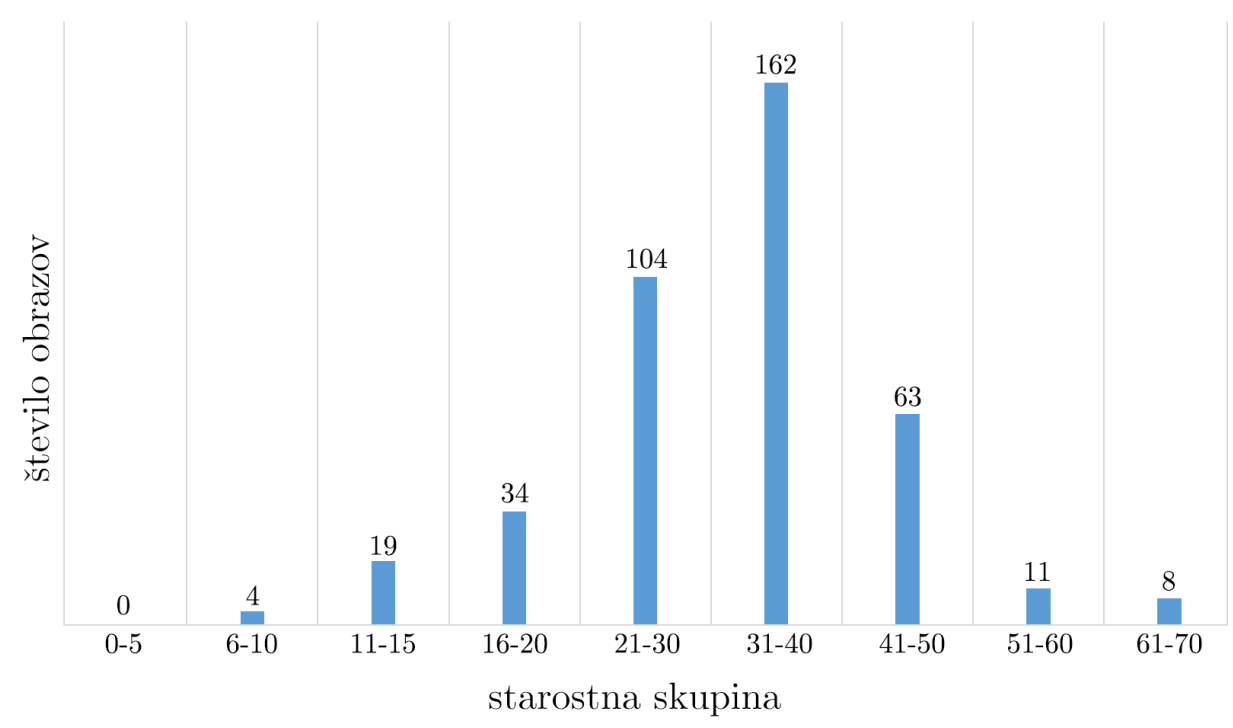

Slika 4.26: Porazdelitev predvidenih starosti.

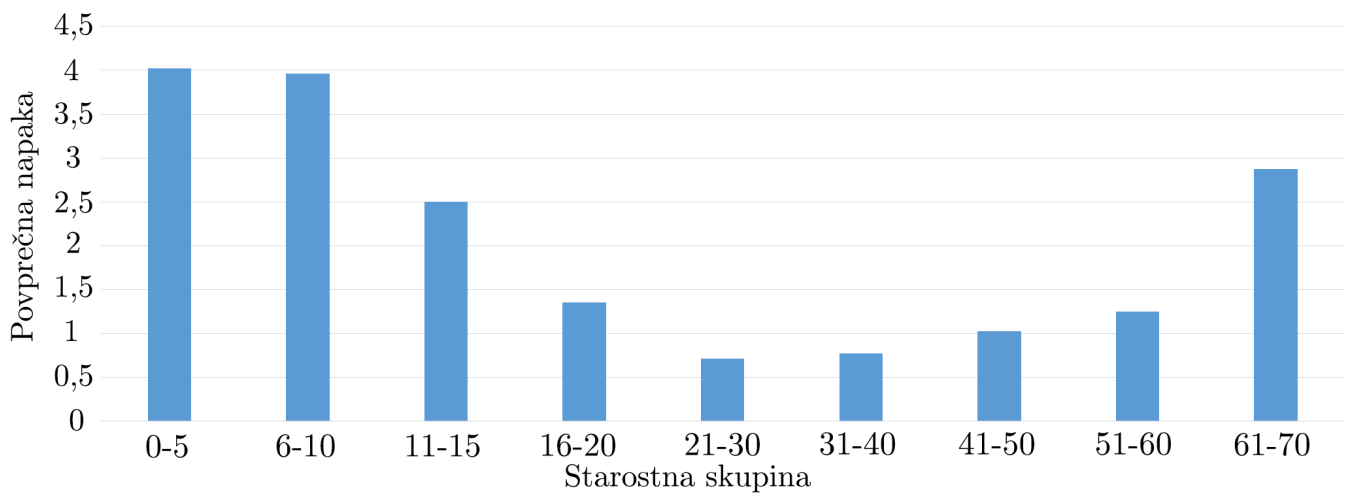

Slika 4.27: Porazdelitev povprečne absolutne napake pri starostnih skupinah. 


\section{Poglavje 5}

\section{Zaključek}

Z uporabo generativnih nevronskih mrež smo želeli razviti metodo, ki bi omogočala simuliranje staranja osebe glede na referenčno sliko. Implementirali smo klasične generativne modele ter poizkušali odkriti nove načine, ki bi pripomogli h kvalitetnejšim rezultatom.

Ugotovili smo, da je narava problema precej težka, saj je težko dobiti kompromis med staranjem osebe ter ohranjanjem njegove identite. Ta problem smo želeli rešiti z uvedbo dodatnega kritika v naše generativne modele, vendar naš pristop ni bil uspešen. Med delom smo se soočili s problemom pomanjkanja primerne podatkovne baze, ki bi kvaliteto rezultatov nedvomno povečala. Želeli bi si, da bi obstajala podatkovna baza, ki bi v enakovrednih intervalih spremljala potek staranja več oseb. To bi nam omogočilo kvalitetnejše pristope učenja nevronske mreže, ki se ne zanašajo na povprečno staranje populacije. Na težave smo naleteli tudi v evalvaciji rezultatov, saj na tem področju ni dogovorjenega standardnega pristopa. Metodologija, ki smo jo izbrali za evalviranje naših rezultatov, se nam je zdela smiselna, kljub temu da ima nekaj očitnih pomanjkljivosti. Največja od njih je dejstvo, da je težko določiti identiteto osebe iz ene same fotografije in pri različnih starostih.

Iz življenjskih izkušenj vemo, da na starih slikah velikokrat težko prepoznamo osebe, ki jih drugače dobro poznamo. Prav tako težko potrdimo ali sta osebi isti, če imamo na voljo le dve sliki. Na izgled osebe na fotografiji 
namreč močno vpliva veliko faktorjev, kot so naprimer osvetlitev, goriščna razdalja, obrazna mimika in podobno.

Želeli bi si pridobiti večjo natančnost pri ohranjanju identite, kar nam ni uspelo. Kot nadaljnje delo bi radi izpostavili možnost razvijanja modelov večje ločljivosti, ki bi zagotovo pomagali pri večji kvaliteti generiranih obrazov.

Raziskovanje generativnih modelov je zelo aktivno področje, zato menimo, da se bodo tehnike staranja obrazov razvijale v skladu z njim. Velja namreč, da je kvalitetna arhitektura generativne mreže temelj generiranja fotorealističnih slik obrazov. Ob prihodu novih arhitektur na področju generativnih modelov bi bilo smotrno izkoristiti njihove sposobnosti tudi na tem področju. Želeli pa bi si večji poudarek na ustvaranju javno dostopnih podatkovnih baz staranja, ki bi omogočile boljšo kvaliteto modelov.

Kot zaključek bi rad izpostavil, da nam zastavljenih ciljev ni uspelo doseči, saj smo si želeli večjo kvaliteto slik ter boljše ohranjanje identitete. Upamo, da smo s tem raziskovalnim delom omogočili bralcem, da se s pomočjo naše raziskave lažje odločijo o potencialnih pristopih, kadar se želijo spopasti s tem problemom. 


\section{Literatura}

[1] G. Antipov, M. Baccouche, J.-L. Dugelay, Face aging with conditional generative adversarial networks, in: The IEEE International conference on Image processing (ICIP), 2017, pp. 2089-2093.

[2] Z. Zhang, Y. Song, H. Qi, Age progression/regression by conditional adversarial autoencoder, in: The IEEE Conference on computer vision and pattern recognition (CVPR), 2017.

[3] Apptly LLC., Oldify, http://www.oldify.net/ (2018).

[4] Pivi Co., Aging Booth, http://www.piviandco.com/apps/ agingbooth/ (2013).

[5] APRIL face aging software, https://aprilage.com/pages/april $\%$ C2\% AE-face-aging-software (2018).

[6] J. Xie, L. Xu, E. Chen, Image denoising and inpainting with deep neural networks, in: Advances in neural information processing systems (NIPS), 2012, pp. 341-349.

[7] P. Vincent, H. Larochelle, Y. Bengio, P.-A. Manzagol, Extracting and composing robust features with denoising autoencoders, in: Proceedings of the 25th international conference on Machine learning (ICML), 2008, pp. 1096-1103. 
[8] O. Shcherbakov, V. Batishcheva, Image inpainting based on stacked autoencoders, in: Journal of physics: Conference Series (JPCS), Vol. 536, 2014, p. 012020.

[9] I. Goodfellow, J. Pouget-Abadie, M. Mirza, B. Xu, D. Warde-Farley, S. Ozair, A. Courville, Y. Bengio, Generative adversarial nets, in: Z. Ghahramani, M. Welling, C. Cortes, N. D. Lawrence, K. Q. Weinberger (Eds.), Advances in neural information processing systems 27, Curran Associates, Inc., 2014, pp. 2672-2680.

[10] D. P. Kingma, M. Welling, Auto-encoding variational Bayes, arxiv preprint arXiv:1312.6114 (2013).

[11] J. M. Joyce, Kullback-leibler divergence, in: International encyclopedia of statistical science, Springer, 2011, pp. 720-722.

[12] W. K. Hastings, Monte carlo sampling methods using markov chains and their applications.

[13] A. Makhzani, J. Shlens, N. Jaitly, I. Goodfellow, Adversarial autoencoders, in: International conference on learning representations (ICLR), 2016 .

URL http://arxiv.org/abs/1511.05644

[14] Y. Fu, G. Guo, T. S. Huang, Age synthesis and estimation via faces: A survey, IEEE Transactions on pattern analysis and machine intelligence 32 (11) (2010) 1955-1976.

[15] T. F. Cootes, C. J. Taylor, D. H. Cooper, J. Graham, Active shape models-their training and application, Computer vision and image understanding 61 (1) (1995) 38-59.

[16] Z. Liu, Z. Zhang, Y. Shan, Image-based surface detail transfer, IEEE Computer graphics and applications 24 (3) (2004) 30-35. 
[17] Y. Fu, N. Zheng, M-face: An appearance-based photorealistic model for multiple facial attributes rendering, IEEE Transactions on circuits and systems for video technology 16 (7) (2006) 830-842.

[18] T. F. Cootes, G. J. Edwards, C. J. Taylor, Active appearance models, IEEE Transactions on pattern analysis \& machine intelligence (6) (2001) $681-685$.

[19] W. Wang, Z. Cui, Y. Yan, J. Feng, S. Yan, X. Shu, N. Sebe, Recurrent face aging, in: Proceedings of the IEEE conference on computer vision and pattern recognition (CVPR), 2016, pp. 2378-2386.

[20] R. Rothe, R. Timofte, L. Van Gool, Deep expectation of real and apparent age from a single image without facial landmarks, International Journal of Computer Vision 126 (2-4) (2018) 144-157.

[21] A. Radford, L. Metz, S. Chintala, Unsupervised representation learning with deep convolutional generative adversarial networks, in: International conference on learning representations (ICLR), 2016.

URL https: //arxiv.org/abs/1511.06434

[22] F. Schroff, D. Kalenichenko, J. Philbin, Facenet: A unified embedding for face recognition and clustering, in: Proceedings of the IEEE Conference on computer vision and pattern recognition (CVPR), 2015, pp. $815-823$.

[23] C. Zhu, R. H. Byrd, P. Lu, J. Nocedal, Algorithm 778: L-bfgs-b: Fortran subroutines for large-scale bound-constrained optimization, ACM Transactions on Mathematical Software (TOMS) 23 (4) (1997) 550-560.

[24] F. Chollet, et al., Keras, https://keras.io (2015).

[25] M. Abadi, A. Agarwal, P. Barham, E. Brevdo, Z. Chen, C. Citro, G. S. Corrado, A. Davis, J. Dean, M. Devin, S. Ghemawat, I. Goodfellow, A. Harp, G. Irving, M. Isard, Y. Jia, R. Jozefowicz, L. Kaiser, M. Kudlur, J. Levenberg, D. Mané, R. Monga, S. Moore, D. Murray, C. Olah, 
M. Schuster, J. Shlens, B. Steiner, I. Sutskever, K. Talwar, P. Tucker, V. Vanhoucke, V. Vasudevan, F. Viégas, O. Vinyals, P. Warden, M. Wattenberg, M. Wicke, Y. Yu, X. Zheng, TensorFlow: Large-scale machine learning on heterogeneous systems (2015).

URL https://www.tensorflow.org/

[26] M. Mirza, S. Osindero, Conditional generative adversarial nets, arxiv preprint arXiv:1411.1784 (2014).

[27] J. Duchi, E. Hazan, Y. Singer, Adaptive subgradient methods for online learning and stochastic optimization, Journal of machine learning research 12 (Jul) (2011) 2121-2159.

[28] M. Arjovsky, S. Chintala, L. Bottou, Wasserstein generative adversarial networks, in: International conference on machine learning (ICML), 2017, pp. 214-223.

[29] T. Tieleman, G. Hinton, Lecture 6.5-rmsprop: Divide the gradient by a running average of its recent magnitude, COURSERA: Neural networks for machine learning 4 (2) (2012) 26-31.

[30] A. Jaiswal, W. Abdalmageed, Y. Wu, P. Natarajan, Bidirectional conditional generative adversarial networks, arxiv preprint arXiv:1711.07461 (2017).

[31] J. Donahue, P. Krähenbühl, T. Darrell, Adversarial feature learning, in: International conference on learning representations (ICLR), 2017.

[32] K. Grm, V. Štruc, A. Artiges, M. Caron, H. K. Ekenel, Strengths and weaknesses of deep learning models for face recognition against image degradations, IET Biometrics 7 (1) (2017) 81-89.

[33] F. N. Iandola, S. Han, M. W. Moskewicz, K. Ashraf, W. J. Dally, K. Keutzer, Squeezenet: Alexnet-level accuracy with 50x fewer parameters and $<0.5$ mb model size, arxiv preprint arXiv:1602.07360 (2016). 
[34] O. M. Parkhi, A. Vedaldi, A. Zisserman, et al., Deep face recognition., in: British machine vision conference (BMVC), Vol. 1, 2015, p. 6.

[35] C. Szegedy, V. Vanhoucke, S. Ioffe, J. Shlens, Z. Wojna, Rethinking the inception architecture for computer vision, in: Proceedings of the IEEE Conference on computer vision and pattern recognition (CVPR), 2016, pp. 2818-2826.

[36] K. Simonyan, A. Zisserman, Very deep convolutional networks for largescale image recognition, in: International conference on learning representations (ICLR), 2015.

URL https://arxiv.org/abs/1409.1556

[37] UTKFace - Aicip, http://aicip.eecs.utk. edu/wiki/UTKFace (2017).

[38] D. E. King, Dlib-ml: A machine learning toolkit, Journal of machine learning research 10 (2009) 1755-1758.

[39] X. Hou, L. Shen, K. Sun, G. Qiu, Deep feature consistent variational autoencoder, in: The IEEE Winter conference on applications of computer vision (WACV), 2017, pp. 1133-1141.

[40] O. Russakovsky, J. Deng, H. Su, J. Krause, S. Satheesh, S. Ma, Z. Huang, A. Karpathy, A. Khosla, M. Bernstein, et al., Imagenet large scale visual recognition challenge, International journal of computer vision 115 (3) (2015) 211-252.

[41] M. J. Powell, A direct search optimization method that models the objective and constraint functions by linear interpolation, in: Advances in optimization and numerical analysis, Springer, 1994, pp. 51-67.

[42] J. A. Nelder, R. Mead, A simplex method for function minimization, The computer journal 7 (4) (1965) 308-313. 
[43] Y. Fu, T. M. Hospedales, T. Xiang, Y. Yao, S. Gong, Interestingness prediction by robust learning to rank, in: European conference on computer vision (ECCV), 2014.

[44] K. Ricanek, T. Tesafaye, Morph: A longitudinal image database of normal adult age-progression, in: 7th International conference on Automatic face and gesture recognition (FG), 2006, pp. 341-345.

[45] N. Srivastava, G. Hinton, A. Krizhevsky, I. Sutskever, R. Salakhutdinov, Dropout: a simple way to prevent neural networks from overfitting, The journal of machine learning research 15 (1) (2014) 1929-1958.

[46] A. Mordvintsev, C. Olah, M. Tyka, Inceptionism: Going deeper into neural networks, http://ai.googleblog.com/2015/06/ inceptionism-going-deeper-into-neural.html (2015). 